\title{
EFEITOS DO ULTRA-SOM DE BAIXA INTENSIDADE NA OSSEOINTEGRAÇÃO DE IMPLANTES DE TITÂNIO EM TÍBIA DE COELHO: \\ AVALIAÇÃO HISTOMORFOMÉTRICA E MECÂNICA
}

\author{
Antonio Renato Sanches Colucci
}

Dissertação apresentada ao Programa de Pós-Graduação Interunidades em

Bioengenharia - Escola de Engenharia de São Carlos, Faculdade de Medicina de Ribeirão Preto e Instituto de Química de São Carlos da Universidade de São Paulo para obtenção do título de Mestre em Bioengenharia.

ORIENTADOR: Prof. Dr. José Marcos Alves

São Carlos - SP

2002 
Aos queridos Aldo, Mirtes, Daniel e Laura; por seu carinho verdadeiro, irrestrito e eterno. 
Agradecimentos

À Fundação de Amparo à Pesquisa do Estado de São Paulo (FAPESP) pelo apoio financeiro através do "Programa de Auxílio individual à Pesquisa” (projeto número 01/02196-2).

Ao Prof. Dr. José Marcos Alves, pela amizade, confiança e orientação neste trabalho.

Ao Prof. Dr. Marcelo Giovanetti, pelas orientações iniciais para a realização deste trabalho.

Ao Prof. Dr. Bruno König Jr. pela longa amizade, orientação e presença, sempre que foi preciso.

Ao colega doutorando Marcelo Carbonari, pela indispensável ajuda na realização da análise histomorfométrica no Instituto de Ciências Biomédicas III - USP.

À todos (técnicos, amigos, ...) que direta ou indiretamente ajudaram na elaboração deste trabalho.

À Dra. Thaís Machado Martins, por todo o apoio e compreensão durante a fase de elaboração da pesquisa.

Aos meus pais, por todo apoio e dedicação, sem os quais, jamais teria me tornado a pessoa que hoje sou. 
SUMÁRIO

Lista de Figuras

Lista de Tabelas

i

Resumo

iv

Abstract

1. INTRODUÇÃO 01

2. OBJETIVO 04

3. REVISÃO DA LITERATURA 05

3.1 Efeitos do Ultra-Som de Baixa Intensidade em Tecido 05 Ósseo - Aplicações em Ortopedia

3.1.1 Introdução 05

3.1.2 Estudos em Animais 06

3.1.3 Estudos Clínicos - Tratamento de Pseudoartroses 08

3.1.4 Estudos Clínicos - Fraturas com Retardo de Consolidação 14

3.1.5 Estudos Clínicos - Fraturas Recentes 15

3.1.6 Mecanismos de Ação do Ultra-Som de Baixa Intensidade 17 em tecido ósseo

3.1.7 Impacto Econômico do Tratamento de Fraturas por Ultra- 20 Som

3.1.8 Estudos de Revisão Bibliográfica 21

3.1.9 Evolução do Hardware 21

3.2 Efeitos do Ultra-Som de Baixa Intensidade - Novas 23 Aplicações

3.3 Interação do Ultra-Som com Implantes Metálicos 24

3.3.1 Investigações sobre Alterações no Implante 24

3.3.2 Investigações sobre Osseointegração em Implantes 25

4. BIOLOGIA ÓSSEA NA IMPLANTODONTIA 27

$4.1 \quad$ Estrutura Óssea $\quad 27$

4.2 Osseointegração de Implantes 28

4.2.1 Processo da Osseointegração 28

4.2.2 Histórico da osseointegração de implantes 29 
5. MATERIAL E MÉTODO 36

5.1 Animais e Implantes 36

5.2 Grupos Experimentais $\quad 39$

$\begin{array}{lll}5.3 & \text { Cirurgia } & 40\end{array}$

5.4 Exame Radiográfico 43

$\begin{array}{lll}5.5 & \text { Tratamento por Ultra-som } & 43\end{array}$

5.6 Análise Histomorfométrica 45

5.7 Ensaios Mecânicos 52

5.7.1 Ensaio de Torque 53

5.7.2 Ensaio de Arrancamento 54

5.8 Análise Estatística 56

6. RESULTADOS 56

6.1 Ensaios mecânicos 56

6.1.1 Ensaio de Torque 56

6.1.2 Ensaio de Arrancamento 57

6.1.3 Análise Histomorfométrica 59

7. DISCUSSÃO 64

8. CONCLUSÃO 69

9. PROPOSTA DE TRABALHOS FUTUROS 70

10. REFERÊNCIAS BIBLIOGRÁFICAS 71 


\section{LISTADE TABELAS}

Tabela 5.1 - Grupos Experimentais $\quad 39$

Tabela 5.2 - Número de Implantes por Método de Avaliação $\quad 39$

Tabela 5.3 - Administração de tetraciclina 45

Tabela 5.4- Curva de calibração do motor BLM 600 para 54 mensuração do torque aplicado na remoção dos implantes

Tabela 6.1 - Torque de Desrosqueamento ( $\mathrm{Ncm}$ ) 57

Tabela 6.2 Tabela 6.2 - Análise Estatística / Torque de 58

Tabela 6.3 - Torque de Desrosqueamento $(\mathrm{Ncm}) \quad 58$

Tabela 6.4 - Ensaio de Força de Arrancamento (Kgf) 59

Tabela 6.5 - Análise Estatística / Força de Arrancamento (Kgf) 59

Tabela 6.6 - Análise Estatística / Força de Arrancamento (Kgf) 60

Tabela 6.7 - Análise histomorfométrica 61

Tabela 6.8 - Análise Estatística / Histomorfometria (Osso Não 61 Calcificado)

Tabela 6.9 - Análise Estatística / Histomorfometria (Osso 62 Calcificado)

Tabela 6.10 - Análise Estatística / Histomorfometria (Osso Não 62 Calcificado)

Tabela 6.11 - Análise Estatística / Histomorfometria (Osso Calcificado) 
LISTA DE FIGURAS

Fig. 2.1 - Alteração do formato das espiras para se obter melhor área de contato ósseo e distribuição de forças.

(catálogo da Biohorizons, EUA)

Fig. 2.2 - Implantes com superfície lisa (polida - A) e mistos (B), com superfície trabalhada (mais rugosa propicia melhor retenção do implante)

(catálogo da Neodent - Brasil)

Fig. $3.1-\quad 1^{\text {a }}$ geração de hardware clínico brasileiro, 1980

Fig. 3.2 - $\quad 1^{\text {a }}$ geração de hardware clínico norte-americano, 199422 (Exogen Inc, Piscataway, NJ, USA)

Fig. 3.3 - $\quad 2^{\mathrm{a}}$ geração de hardware clínico norte-americano 22 (Smith \& Nephew / Exogen, Memphis, TE, EUA)

Fig. 3.4 - $\quad 3^{\mathrm{a}}$ geração de hardware clínico norte-americano 22 (Smith \& Nephew / Exogen, Memphis, TE, EUA)

Fig. $3.5-\quad 4^{a}$ geração de hardware clínico norte-americano (Smith \& Nephew / Exogen, Memphis, TE, EUA)

Pig. 4.1 - Peca exposta no museu de arqueologia e etnologia
da Universidade de Harvard, Cambridge, 30 Massachusetts (Dentistry: an illustrated history, 1985 - Mosby)

Fig. 4.2 - Algumas das aplicações clínicas para reabilitação de pacientes com implantes de titânio aplicados à Odontologia (catálogo - Branemark)

Fig. 4.3 - Seqüência da Biologia da Osseointegração (Fonseca, 1996)

Fig. 4.4 - Seqüência de eventos no decorrer do tempo em relação à manutenção da osseointegração e reabsorção óssea

(Fonseca, 1996)

Fig. 5.1 - Implante dental comercial de titânio master screw ${ }^{\circledR}$ (Catálogo - Conexão)

Fig. 5.2 - Corte transversal da mandíbula com um implante de 37 titânio colocado (Catálogo - Biohorizons)

Fig. 5.3 - Exemplo de uso clínico do Implante master screw ${ }^{\circledR}$

Fig. 5.4 - Vista comparativa do implante de titânio em relação à 37 tíbia do coelho 
Fig. 5.5 - Corte transversal da tíbia de coelho com um implante 38 de titânio colocado ( A - sem coloração e B,C - com azul de toluídina)

Fig. 5.6 - Vista do fêmur e da tíbia do coelho 38

Fig. 5.7 - Vista da face medial da tíbia e do local que recebeu 38 os implantes

Fig. 5.8 - Distância entre os implantes 38

Fig. 5.9 - Seqüência padrão de perfuração óssea na realização 40 de implantes de titânio (Catálogo - Conexão Sistemas de Prótese - Brasil)

Fig. 5.10 - Área a ser operada na face medial da tíbia do coelho 41

Fig.5.11 - Anestesia infiltrativa para melhorar a hemostasia 41 intra-operatória

Fig. 5.12 - Incisão feita com lâmina 11, diretamente ao osso 41

Fig. 5.13 - Descolamento do periósteo 41

Fig. 5.14 - Perfuração com broca de $1.6 \mathrm{~mm}$ de diâmetro 41

Fig. 5.15 - Perfuração com broca de $2.0 \mathrm{~mm}$ de diâmetro 41

Fig.5.16 - Colocação de guia para correta distância e 42 paralelismo

Fig. 5.17 - Perfuração para segundo implante (broca de $1.6 \mathrm{~mm}$ ) 42

Fig. 5.18 - Perfuração final (broca de $3.0 \mathrm{~mm}$ ) 42

Fig. 5.19 - Implante de 3,75 X 8,5 colocado na face medial da 42 tíbia

Fig. 5.20 - Implante proximal colocado. 42

Fig. 5.21 - Implantes colocados, ainda com os montadores 42

Fig. 5.22 - Implantes sem os montadores 42

Fig. 5.23 - Implantes com os cover-screws 42

Fig. 5.24 - Sutura da área operada 42

Fig. 5.25 - Radiografia lateral dos implantes de 3,75 X 8,5 mm 43

Fig. 5.26 - Sinal elétrico que excita o transdutor ultra-sônico 44

Fig. 5.27 - Aparelho de ultra-som de baixa intensidade 44

Fig. 5.28 - Animal imobilizado com o transdutor colocado na 44 face medial da tíbia esquerda

Fig. 5.29 - Aplicação do ultra-som na face medial da tíbia 45 
esquerda

Fig. 5.30 - Blocos incluídos em metilmetacrilato com os dois 46 implantes inseridos

Fig. 5.31 - Desenho do corte do bloco com os implantes 47 colocados.

(Fonseca, 1996)

Fig. 5.32 - Blocos incluídos em metilmetacrilato sendo cortados 47

Fig. 5.33 - Máquina para polimento das lâminas 48

Fig. 5.33a - Display mostrando a quantidade do desgaste que é 48 realizado e quanto ainda falta.

Fig. 5.34 - Cortes das tíbias com os implantes

A - Corte antes de preparo da lâmina final.

B - Corte pronto e polido para estudo de fluorescência

Fig. 5.35 - Vista de uma lâmina sendo estudada sob 49 Fluorescência

Fig. 5.36 - Vista da histologia através de fluorescência. 0 tom laranja, presente em pequena quantidade, evidencia o acúmulo de tetraciclina nos tecidos ao redor do implante

Fig. 5.37 - Regiões escolhidas para a análise histomorfométrica $\mathbf{5 0}$

Fig. 5.38 - Histologia através de campo claro, com coloração de 51 azul de toluidina $(A-4 X)-(B-10 X)$

Fig. 5.39 - Imagem adquirida pelo software, sendo submetida a 52 marcação das cores para estudo histomorfométrico.

Fig. 5.40 - Imagem com as cores marcadas: vermelho para osso não calcificado, amarelo para osso calcificado e verde para áreas de artefato ou espaços vazios na lâmina.

Fig. 5.41 - Testes de torque e arrancamento.

Fig. 5.42 - (A ) - Motor cirúrgico BLM 600 Plus para o teste de torque dos implantes; ( B ) adaptador sobre 0 implante e o contra-ângulo em utilização (contraângulo Kavo 120:1)

Fig. 5.43 - Máquina Instron com o dispositivo desenvolvido para 55 o arrancamento dos implantes

Fig. 5.44 - Dispositivo para o arrancamento dos implantes 


\section{RESUMO}

O efeito do ultra-som de baixa intensidade no reparo ósseo tem sido investigado em experimentos animais e clínicos no Brasil e exterior. Essas investigações resultaram em uma tecnologia não invasiva para o tratamento de fraturas aprovada pela Agência Nacional de Vigilância Sanitária (Brasil) e pelo Food and Drug Administration (FDA - EUA). Os resultados obtidos no tratamento de fraturas motivaram investigações sobre os efeitos do mesmo ultra-som na osseointegração de implantes metálicos (EUA).

Neste estudo foram utilizados 18 coelhos da raça Nova Zelândia, com peso entre 2,5 e 3,0 kg. Em cada tíbia foram inseridos 2 implantes de titânio de uso comercial em odontologia com superfície tratada por subtração ácida e com dimensões de $3,75 \mathrm{~mm}$ X $8,5 \mathrm{~mm}$. Os implantes da tíbia esquerda foram tratados por ultra-som de baixa intensidade por 20 minutos diários, durante 3,5 e 7 semanas. Os da tíbia direita foram usados como controle. A osseointegração nos implantes foi avaliada por testes mecânicos e histomorfométricos.

Os implantes tratados por ultra-som apresentaram em regiões ao redor das espiras superiores, após 3 e 5 semanas, maior quantidade de osso calcificado que nos implantes não tratados. Não houve significância estatística na quantidade de osso calcificado nas espiras de ambos os grupos após 7 semanas. 
As espiras de ambos os grupos, tratados e não-tratados, em contato com o osso cortical da tíbia, foram totalmente preenchidas por tecido ósseo após 3,5 e 7 semanas da sua colocação.

Os ensaios mecânicos de torque por desroqueamento e força de arrancamento não detectaram diferença na resistência mecânica entre implantes tratados e não-tratados por ultra-som após 3, 5 e 7 semanas. A resistência mecânica apresentada pelos testes mecânicos nesta investigação parece ser dependente do preenchimento total ou parcial das espiras dos implantes e não da quantidade de tecido ósseo calcificado presente.

Palavras-chave: ultra-som; implantes dentais; osseointegração. 


\section{ABSTRACT}

The low intensity ultrasound effect in bone repair has been investigated in animal and clinical experiments in Brazil and other countries. The result of these investigations was the development of a non-invasive technology for treating fractures which has been approved by FDA (USA) and by an agency (ANVISA) of the Brazilian Ministry of Health. The success in treating fractures motivated studies on the effects of the same ultrasound on bone ingrowth into metallic implants.

In this study two commercial titanium dental implants (STE) with $3,75 \mathrm{~mm} \times 8,5 \mathrm{~mm}$ were inserted bilaterally in the tibia of New Zealand rabbits $(n=18)$ weighing between $2.5-3.0 \mathrm{~kg}$. The implants in the left tibia were subjected to $\mathbf{2 0}$ minutes daily ultrasound treatment for 3,5 and 7 weeks. The implants in the right tibia served as a control. The osseointegration in the implants was analysed by mechanical tests (torsion and pull-out) and histomorfometry.

The implants treated by ultrasound showed more calcified bone in its threads and surrounding areas after 3 and 5 weeks than nontreated implants. The difference in the amount of calcified bone was not statiscally significant in the treated and non treated implants after 7 weeks.

The area of treated and non-treated implants in contact with cortical bone was full filled with bone after 3, 5 and 7 weeks. 
Mechanical tests (torsion and pull-out) did not show differences statistically significant between treated and non-treated implants after 3,5 and 7 weeks. The mechanical resistance of the implants seems to be more dependent on the amount of bone in the implants threads than the amount of calcified bone existing in the threads and surrounding areas.

Key words: ultrasound; dental implants; osseointegration 
1. Introdução

Os efeitos do ultra-som de baixa intensidade na aceleração da consolidação óssea em fraturas foram amplamente investigados em experimentos animais (Duarte, 1977, 1983; Pilla et al. 1991) e clínicos (Xavier, 1983; Frankel, 1998) no Brasil e exterior. O Brasil é o berço destas investigações, que se iniciaram na década de 70 com o Prof. Dr. Luiz Romariz Duarte, docente do Departamento de Engenharia de Materiais da EESC-USP.

Seus experimentos originaram-se de uma interação com médicos ortopedistas da Santa Casa de Misericórdia de São Carlos. Eles buscavam soluções para problemas no uso de materiais de osteossínteses e próteses ortopédicas. $O$ seu prolongado estágio neste Hospital resultou na criação de uma tecnologia não invasiva para tratamento de fraturas.

A tecnologia foi aprovada pela FDA (EUA) em 1994 para uso em determinados tipos de fraturas recentes e em 2000 para o tratamento de fraturas com não união (pseudo-artrose). A técnica é hoje uma realidade clínica nos EUA, Japão e vários países da Europa. No Brasil o Ministério da Saúde, através da sua "Agência Nacional de Vigilância Sanitária" (ANVISA), aprovou em 2001 o uso da tecnologia (resolução $n^{\circ} 1554$ do D.O.U. de 27/9/01).

O sucesso no tratamento de fraturas por ultra-som resultou na investigação sobre o uso desta tecnologia na osseointegração de 
implantes metálicos porosos para uso em ortopedia (Tanzer, 1996 e 2001). Os resultados das investigações de Tanzer et al. $(1996,2001)$ motivaram o estudo aqui descrito sobre os efeitos do ultra-som na osseointegração de implantes comerciais de titânio para reabilitação oral. Estes Implantes, para serem utilizados na reabilitação oral, necessitam da aceitação e trabalho de reparação do organismo ao redor de sua estrutura. Desse modo o osso, na fase de reparo da agressão sofrida para a colocação destes cilindros de titânio, deve ter a maior interface de contato possível com a sua superfície, permitindo assim o que se denomina de osseointegração. Para isto, normalmente o osso acaba por penetrar nas espiras das roscas dos implantes, tornando-os literalmente retidos no osso circundante.

O conceito de osseointegração está bem estabelecido na Odontologia, mas buscas constantes e estudos na área da integração tem sido amplamente realizados mundo afora para verificar, qualificar e quantificar, como e porque a integração ocorre e as formas de melhorála. As pesquisas, porém, normalmente estão voltadas para a estrutura dos implantes (tipos de superfície, área de contato com o osso, materiais de revestimento e desenhos anatômicos), como esquematizado nas figuras 2.1 e 2.2 .
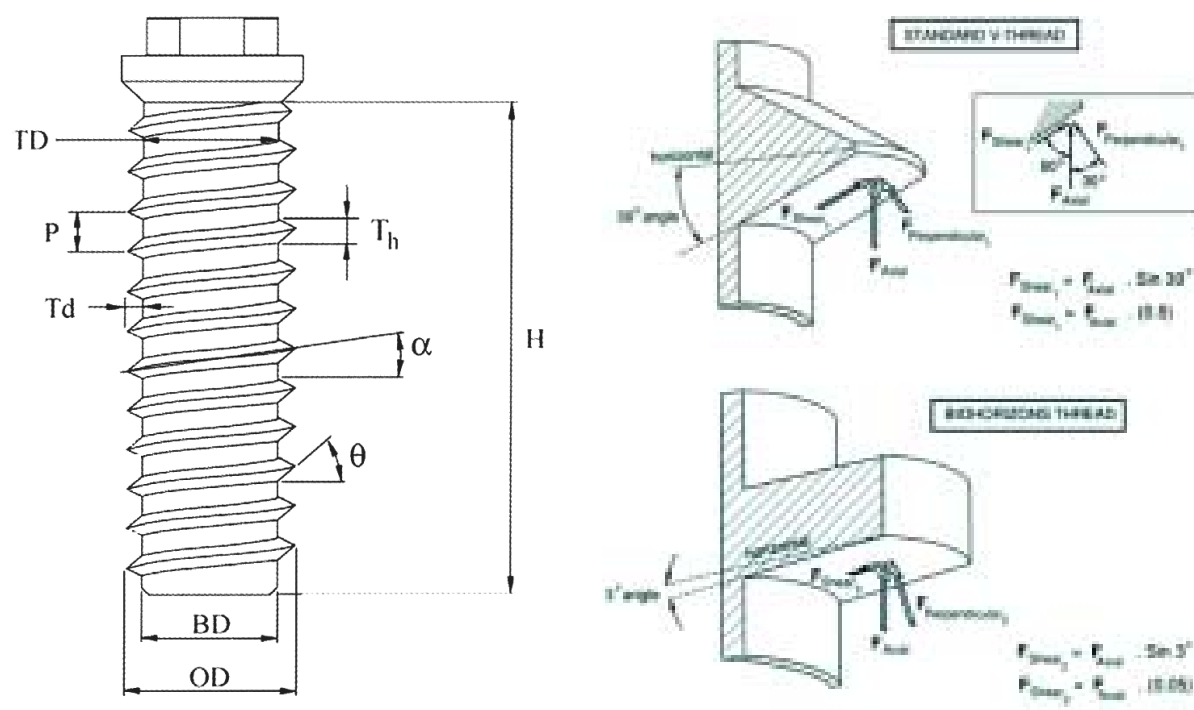
Fig. 2.1 - Alteração do formato das espiras para se obter melhor área de contato ósseo e distribuição de forças.

(catálogo da Biohorizons, EUA)

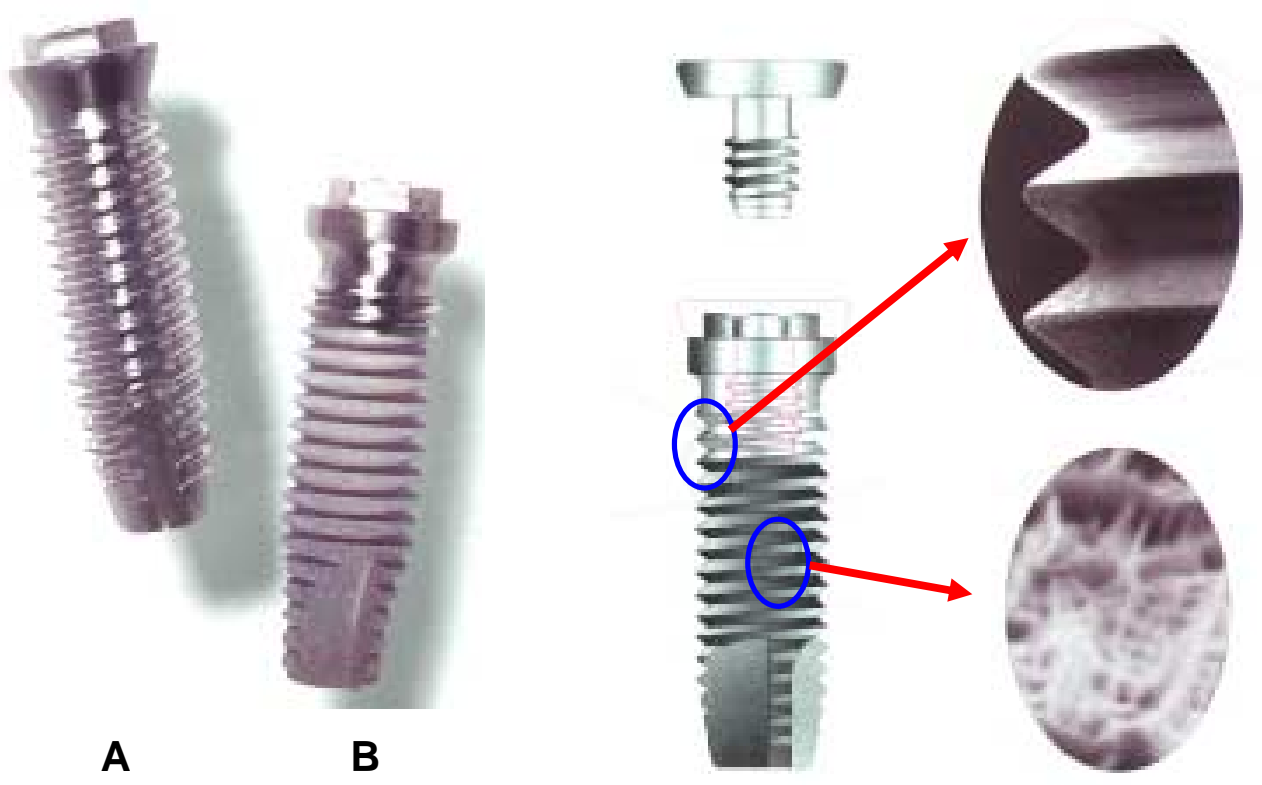

Fig. 2.2 - Implantes com superfície lisa (polida - A) e mistos (B), com superfície trabalhada (mais rugosa - propicia melhor retenção do implante)

(catálogo da Neodent - Brasil)

A maioria das pesquisas relacionadas a ação de agentes físicos externos sobre o reparo ósseo se concentram nos efeitos sobre 0 tecido. Poucos estudos investigaram a interação destes agentes com os implantes metálicos. 
2. Objetivo

O objetivo deste estudo é expandir o campo das investigações sobre os efeitos do ultra-som de baixa intensidade. Foram avaliados seus efeitos na qualidade e quantidade de osso neoformado na região intimamente ligada a implantes dentais de titânio com superfície tratada por subtração ácida.

Há um relevante interesse clínico na comprovação da melhoria da osseointegração destes implantes, o que resultaria na diminuição do tempo de tratamento em implantodontia. 
3. Revisão da Literatura

3.1 Efeitos do Ultra-Som de Baixa Intensidade em Tecido Ósseo Aplicações em Ortopedia

\subsubsection{Introdução}

O ultra-som vem sendo utilizado há anos na medicina em aplicações para cortes cirúrgicos (intensidades muito elevadas de 5 a $100 \mathrm{~W} / \mathrm{cm}^{2}$ ), aplicações convencionais fisioterapêuticas em tecidos e músculos (intensidades relativamente elevadas de 0,5 a $3 \mathrm{~W} / \mathrm{cm}^{2}$ ). Estas aplicações alcançam os seus resultados biológicos por meio de um aumento considerável na temperatura do tecido exposto. Por outro lado, as aplicações de diagnóstico através da imagem, como sonogramas fetais, mostram-se muito seguras pois não são de natureza térmica e utilizam intensidades muitos mais baixas, situada entre 0,001 à $0,05 \mathrm{~W} / \mathrm{cm}^{2}$ (Ziskin, 1989).

A técnica de ultra-som pulsado de baixa intensidade (SAPHS) utiliza uma intensidade de $0,03 \mathrm{~W} / \mathrm{cm}^{2}$ correspondente ao intervalo de procedimentos seguros de diagnóstico. 0 ultra-som de baixa intensidade produz forças micro-mecânicas no sítio da fratura através de ondas de pressão acústica. Vários investigadores discutiram a resposta óssea às forças mecânicas fisiológicas, incluindo a estimulação da atividade vascular (Wolff, 1892; Rubin, 1984; Goodship et al., 1985; Wallace, 1994). 


\subsubsection{Estudos em Animais}

Duarte (1977, 1983), em um estudo pioneiro com animais, foi o primeiro a demonstrar que a terapia de pulsos por ultra-som de baixa intensidade poderia afetar a consolidação de fraturas provocando um aumento significativo do calo ósseo. Ao pesquisar na literatura as propriedades elétricas do tecido ósseo (Fukada, 1957), particularmente a piezoeletricidade, Duarte decidiu investigar o uso do ultra-som de baixa intensidade na consolidação de fraturas ósseas experimentais em coelhos. Essa investigação foi o tema da sua tese de livre-docência. Duarte relatou dois estudos com coelhos. No primeiro foi produzida uma osteotomia bilateral da tíbia e no segundo um defeito bilateral na forma de furo em uma das corticais do fêmur. Em ambos os estudos foi estabelecido um grupo de animais controle e um grupo tratado, sendo que neste foi utilizada a estimulação ultra-sônica de baixa intensidade. Análises qualitativas (histologia e radiografia) e quantitivas (medida da área do calo formado) comprovaram uma significativa aceleração da regeneração nos dois estudos.

A evidência de que o ultra-som pulsado de baixa intensidade não apenas exerce influência positiva na quantidade de calo, como também aumenta significativamente a resistência mecânica e rigidez do calo foi observada em outro estudo (Pilla et al., 1990, 1991). Este estudo com controle placebo sobre osteotomia bilateral da fíbula em coelhos, relatou um aumento estatisticamente significativo na resistência de osteotomia tratada com SAFHS em comparação com o lado placebo do 14ํ dia até o 23ำ dia pós-operatórios. O lado tratado com ultra-som atingiu níveis de resistência equivalentes à do osso intacto dentro de 17 dias (67\% mais resistente do que o controle contralateral neste dia) se comparado com 28 dias para o lado placebo (um tempo de cura de osteotomia 1,6 vezes mais rápido no lado tratado com ultra-som). 
Outro estudo também comprovou o aumento da resistência mecânica em um modelo de fratura femoral em ratos (Wang et al., 1994). Foram induzidas fraturas fechadas bilaterais do eixo femoral em 22 ratos Long-Evans machos. As fraturas foram estabilizadas com um fio de Kirschner de 1,14 × $26 \mathrm{~mm}$, que serve como uma haste intramedular, inserida através de uma incisura intercondiliana no canal intramedular.

O ultra-som foi aplicado ao membro de 16 animais durante 15 minutos nos 14 primeiros dias do pós-operatório. Os membros tratados receberam um pulso de ondas senoidais de $1,5 \mathrm{MHz}$ ou $0,5 \mathrm{MHz}$ durante $200 \mu$ s repetidas com uma freqüência de $1,0 \mathrm{kHz}$ com uma média espacial e de intensidade temporal de $30 \mathrm{~mW} / \mathrm{cm}^{2}$.

O membro contralateral de cada animal serviu como controle não tratado. Seis animais com fraturas e seis animais sem fraturas receberam um falso tratamento por ultra-som para controle dos efeitos da anestesia e da manipulação.

O reparo da fratura foi avaliado no $21^{\circ}$ dia pós-operatório por radiografia, teste mecânico de torção e histologia. Cinco das 16 fraturas tratadas com ultra-som apresentaram eliminação do traço da fratura em radiografias, o que não ocorreu em nenhum dos 28 controles. A média do torque máximo das fraturas tratadas com qualquer um dos dois sinais foi superior em $22 \%$ à obtida nos controles contralaterais $(p<0,05)$. A rigidez das fraturas tratadas foi significativamente maior que os controles em animais tratados com 0 sinal de $1,5 \mathrm{MHz}(p<0,02)$. $O$ falso tratamento não afetou o nível de reparo no grupo controle.

O efeito estimulador do ultra-som no reparo de fraturas não foi inibido pela presença de um dispositivo interno metálico de fixação e a 
histologia mostrou-se normal, exceto pela ossificação endocondral mais avançada e intervalos menores entre os cotos ósseos nos membros estimulados. Estes resultados indicam que pulsos de ultrasom de baixa intensidade com $0,5 \mathrm{MHz}$ ou $1,5 \mathrm{MHz}$ podem acelerar com segurança 0 reparo de fratura dentro de 21 dias neste modelo altamente controlado com fixação metálica sendo que o processo de reparo foi melhor com 1,5 $\mathrm{MHz}$.

Azuma et al., (2001), investigou quatro diferentes períodos de tratamento de fraturas com ultra-som de baixa intensidade $e$ demonstrou que a consolidação foi acelerada em todos os grupos de estudo, independentemente do período ou duração do tratamento.

Mayr et al., (1999), demonstraram que o ultra-som de baixa intensidade acelerava significativamente a maturação da regeneração por distração do calo em um modelo animal com carneiros.

Shimazaki et al., em trabalho a ser publicado no Journal of Bone and Joint Surgery, relataram efeitos similares com distração do calo em um modelo com coelhos. Yang et al., (1996), relataram um aumento significativo do gene mRNA aggrecan, gene este, relacionado à cartilagem, e um aumento não significativo de $\alpha 1$ (II) procolágeno mRNA no calo ósseo.

\subsubsection{Estudos Clínicos - Tratamento de Pseudoartroses}

O uso clinico da terapia de ultra-som pulsado de baixa intensidade foi relatado pela primeira vez em estudo brasileiro com um índice de sucesso de $64 \%$ em uma série de 28 fraturas não consolidadas (Xavier, 1987, 1983). Duarte et al., (1996), relataram um índice de sucesso de $\mathbf{8 5 \%}$ em $\mathbf{3 8 0}$ fraturas não consolidadas com um tempo médio de consolidação de 77 dias utilizando ultra-som com 
pulsos de baixa intensidade. Os seguintes Índices de sucesso em tratamento de pseudoartroses com ultra-som de baixa intensidade foram observados em outros estudos: $83 \%$ (Strauss et al., 1996), $80 \%$ (Frankel, 1996), 80\% (Mayr e Ruter, 1998). Mayr et al., (1997), não encontraram diferença no índice de sucesso de $93 \%$ em seu tratamento clínico de pseudoartroses com ultra-som de baixa intensidade quando comparadas aos índice de sucesso de $83 \%$ conseguidas com dados similares no registro de prescrição nos Estados Unidos em Janeiro de 1997.

Meani e Romano, (1997), avaliaram o efeito da terapia com ultrasom em pseudoartroses infectadas da tíbia na presença de osteossínteses e obtiveram um índice de sucesso maior que $95 \%$. Eles constataram que seus resultados eram comparáveis aos índices de sucesso do registro nos EUA relativo às fraturas de tíbia não consolidadas e infectadas que tiveram um índice de sucesso de $89 \%$.

Em um outro estudo, Mayr et al., (1999), relataram os resultados de três casos complicados de fraturas não consolidadas tratadas por ultra-som de baixa intensidade. Os resultados comprovam claramente a eficácia desta terapia nestes casos.

Mayr et al., (2000), demonstraram uma redução de 5 a $10 \%$ no índice de sucesso em pacientes que usavam bloqueadores de canais de cálcio, antiinflamatórios não esteroidais (AINES) e esteróides, além de pacientes sob tratamento renal e com insuficiência vascular no local da fratura não consolidada. Os fumantes também apresentaram percentuais de índices de sucesso muito abaixo do valor total de $86 \%$ alcançado nas 366 fraturas não consolidadas tratadas com ultra-som de baixa intensidade. 
Romano et al., (1999), apresentaram resultados de quinze pacientes com casos complicados de fraturas não consolidadas da tíbia (10), fêmur (2), úmero (1), tornozelo (1) e ulna (1). Eles comunicaram um índice de sucesso de $90 \%$ nos casos concluídos, e os cinco casos restantes demonstravam sinais de evolução da cura.

Heppenstall et al., (1999), comunicaram um índice de sucesso de $82 \%$ em 429 pseudoartroses com uma idade média de fratura de 658 dias (1,8 anos). A cura de uma fratura não consolidada foi alcançada após 168 dias em média. Frankel (1998) avaliou o índice de sucesso em fraturas não consolidadas em diversos locais do osso e relatou um índice de $70 \%$ no úmero, $86 \%$ no fêmur, $81 \%$ no metatarso, $96 \%$ no rádio, $86 \%$ no escafóide e $83 \%$ na tíbia. Relatou também que o tempo de cura variou de 118 dias para o rádio até 173 dias para o úmero.

Um estudo alemão e austríaco investigou a eficiência do ultrasom de baixa intensidade no tratamento de fraturas não consolidadas com uma idade média de 39 meses, dois procedimentos cirúrgicos anteriores com insucesso e um tempo médio de 24,2 meses do ultimo procedimento cirúrgico com insucesso (Gebauer et al., 2000). 0 ultrasom de baixa intensidade foi o único tratamento e o índice de sucesso foi de $85 \%$ (57 / 67). Resultados semelhantes foram obtidos em um estudo francês (Moyen et al., 2001) e em um estudo holandês (Nolte et al., 2001) com índices de sucesso de $89 \%$ e $86 \%$, respectivamente.

Nos Estados Unidos em um estudo de fratura não consolidada de tíbia, (Frankel et al., 1999) foi relatado o índice médio do tratamento de 174 fraturas não consolidadas de tíbia e tíbia/fíbula, com uma média de 2,2 procedimentos cirúrgicos com insucesso, e uma idade média de fratura de 23 meses desde o trauma inicial. O subconjunto de 131 fraturas não consolidadas de tíbia apresentou um índice de sucesso de $84 \%$ e as 43 fraturas não consolidadas de tíbia/fíbula um índice de $81 \%$. 
A classificação dos resultados segundo certas características do paciente e da fratura demonstraram que os fumantes tinham um índice de sucesso $22 \%$ menor que os não fumantes; as fraturas do eixo distal apresentaram o menor índice de sucesso com $79 \%$ sendo de $91 \%$ a de fraturas proximais não consolidadas. $O$ índice de sucesso variou com $o$ número de procedimentos cirúrgicos anteriores com insucesso sendo de $81 \%$ para um procedimento, e de $74 \%$ para três ou mais procedimentos. $O$ índice de sucesso foi menor nos casos em que a idade da fratura ultrapassou três anos do que nos casos em que passou-se menos de um ano da fratura, quando o índice foi de $92 \%$.

Lane et al., (1999), analisaram o registro de dados do período posterior a autorização da comercialização da tecnologia de tratamento de fraturas por ultra-som, até Janeiro de 1998, utilizando análise univariada e multivariada para determinar os fatores de risco que afetavam a consolidação de fraturas com idades menores que 181 dias. A análise mostrou que pacientes idosos, fraturas com tempo maior de ocorrência, hábito de fumar, obesidade, usuários de esteróide, com doença renal, e a existência de fratura de úmero são fatores que podem reduzir o índice de sucesso de consolidação.

Um suplemento do PMA (Pre Market Approval) nos EUA relata um estudo retrospectivo de um grupo de pacientes com pseudoartrose tratados com ultra-som de baixa intensidade na Alemanha e na Áustria (PMA, 2000; Gebauer et al., 2000). 0 estudo foi projetado de maneira que cada caso de pseudoartrose servia como seu próprio controle e o resultado de tratamento anterior com insucesso como controle, quando comparado ao ultra-som como sendo o único novo tratamento.

O critério primário de definição de casos de fratura não consolidada foi o tempo mínimo de nove (9) meses decorrido desde a 
fratura. Os casos de pseudoartrose que atendiam ao critério de um mínimo de 9 meses foram então classificados em duas categorias mutuamente exclusivas, caracterizadas pelas denominações de "grupo central" e "grupo não-central".

A categoria do grupo central exigia que os casos de pseudoartroses estivessem estabelecidas, sem intervenção cirúrgica no período de três meses antes do tratamento com o SAFHS, que tivessem concluído o tratamento, além do período mínimo de 9 meses a partir do trauma inicial.

A categoria do grupo não-central incluiu os casos que não podiam ser validados como pseudoartroses estabelecidas pelos investigadores principais, com procedimentos cirúrgicos dentro dos três meses antes do tratamento com o SAFHS, que tivessem concluído o tratamento, casos com dados incompletos e todos os casos com tratamento não concluído ( $1 \mathrm{com}$ morte, 2 de não cumprimento e 2 desistências), além do tempo mínimo de 9 meses a partir do trauma inicial.

Entre os excluídos, nos dois grupos, estão, gestantes, pseudoartroses da coluna ou do crânio, pseudoartroses relacionadas a tumores e pacientes que não conseguiram cumprir o programa de tratamento exigido.

Os seguintes aspectos, quanto a segurança e eficácia do tratamento, foram mencionados no suplemento:

a) Segurança: 
Não foram relatadas quaisquer reações adversas decorrentes do aparelho ou complicações médicas relativas ao uso deste aparelho durante o estudo clínico.

b) Eficácia:

A eficácia foi significativa quando comparada com os tratamentos anteriores com insucesso $(p=0,00001)$. Os casos concluídos apresentaram um índice de sucesso de $86 \%$ (64/74) com um tempo médio para consolidação da fratura de $163 \pm 9,4$ dias. A média do tempo de cura foi de 142 dias variando entre 53 e 375 dias. A idade média da fratura para os casos de cura no grupo central foi de $934 \pm$ 151,6 dias ou aproximadamente 3 anos, e a média da idade da fratura foi de 494 dias variando entre 257 e 601 dias. 0 subconjunto de casos concluídos do grupo central apresentou um índice de sucesso de $88 \%$ (36/41) que era semelhante ao subconjunto de casos concluídos no grupo não central com índice de sucesso de $85 \%$ (28/33).

Os índices de sucesso também foram sistematicamente semelhantes ao longo das variáveis de classificação, inclusive sexo e idade, exceto pelo decrescente índice de sucesso para fraturas não consolidadas do escafóide, que afetou a estratificação por osso, ossos longos comparados a outros ossos, e a categoria de idade da fratura (tempo desde a fratura inicial até o começo do tratamento com SAPHS) de mais de 5 anos (>1827 dias).

O índice de sucesso de $33 \%$ (2/6) de fraturas não consolidadas do escafóide pôde ser atribuída aos fracassos em quatro fraturas não consolidadas do escafóide, todos com mais de 10 anos de idade de fratura, tratando-se, portanto, de casos muito difíceis e complexos. Casos com a presença de metal durante tratamento com SAFHS, placas 
ou hastes-intramedulares, tiveram um índice de sucesso de $88 \%(21 / 24)$ e $100 \%(16 / 16)$, respectivamente.

Os resultados deste estudo clínico, pareado, de fraturas com pseudoartrose, demonstrou a segurança e eficácia do ultra-som de baixa intensidade no tratamento de pseudoartroses, inclusive nos casos de fraturas antigas de até 5 anos, mas sugere que pseudoartroses com idade de fratura superior a 5 anos podem apresentar uma resposta menor ao tratamento.

Dois estudos clínicos adicionais foram relatados neste PMA como dados de apoio ao estudo alemão. Estes estudos foram realizados nos Estados Unidos e na Holanda. No estudo nos Estados Unidos, foi mantido um arquivo do uso sob prescrição (Heppenstal et al., 1999). Os dados dos casos de pseudoartroses foram examinados e os detalhes de protocolo foram semelhantes para os critérios de inclusão/exclusão, projeto do estudo e medidas de eficiência. Ao invés de avaliações por pesquisadores independentes, este estudo utilizou a avaliação desses pesquisadores sobre uma pseudoartrose estabelecida no início do estudo, e o resultado de cura ou insucesso ao final de tratamento.

Nos Estados Unidos o grupo de tratamentos concluídos apresentou um índice de sucesso de 82\% (352/429). Quando comparamos este índice de sucesso com o tratamento anterior com insucesso, o resultado é estatisticamente significativo com $p=0,00001$ a favor dos resultados de tratamento com SAFHS. $O$ índice de sucesso de $80 \%$ (249/313) para o grupo central foi semelhante ao índice de $88 \%$ (103/116) para o grupo não-central. Os resultados de índice de sucesso foram sistematicamente semelhantes independente de variáveis de classificação, inclusive sexo e idade. 
Na Holanda foi conduzido um estudo idêntico ao estudo alemão (Nolte et al., 2001). Neste estudo, o resultado do índice de sucesso de tratamentos completos foi de $90 \%(27 / 30)$. Este índice de sucesso quando comparado com o tratamento anterior com insucesso foi estatisticamente significativo $\operatorname{com} p=0,00001$. 0 subconjunto do grupo central apresentou um índice de sucesso de $87,5 \%$ (21/24), semelhante ao índice de sucesso de $100 \%$ (6/6) para o subconjunto não-central. Os resultados de índice de sucesso foram sistematicamente semelhantes independente de variáveis de classificação, inclusive sexo e idade.

\subsubsection{Estudos Clínicos - Fraturas com Retardo de Consolidação}

Um estudo de Frankel (1998) relata índices de sucesso no tratamento de fraturas com retardo de consolidação, definidas pelo autor como sendo fraturas com idade entre 91 e 269 dias. Os índices de sucesso variaram de $82 \%$ à $97 \%$ e os sítios avaliados foram o fêmur, úmero, metatarso, rádio, rádio/ulna, escafóide, tíbia e tíbia/fíbula.

Em retardos de consolidação o estudo de Mayr, não encontrou diferença ao se comparar o seu índice de sucesso de $88 \%$ com o índice de sucesso de $90 \%$ nos Estados Unidos (Mayr et al., 1997).

Frankel e Mizuno, (2001), reportaram o acompanhamento dos resultados de tratamento de aproximadamente $\mathbf{5 0 0 0}$ casos de fraturas não consolidadas utilizando a terapia de ultra-som pulsado de baixa intensidade (índice de sucesso de $88 \%$ [4,404/4,999]). Eles avaliaram os resultados de estudos internacionais com controle auto-pareado nos Países Baixos (86\%), Alemanha (85\%), França (89\%) e Estados Unidos $(80 \%)$, bem como os resultados do registro de prescrição no Japão (91\%) e Estados Unidos (83\%). Estes registros de prescrição estratificados por osso mostraram resultados similares nos dois países, como por exemplo em fraturas de tíbia (85\% no Japão e $84 \%$ 
nos EUA), de úmero ( $85 \%$ no Japão e $83 \%$ nos EUA) e do fêmur ( $88 \%$ no Japão e $83 \%$ nos EUA).

\subsubsection{Estudos Clínicos - Fraturas Recentes}

Nos estudos clínicos com fraturas recentes o ultra-som foi usado diariamente em um período de tratamento de 20 minutos. A duração média do tratamento foi de 10 semanas (5-23 semanas) no estudo de diáfise tibial (Heckman et al., 1994) e de 9 semanas (6-11 semanas) no estudo de fratura de Colles (Kristiansen 1990, Kristiansen et al. 1997). Todas as fraturas em ambos os estudos clínicos foram tratadas com ultra-som de baixa intensidade dentro de 7 dias após a data da fratura.

Os dois estudos clínicos foram multicentros, prospectivos, com método duplo-cego e aleatório e controle via placebo. Os resultados de ambos os estudos revelaram que o tempo médio para cura de uma fratura (cura clínica e radiográfica) foi acelerado significativamente nos casos do grupo tratado de modo ativo, superando o grupo placebo (não tratado) com um fator de 1,6 (tíbia: ativos $=96$ dias $\pm 4,9$, placebo $=$ 154 dias $\pm 13,7$ com $P=0,0001$; fratura de Colles: ativos $=61$ dias $\pm 3,4$, placebo $=98$ dias $\pm 5,2$ com $P=0,0001$ ). Em cada estudo ocorreu uma aceleração de parâmetros importantes de consolidação radiográfica como as três corticais com união visível (o parâmetro principal de cura radiográfica) no estudo da tíbia, e na consolidação adiantada ou retardada do endósteo (trabecular) no estudo de Colles.

No estudo da tíbia, a taxa de formação de união corticais no grupo tratado com SAFHS foi acelerada desde o primeiro até o terceiro córtex com um fator de 5,6 em relação ao grupo não tratado (10 dias desde o primeiro até o terceiro córtex com união para o grupo tratado com ultra-som se comparado aos 56 dias para o grupo não tratado). 
Heckman et al., (1994), concluíram que o processo randômico criou dois grupos muito semelhantes de pacientes ativos e com placebo, possibilitando uma avaliação não tendenciosa do efeito do aparelho com tratamento ativo.

Kristiansen (1997), o principal pesquisador do estudo de Colles para a PMA, verificou que a consolidação inicial trabecular ocorria com uma velocidade $\mathbf{2 3} \%$ maior no grupo tratado (Colles: Ativos $=\mathbf{3 0}$ dias \pm 1,4; Placebo $=39$ dias $\pm 2,4$ com $P=0,001)$ e um fator de 2,5 (40\% para o grupo tratado com SAFHS comparado com $16 \%$ para o grupo não tratado) foi observado na análise da consolidação avançada do endósteo (trabecular) ou retorno da arquitetura normal óssea.

Mais recentemente, em estudo clínico prospectivo e aleatório de fraturas recentes de escafóide relatou uma consolidação $30 \%$ mais rápida no grupo tratado por ultra-som utilizando-se análise por tomografia computadorizada (Mayr et al., 2000). Em outro estudo prospectivo e aleatório, foi estudado o efeito do ultra-som de baixa intensidade no tratamento de fraturas de Jones mostrando uma aceleração significativa da consolidação nas fraturas tratadas por ultrasom (Strauss et al., 1999).

Cook et al., (1997), demonstraram uma redução significativa no tempo de consolidação em fraturas da tíbia e da distal do rádio em fumantes.

3.1.6 Mecanismos de Ação do Ultra-Som de Baixa Intensidade em Tecido Ósseo

Silva e Duarte, (1989), relataram que o fluxo iônico intracelular está relacionado a processos tais como a divisão, diferenciação celular ou síntese de matriz óssea. 0 campo piezoelétrico causado pelo ultra- 
som no tecido ósseo causa alterações nos canais ativos da membrana celular com uma conseqüente intensificação do metabolismo ósseo.

Estudos in-vitro demonstraram que o ultra-som pulsado de baixa intensidade afetou a atividade de mensageiros secundários em culturas de células ósseas, produziu um aumento significativo da absorção de cálcio em células mesenquimatosas isoladas bem como na diferenciação de culturas de células ósseas e de cartilagem. Foi demonstrado também um efeito sobre os níveis de adenilciclase e TGFB (Ryaby et al., 1991, 1992, 1989a, 1989b, 1990).

Wu et al., (1996), estimularam a expressividade do gene aggrecan em condrócitos cultivados usando ultra-som de baixa intensidade. Nolte et al., (1999), aplicaram o ultra-som de baixa intensidade até o $17^{\circ}$ dia em metatarsos de fetos de camundongos e constataram um aumento de $300 \%$ na zona de calcificação nos membros tratados em relação aos controles equivalentes.

Parvizi et al., (1997 e 1999), demonstraram que o ultra-som de baixa intensidade pode estimular a síntese de proteoglicanas em condrócitos de ratos medindo o aumento da expressividade do gene aggrecan.

Kokubo et al., (1999), demonstram que osteoblastos de camundongos expostos ao ultra-som de baixa intensidade aumentaram a produção de prostaglandina $E_{2}$ através da indução de mRNA cicloxigenase-2.

Em outro estudo, Parvizi et al., (2001), demonstraram que a ação sobre o cálcio foi necessária para a estimulação da síntese do gene aggrecan em condrócitos de rato. Ito et al., (2000), mostraram que o ultra-som de baixa intensidade e a 1,25 dihidroxivitamina $D_{3}$ pode 
acelerar a secreção de fatores de crescimento em osteoblastos e células endoteliais.

A exposição ao ultra-som de baixa intensidade aumenta a expressividade do gene aggrecan em um modelo de fratura de fêmur de rato (Yang et al., 1994, 1996). Os efeitos do estímulo por ultra-som sobre vários parâmetros da consolidação óssea após um ferimento diafisário foram avaliados em um modelo de fratura de fêmur.

Em 79 ratos Long-Evans machos com esqueletos maduros foram provocadas fraturas fechadas de femur, bilateralmente. As fraturas foram estabilizadas por um fio de Kirschner de 1,14 x $26 \mathrm{~mm}$, servindo como uma haste intramedular inserida através da incisura intercondiliana no canal intramedular. Apenas em uma das fratura, em cada animal, foi aplicado um sinal de ultra-som originado por um pulso de ondas senoidais de $0,5 \mathrm{MHz}$ durante $200 \mu \mathrm{s}$, repetido com uma freqüência de $1,0 \mathrm{kHz}$ com uma média espacial e de intensidade temporal de 50 ou $100 \mathrm{~mW} / \mathrm{cm}^{2}$. A fratura contralateral não foi exposta ao ultra-som e serviu como controle.

Três semanas após o ferimento realizou-se um teste mecânico de consolidação da fratura. Em fraturas tratadas com um sinal de ultrasom de $50 \mathrm{~mW} / \mathrm{cm}^{2}$, as médias do torque máximo e da rigidez à torção foram significativamente maiores nos casos tratados do que nos de controle. Nos animais tratados com um sinal de ultra-som de 100 $\mathrm{mW} / \mathrm{cm}^{2}$ as médias do torque máximo e da rigidez de torção foram maiores nos casos tratados do que nos de controle, mas os resultados não foram significativos.

A avaliação da expressividade do gene em fraturas tratadas com ultra-som revelaram um desvio na expressividade do gene aggrecan significativamente maior no $7^{\circ}$ dia e significativamente menor no $21^{\circ}$ 일 
dia. A expressividade do gene procolágeno $\alpha$ (II) foi alterada de forma semelhante, mas isto não foi significativo. A expressividade da codificação de genes para proteínas relacionadas aos ossos não revelou alterações entre os tratados com ultra-som e os controles. Este estudo confirma observações anteriores de que ultra-som específico aumenta a resistência mecânica do calo.

O efeito não é inibido pela presença de fixação metálica intramedular. Estes dados sugerem que o estímulo por ultra-som aumenta as propriedades mecânicas do calo da fratura através de estímulo da síntese prévia de proteínas da matriz extracelular na cartilagem, alterando possivelmente a maturação de condrócitos e a formação de osso endocondral.

A identificação de genes, expressa como uma função do tempo no calo de uma fratura em consolidação, estimulada por ultra-som foi investigada por Hadjiargyrou, (1997). Utilizando-se mRNA foram isolados certos genes que demonstram expressividade diferencial durante os estágios de cura de fraturas. Alguns dos genes identificados eram conhecidos e outros eram novos. 0 osteopontin, gene conhecido, e uma proteína da matriz óssea, foi supra-regulado por exposição ao ultra-som de baixa intensidade assim como a enzima fosfoglicomutase glicolítica (PGM), uma cDNA que desempenha papel primordial na síntese e utilização do glicogênio.

Entre os seis genes examinados, o tratamento de ultra-som parece elevar no calo da fratura, em relação aos controles, os níveis de osteopontin e a expressividade da PGM e diminuir ligeiramente os níveis de sialoproteína, proteína da matriz óssea bem conhecida.

Rawool et al., (1998), demonstraram que o ultra-som de baixa intensidade aumenta o fluxo sangüíneo no sítio da fratura, e 
consequentemente contribui com 0 fornecimento de substâncias importantes como citocinas e fatores de crescimento para o processo de consolidação.

Mcleod et al., (1995), investigaram as alterações in-vivo de temperatura em ossos e tecidos moles adjacentes, geradas por feixes de ultra-som pulsado. As alterações foram avaliadas em tíbia de peru $(\mathrm{N}=2)$ e em fêmur de cão ( $\mathrm{N}=4)$. A temperatura foi medida em sítios subcutâneos, intramusculares, superfícies periostais e endostais, e intracorticais, sob condições de controle de estabilidade e exposição ao ultra-som. Houve pequena alteração de temperatura dentro dos tecidos moles, inclusive, gordura, pele, músculo e superfícies de tecidos duros, ou seja, osso.

A temperatura em cada um dos sítios ósseos era mais baixa $(0,2$ à $0,485^{\circ} \mathrm{C}$ ) quando a haste intramedular era inserida com ou sem ultrasom. Esta observação sugere que a haste metálica atua como um dissipador de calor. 0 aumento de temperatura não ultrapassou um máximo de $0,425 \circ \mathrm{C}$ no córtex após uma exposição por 20 minutos ao ultra-som pulsado. Observou-se, com ultra-som, uma elevação de temperatura de $0,15^{\circ} \mathrm{C}$ na cavidade da medula na presença de uma haste intramedular e 0,0C sem a haste. Estes resultados comprovam que é mínima a influência do ultra-som na elevação de temperatura dos tecidos.

\subsubsection{Impacto Econômico do Tratamento de Fraturas por Ultra-Som}

Um estudo recente demonstrou os benefícios econômicos do tratamento de fraturas de tíbia com ultra-som de baixa intensidade (Heckman and Sarasohn-Kahn, 1997). No modelo usado no estudo, mostra-se que há uma economia de $\$ 13,000$ à $\$ 15,000$ por tratamento, 
considerando todos os custos associados e incluindo a remuneração de pessoal e da terapia pelo ultra-som de baixa intensidade.

\subsubsection{Estudos de Revisão Bibliográfica}

Uma revisão dos estudos animais e clínicos que utilizaram ultrasom de baixa intensidade na consolidação de fraturas incluiu os estudos in-vivo e in-vitro que investigaram os mecanismos biológicos afetados pelo estímulo ultra-sônico (Hadjiarjgyrou et al., 1998).

Rubin et al., (2000), revisaram dados substanciais de ciência básica que demonstram uma influência positiva do ultra-som de baixa intensidade nos três estágios do processo de consolidação (inflamação, reparo e remodelamento) devido ao aumento da atividade angiogênica, condrogênica e osteogênica.

Warden et al., (2000), em estudo de revisão sobre o efeito do ultra-som de baixa intensidade na aceleração da consolidação de fraturas, incluíram uma discussão sobre o tratamento de fraturas não consolidadas usando ultra-som de baixa intensidade e relataram um índice de sucesso de 83\% em 404 fraturas não consolidadas, sendo 691 dias o tempo médio das fraturas.

\subsubsection{Evolução do Hardware}

As figuras 3.1 à 3.5 mostram a evolução do equipamento de ultrasom de baixa intensidade utilizado no tratamento de fraturas. 


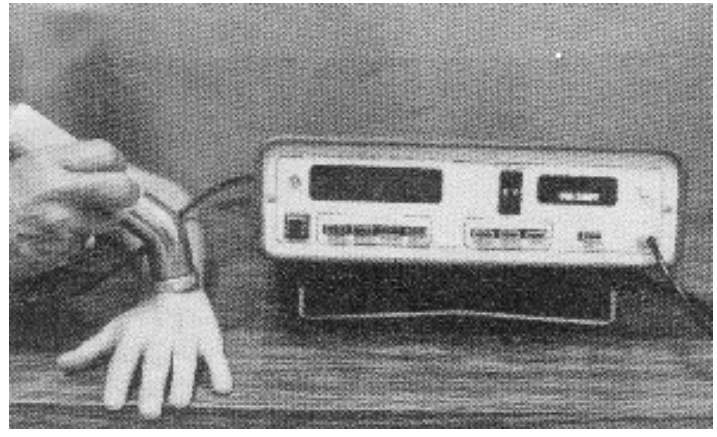

Fig. 3.1 $-1^{\mathrm{a}}$ geração de hardware clínico brasileiro, 1980

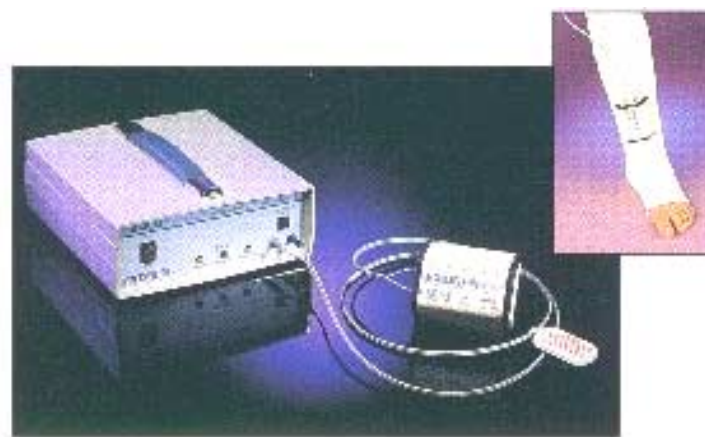

Fig. $3.2-1^{\text {a }}$ geração de hardware clínico norte-americano, 1994 (Exogen Inc, Piscataway, NJ, USA)

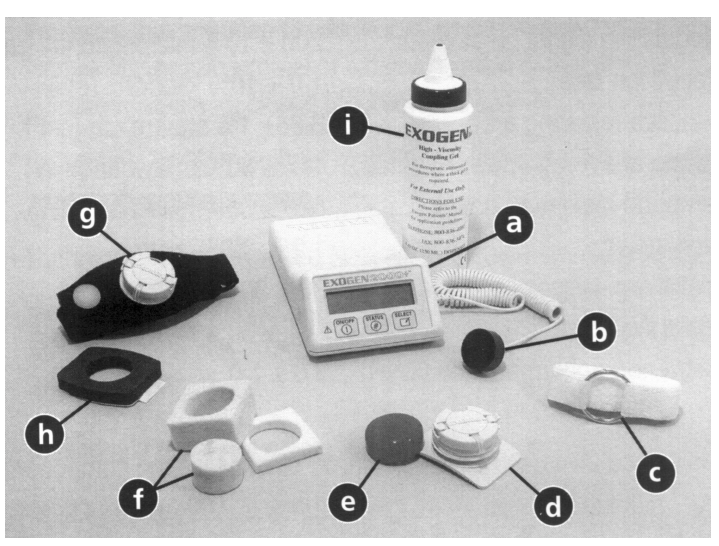

Fig. 3.4 - $3^{\mathrm{a}}$ geração de hardware clínico norte-americano (Smith \& Nephew / Exogen, Memphis, TE, EUA) EUA)

Fig. 3.3 - $2^{\mathrm{a}}$ geração de hardware clínico norte-americano (Smith \& Nephew / Exogen, Memphis, TE,

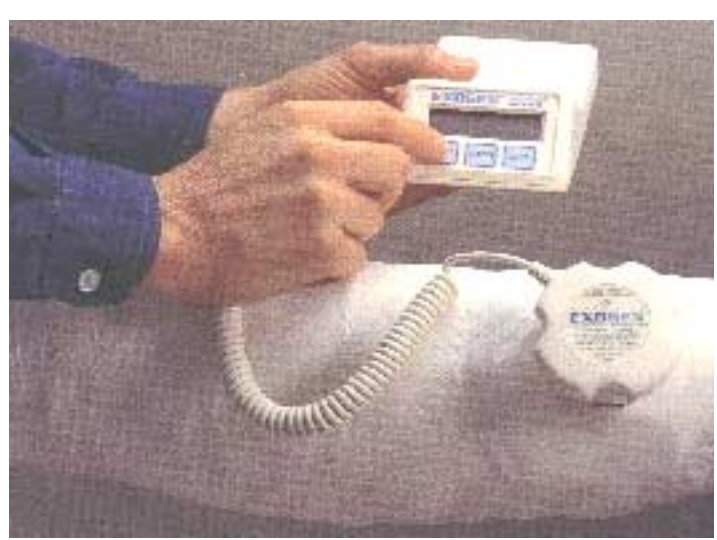

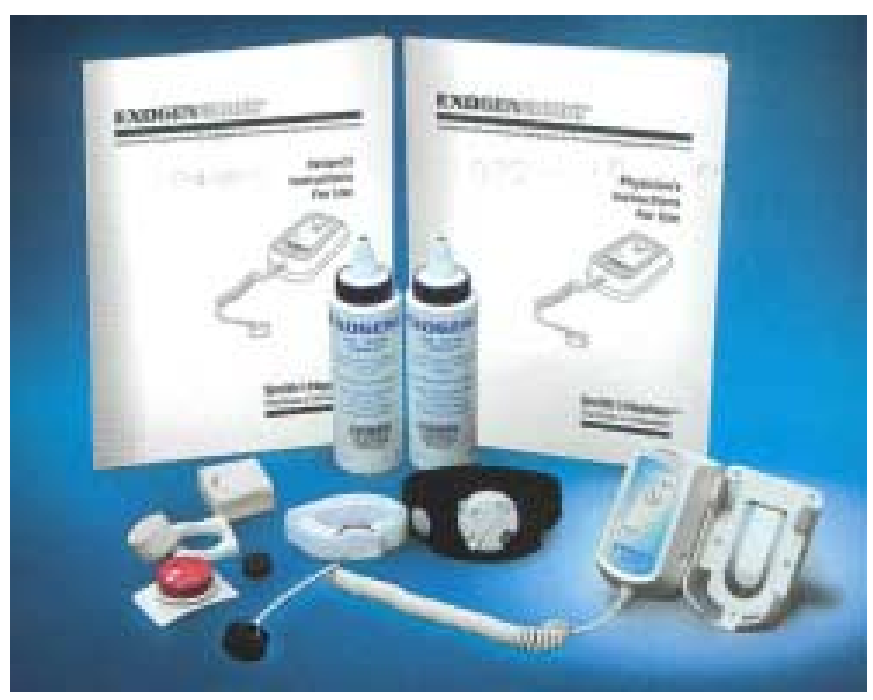

Fig. 3.5 - $4^{\mathrm{a}}$ geração de hardware clínico norte-americano (Smith \& Nephew / Exogen, Memphis, TE, EUA) 
3.2 Efeitos do Ultra-Som de Baixa Intensidade - Novas Aplicações

Os resultados do ultra-som de baixa intensidade no tratamento de fraturas motivaram estudos com animais e clínicos, no Brasil e no exterior, sobre os efeitos desse ultra-som de baixa intensidade na cicatrização de úlceras tróficas da pele (Anastácio, 2000; Hilário, 1993), no tratamento de osteoporose por desuso (Arai et al., 1993), no tratamento de fraturas mandibulares e na osseointegração de implantes metálicos (Tanzer et al. 1996, 2001). Os resultados preliminares são promissores, sugerindo necessidade de maiores investigações clínicas nessas novas áreas de aplicação.

O ultra-som de baixa intensidade foi utilizado em artrodese de coluna, durante 0 processo de fusão póstero-lateral intertransversa (Glazer, 1998) para se avaliar os índices de fusão espinal e as características biomecânicas da massa de fusão em um modelo animal com coelho. Neste estudo foram utilizados 28 animais que foram designados aleatoriamente para serem submetidos a artrodese de coluna.

A fusão intertransversa foi realizada utilizando-se enxerto ósseo autólogo, colhido das cristas ilíacas. Os animais foram divididos em dois grupos com 14 animais, sendo um grupo controle e o outro tratado com ultra-som de baixa intensidade. No grupo controle os animais receberam tratamento placebo, com as unidades de ultra-som desligadas. Os animais do grupo tratado receberam estimulação ultrasônica por 20 minutos diários, durante 6 semanas.

A taxa de pseudoartrose foi de $35 \%$ no grupo controle e de $7 \%$ no grupo tratado. A avaliação foi radiográfica e manual em um modelo duplo cego. $O$ teste biomecânico da massa de fusão mostrou que o ultra-som produziu aumentos estatisticamente significativos na rigidez 
$(33 \%, p=0,03)$, no módulo de tenacidade $(25 \%, p=0,05)$ que é a área sob a curva até a ruptura no gráfico, tensão $X$ deformação, e na carga para a ruptura da massa de fusão $(24 \%, p=0,04)$. A avaliação histológica qualitativa mostrou formação óssea aumentada nas fusões expostas ao ultra-som de baixa intensidade.

Sato et al., (1999), relataram em estudo clínico de alongamento ósseo, um aumento da consolidação através de medidas de densidade óssea devido ao ultra-som de baixa intensidade.

\subsection{Interação do Ultra-Som com Implantes Metálicos}

\subsubsection{Investigações sobre Alterações no Implante}

Diversas publicações abordam o efeito do ultra-som terapêutico convencional sobre os implantes cirúrgicos metálicos (Duarte, 1985). Lehman et al., (1979), relataram, com base em estudos histológicos, que o ultra-som aplicado na presença de implantes metálicos não provocou quaisquer efeitos inconvenientes. Gersten, (1988), afirmou que as elevações de temperatura na região de campo máximo de ultrasom eram menores com metal do que apenas com osso na mesma profundidade. A presença de metal não era uma contra-indicação ao uso do ultra-som. Lotsova, (1979), relatou que pesquisas realizadas com fios de Kirschner utilizados como fixadores, em pacientes tratados com ultra-som, não afetaram a migração dos pinos nem a integridade estrutural dos pinos, segundo determinado por análise metalográfica.

Um estudo do efeito do ultra-som em parafusos internos de fixação realizado em cães concluiu que não foi observado nenhum efeito inconveniente do ultra-som nos parafusos de fixação, e os torques utilizados para afrouxar os parafusos não podiam ser correlacionados ao tratamento por ultra-som (Skoubo-Kristiansen e 
Sommer, 1982). Os estudos acima, em implantes de metal, utilizaram níveis de intensidade de ultra-som variando de $0,5 \mathrm{~W} / \mathrm{cm}^{2}$ até $2 \mathrm{~W} / \mathrm{cm}^{2} e$ não foram observados efeitos inconvenientes. Estas intensidades eram 16 a 60 vezes maiores do que as intensidades utilizadas nos estudos clínicos ou animais com o uso do SAFHS e aqui divulgados. É, portanto, razoável concluir que a presença de metal em uma fratura em processo de cura não afeta a segurança e eficiência do SAFHS para a consolidação das fraturas.

Um Suplemento do PMA (Pre-Market Approval) para o FDA relata estudo, em que analisou-se, se o ultra-som de baixa intensidade, com um nível de intensidade 3 vezes superior à intensidade do sinal clínico normalmente utilizado, durante $\mathbf{3 0}$ horas, afetaria a composição de placas de fixação ortopédicas de aço inoxidável AISI 316-L em um meio fisiológico. Realizou-se uma análise metalográfica após os procedimentos de rotina de eletropolimento, tratamento químico, microscópio óptico e fotografia com ampliações de 55, 110, 220 e 440 vezes. Não foram observadas alterações ou efeitos em placas estimuladas por ultra-som quando comparadas às placas não estimuladas. Com base nestas referências e neste estudo, o ultra-som de baixa intensidade, não prejudica a integridade de materiais de implante ortopédico normalmente utilizados, mesmo após $\mathbf{3 0}$ horas de exposição contínua.

\subsubsection{Investigações sobre Osseointegração em Implantes.}

O sucesso no tratamento de fraturas por ultra-som de baixa intensidade motivaram pesquisas para se avaliar a integração e reparo ósseo na presença de implantes metálicos.

Tanzer et al., (1996) em estudo in-vivo com cães sem raça definida $(n=12)$ avaliou o efeito do ultra-som de baixa intensidade em 
implantes de titânio sinterizados implantados bilateralmente no fêmur. Foram inseridos dois implantes em cada fêmur. Os implantes eram cilíndricos com diâmetro de 4,5mm e comprimento de $9 \mathrm{~mm}$. O tamanho dos poros variou de $100 \mu \mathrm{m}$ à $350 \mu \mathrm{m}$. Em cada animal um fêmur foi utilizado como controle e o outro foi tratado diariamente por ultra-som de baixa intensidade durante 2, 3 ou 4 semanas. Os parâmetros do ultra-som foram os mesmos utilizados no tratamento de fraturas.

O percentual de deposição óssea nos implantes tratados foi de $25,1 \%, 39,6 \%$ e $44,3 \%$ na segunda, terceira e quarta semanas, respectivamente. Nos implantes não tratados 0 percentual de penetração foi de $20.8 \%, 34,1 \%$ e $38,2 \%$ na segunda, terceira e quarta semanas. $O$ aumento na osseointegração foi de $21 \%, 16 \%$ e $16 \%$ nas mesmas semanas. $O$ aumento médio da penetração óssea observado nos implantes tratados, relativo aos três grupos experimentais foi, portanto, de $18 \%$.

Em outra investigação Tanzer et al., (2001), em estudo in-vivo com cães sem raça definida $(n=6)$, investigou o efeito do mesmo ultrasom na osseointegração de implantes porosos de tântalo implantados bilateralmente na ulna. Os implantes eram cilíndricos com diâmetro e $5 \mathrm{~mm}$ e comprimento de $50 \mathrm{~mm}$. 0 tamanho dos poros foi de $430 \mu \mathrm{m}$ e o volume da porosidade variou de $75 \%$ a $80 \%$ do total do implante. Foram inseridos um implante em cada ulna. Em cada animal uma ulna foi utilizada como controle e a outra foi tratada diariamente por ultra-som de baixa intensidade durante 6 semanas. Utilizou-se os mesmos parâmetros do ultra-som para tratamento de fraturas com exceção da intensidade que foi de $250 \mathrm{~mW} / \mathrm{cm}^{2}$.

O percentual de deposição óssea variou de $7.99 \%$ à 18.11 nos implantes tratados por ultra-som e de $2.68 \%$ à $8.5 \%$ nos implantes não 
tratados. O aumento da penetração óssea observado nos implantes tratados variou de $95 \%$ à $198 \%$ com uma média de $119 \%$. 


\section{Biologia óssea na Implantodontia}

\subsection{Estrutura óssea}

Ao colocar implantes na mandíbula e na maxila é importante que os cirurgiões-dentistas entendam o processo da remodelação óssea, os diferentes tipos de osso, e como esses fatores tem implicações na osseointegração dos implantes dentais.

Aproximadamente $0,7 \%$ do esqueleto humano é reabsorvido diariamente e substituído por osso novo e saudável. Com a idade e as doenças metabólicas, o processo de renovação normal pode diminuir, determinando um aumento da idade média do osso. Este aumento pode afetar a futura localização e integração de implantes.

O osso é um tecido vivo que serve a duas funções primordiais: suporte estrutural e metabolismo do cálcio. Ele é composto por uma matriz de proteína colágena que é impregnada com sais minerais, entre os quais se incluem o fosfato de cálcio ( $85 \%)$, o carbonato de cálcio $(10 \%)$, e pequenas quantidades de fluoreto de cálcio e fluoreto de magnésio. ( $5 \%$ somados)

As fibras de proteína colágena que formam a matriz óssea são extremamente complexas. Para se manter a estrutura óssea normal, deve haver um equilíbrio total entre proteínas e minerais. Os minerais encontrados no osso estão presentes primariamente na forma de cristais de hidroxiapatita. 
O conceito de massa óssea é importante, pois o osso é uma estrutura maciça em que a força (resistência) máxima é alcançada com massa mínima devido a sua arquitetura trabecular e a massa óssea desnecessária ou perdida sofre uma remodelação, geralmente sendo reabsorvida.

O osso também contém pequenas quantidades de proteínas não colágenas incluídas em sua matriz mineral. A importante família das proteínas morfogenéticas (PMGs) é parte deste grupo.

\subsection{Osseointegração de Implantes}

\subsubsection{Processo da Osseointegração}

Os estudos sobre implantes de titânio indicam um processo trifásico de osseointegração: fase osteofílica, fase osteocondutiva, e fase de osteoadaptação.

Fase osteofílica

Quando a superfície rugosa do implante é colocada na medula compacta na área da mandíbula ou maxila, apenas um pequeno total de osso trabecular dentro da medula fica em contato com a superfície metálica do implante. A superfície remanescente do implante fica exposta ao espaço fibrogorduroso da medula.

As respostas iniciais apresentadas são: a migração dos osteoblastos e a produção osteóide na superfície do implante. A origem destes osteoblastos é a superfície dos osteoblastos endósteos do osso trabeculado e da superfície das corticais vestibulares e linguais. 
É provável que estas células sejam a resposta à liberação das PMGs no local cirúrgico do implante e a reabsorção inicial do osso compactado contra a superfície metálica. A fase osteofílica dura aproximadamente 1 mês.

\section{Fase osteocondutiva}

Após o contato, as células ósseas difundem-se ao longo da superfície metálica (osteocondução) depositando-se em formação osteóide. 0 osso, que foi previamente formado aparenta geralmente uma camada fina que é denominada "lâmina pedicular" do osso. Esta fase continua nos próximos 3 meses, e mais osso é adicionado à superfície total da área do implante.

Fase de Osteoadaptação

A fase final, a fase de osteoadaptação, inicia-se aproximadamente 4 meses após a colocação do implante, ao mesmo tempo a fase osteocondutiva termina.

Nesta fase, vemos uma situação estável no ganho ou perda de osso compactado ao redor do metal e a relação reabsorção / remodelação que continua mesmo após os implantes serem expostos e submetidos a cargas mecânicas, apresenta-se constante no decorrer dos anos.

\subsubsection{Histórico da osseointegração de Implantes}

As primeiras evidências da utilização de materiais artificiais como implantes dentais para a reabilitação oral são de achados e 
escritas do antigo Egito. Provavelmente a mais recente peça obtida, mostrando a utilização desses materiais artificiais, data de 600 A.C..

Em restos de um crânio encontrado em escavações Maias foram encontrados pedaços de conchas esculpidos a mão para se parecerem com incisivos inferiores (fig. 4.1).

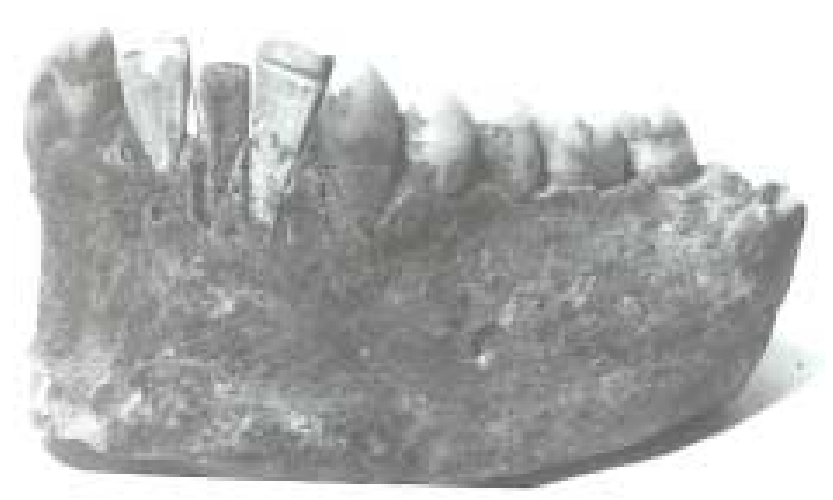

Fig. 4.1 - Peça exposta no museu de arqueologia e etnologia da Universidade de Harvard, Cambridge, Massachusetts

(Dentistry: an illustrated history, 1985 - Mosby)

Apesar destes relatos muito antigos, a utilização de materiais sintéticos para serem implantados com a finalidade de substituição das estruturas dentais somente foi ser realmente iniciada no início do século XIX, onde relatos de implantações com ouro, iridium e prata, tiveram a sua importância.

Todos estes materiais foram implantados nos arcos dentais com a função de suportar coroas dentais após a cicatrização dos tecidos moles. Outros materiais foram também testados no decorrer dos séculos XIX e XX como a porcelana, platina, ligas áureas entre outros.

Somente no início da década de 30 é que a "implantodontia", como hoje é denominada, teve o seu amadurecimento com o advento dos implantes justa-ósseos, ou subperiostais, de cromo-cobaltomolibdênio, mais conhecido no meio odontológico com Vitalium. 
Essa técnica de implantes subperiostais com Vitalium perdurou por várias décadas, mesmo com o advento e maior número de pesquisas sobre os implantes endósseos, que acabaram por substituilos totalmente.

Relatos isolados (Strock, 1939), iniciaram a fase da busca por um método que substituísse os dentes de forma unitária, assim, através da inserção de um suporte metálico dentro do alvéolo de um dente removido precocemente.

Tantos eram os pesquisadores envolvidos na busca de um material e uma maneira de proporcionar suporte para as estruturas dentais, que inúmeros desenhos de implantes, com materiais bem variados, foram disponibilizados para este fim.

$\mathrm{Na}$ décadas de 50 e 60, implantes com formatos espirais, laminados, em dupla hélice, cilíndricos, trans-mandibulares, enfim, os mais variados, foram desenvolvidos para serem utilizados na reabilitação oral.

Também na década de 50 iniciaram-se as pesquisas de um pesquisador suéco chamado Bränemark. $O$ seu trabalho, de tanta valia, praticamente dita as normas da implantodontia até os dias de hoje.

Linkow, (1963), após ter tido anos de sucesso com implantes em formato de lâmina desenvolveu o seu primeiro implante cilíndrico, modelo que apesar das modificações técnicas é conceitualmente seguido até os dias de hoje.

Baseado nesses modelos e em experiências realizadas na década de 60 particularmente sobre o modelo cilíndrico, Bränemark e 
Albrektsson, no início dos anos 80 , praticamente determinaram os conceitos para a reabilitação oral de pacientes com o uso de implantes e o conceito de osseointegração (Bränemark PI, 1985).

Suas publicações estão fundamentadas em mais de 20 anos de experiências e resultados com implantes cilíndricos, feitos de titânio, material com uma excelente biocompatibilidade nos tecidos humanos e com biomecânica adequada para suportar as cargas mastigatórias e 0 meio ácido ao qual estaria sendo exposto.

A utilização dos implantes de titânio para a reabilitação oral passou a ser a primeira escolha para vários cirurgiões-dentistas na reabilitação de seus pacientes.

Inúmeros outros pesquisadores lançaram no mercado sistemas de implantes parecidos tecnicamente mas iguais conceitualmente ao modelo proposto por Bränemark, tais como os sistemas IMZ, proposto por Kirsch (1983), Core-Vent, proposto por Niznick (1982), Steri-Oss, proposto por Denar e Hahn (1988). Eles são utilizados até os dias de hoje com algumas modificações e melhorias.

A maioria destes implantes seguem praticamente a "metodologia de duas fases": a primeira, sua colocação, da forma mais atraumática possível em relação ao leito receptor do implante; a segunda, após um tempo de espera para a osseointegração de no mínimo 16 semanas, para a sua abertura cirúrgica para a boca e posterior construção de uma prótese, adaptada à porção mais superior e emergente destes implantes. Na figura 4.2 estão exemplificados alguns tipos de reabilitação com implantes.

Após os relatos iniciais de Bränemark (1965 e 1969), seguindo a filosofia da osseointegração, pesquisadores suíços lançaram um sistema de implantes não submergível, ou seja, em uma única fase. 
Este sistema recebeu o nome de ITI, e também é utilizado até a presente data.

Esses sistemas utilizam-se do conceito inicialmente gerado pelas pesquisas de Bränemark, que com seu conceito de osseointegração (que basicamente é a melhor união mecânica do implante ao osso, sem tecido de granulação interposto entre estas estruturas) acabou por traçar e definir o desenho e maneira de se reabilitar um paciente de várias formas.
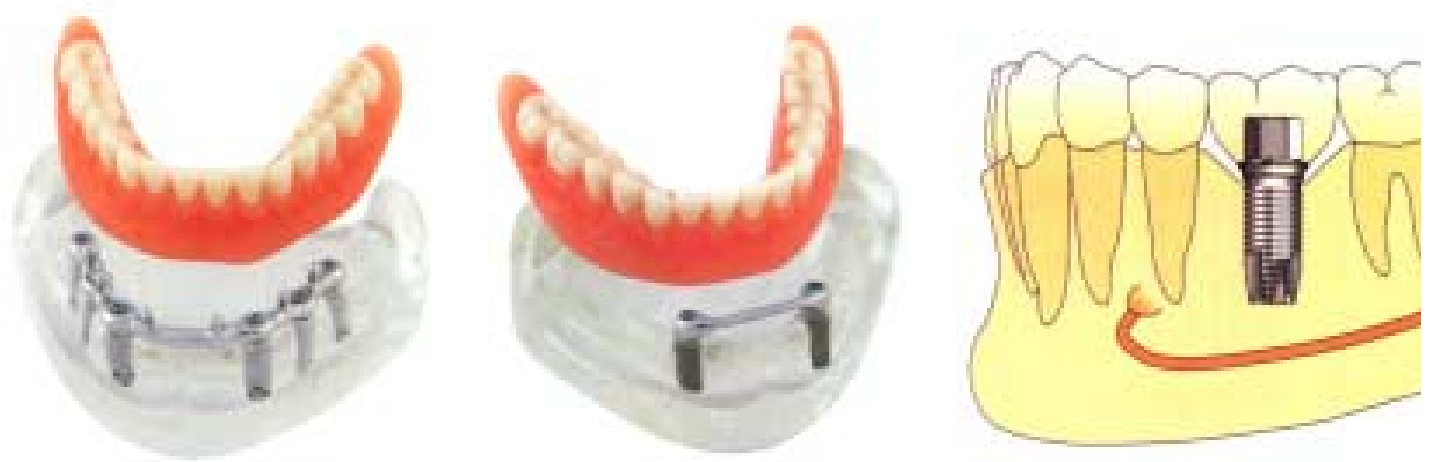

Fig. 4.2 - Algumas das aplicações clínicas para reabilitação de pacientes com implantes de titânio aplicados à Odontologia (catálogo - Branemark)

O termo osseointegração passou por vários ajustes de definição dadas por vários autores, e mais recentemente aceita-se como sendo osseointegração as modificações pelas quais o osso passa, sendo induzido a incorporar permanentemente um elemento sintético, no caso, os implantes. (Bränemark PI et al.., 1977). As definições de osseointegração, voltadas para a implantodontia, podem ser descritas como sendo:

- Um perfeito contato entre implante e osso, sem a presença de tecido conectivo interposto (Misch, 1992). 
- Um contato direto, estrutural e funcional, do tecido ósseo e do implante, submetido a carga mastigatória (Bränemark PI et al., 1985).

- A coexistência estrutural e funcional entre os tecidos biológicos e materiais sintéticos, promovendo resultados clínicos duradouros, sem iniciar-se uma resposta de rejeição ou lise óssea ao redor do implante, por parte do organismo. (Bränemark R, 1998).

Portanto, diz-se que um implante está biomecanicamente osseointegrado quando não ocorre nenhuma resposta de reabsorção óssea ao redor dos implantes submetidos a carga mastigatória, durante a vida útil do implante (Bränemark $R, 1998$ ). A figura 4.3 apresenta a seqüência da biologia envolvida na osseointegração.

Para conseguir esta osseointegração foi desenvolvido um protocolo cirúrgico para a colocação de implantes para a reabilitação oral:

a) Uso de um material altamente biocompatível; como o implante de titânio, com características específicas de superfície que permitiram o melhor contato implante / osso.

b) Desenho de sua estrutura endóssea que favorece a distribuição das forças a ela aplicadas associado a uma excelente técnica atraumática para sua inserção.

c) Tempo necessário para que exista uma boa cicatrização e remodelamento ósseo.

Com estes procedimentos é possível obter-se a situação citada anteriormente, onde estes implantes coexistem em função, sem 
promover nenhum tipo de reabsorção óssea ou alteração tecidual deletéria (Bränemark et al., 1992).

Apesar de existir uma adaptação óssea fisiológica após a sua inserção até a fase de ativação (adaptação essa que resulta em reabsorção óssea na região mais superior), no decorrer dos anos esta reabsorção tende a se minimizar, tendo uma evolução mínima e clinicamente desprezível na vida clínica deste implante (Bränemark et al., 1969) como exemplificado na figura 4.4.

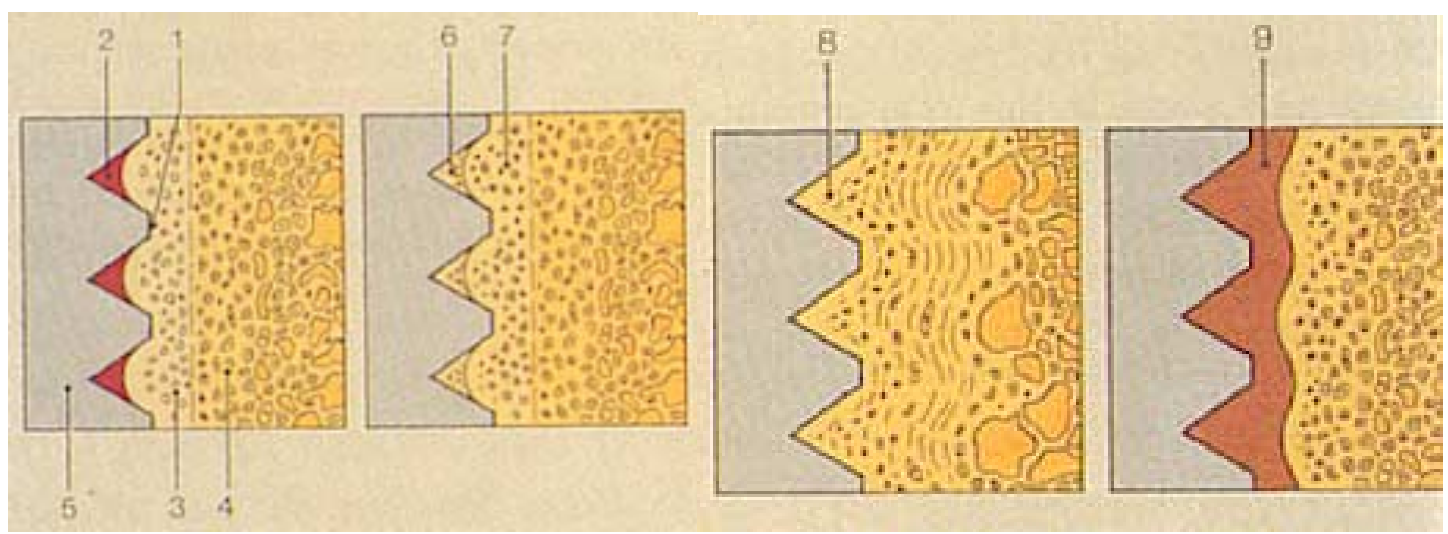

1. Contato entre implante e osso - promove a imobilização inicial.

2. Hematoma presente, dentro de uma cavidade fechada, tendo o osso e o implante como suas paredes.

3. Osso afetado por traumas, mecânicos e térmicos.

4. Osso saudável.

5. Implante de titânio.

6. Osso em fase de reparação durante período de ausência de estímulos ou cargas no implante.

7. Osso traumatizado previamente, também em fase de reparação, com neoformação vascular e óssea (desmineralização / remineralização

8. Osso em íntimo contato com o implante após o período de sepultamento, sem nenhum tecido interposto.

9. Insucesso na fase de integração, existe tecido conjuntivo interposto entre implante de titânio e osso (não osseointegrado).

Fig. 4.3 - Seqüência da Biologia da Osseointegração

(Fonseca, 1996) 
36

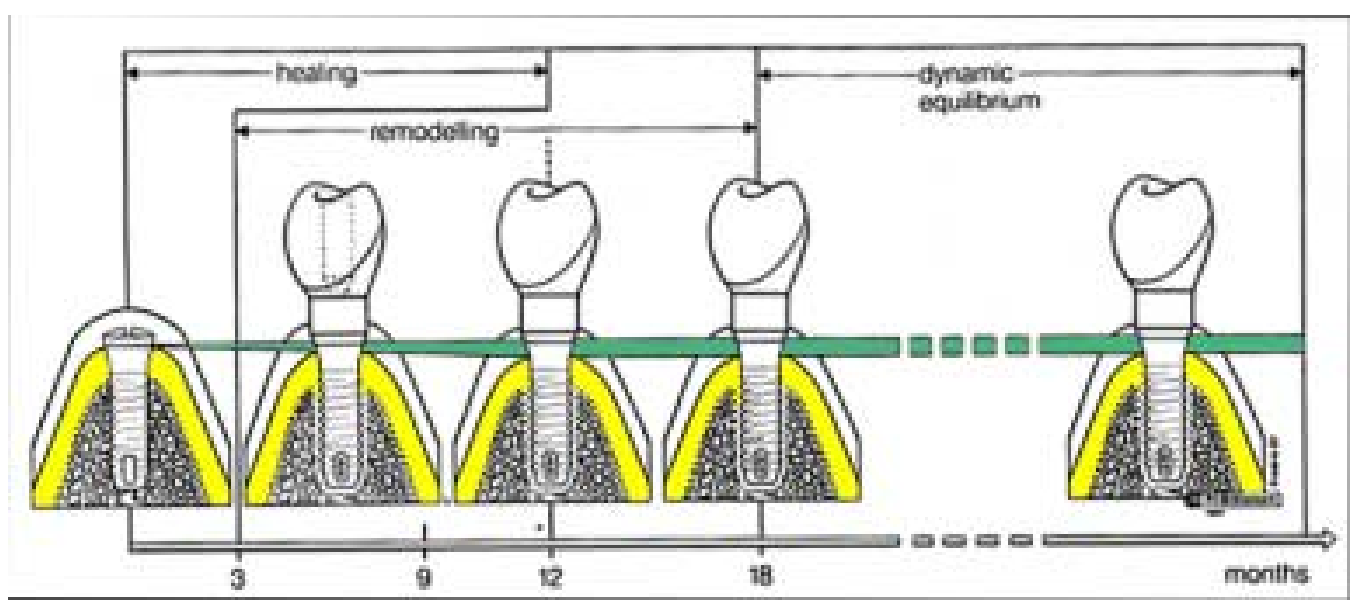

Fig. 4.4 - Seqüência de eventos no decorrer do tempo em relação à manutenção da osseointegração e reabsorção óssea (Fonseca, 1996) 


\section{Material e Método}

\subsection{Animais e Implantes}

Coelhos da raça Nova Zelândia $(n=18)$, machos com peso entre 2,5 e $3,0 \mathrm{Kg}$, foram submetidos à cirurgia para implantação na tíbia direita e esquerda de dois implantes dentais comerciais de titânio para uso em reabilitação oral, num total de 72 implantes colocados.

Foram utilizados implantes similares aos do tipo Bränemark (Nobelpharma USA, Chicago, IL) fornecidos pela empresa "Conexão Sistemas de Prótese Ltda." com comprimento de $8,5 \mathrm{~mm}$, diâmetro de $3,75 \mathrm{~mm}$ e superfície de titânio tratada através de subtração ácida (STE) para o aumento da "rugosidade" da superfície. A figura 5.1 mostra o implante utilizado neste estudo. Nas figuras 5.2 à 5.4 observa-se o seu uso em humanos. Na figura 5.5 observa-se a comparação dimensional entre a tíbia do coelho e o implante utilizado.

Uma vista anatômica do fêmur e tíbia de um coelho é mostrada nas figuras 5.6 e 5.7. A posição dos implantes na tíbia é vista nas imagens radiográficas mostradas na figura 5.25.

A distância entre os implantes foi de $5 \mathbf{m m}$ (figura 5.8). Eles foram colocados à aproximadamente $7 \mathrm{~mm}$ da porção articular proximal da tíbia. 


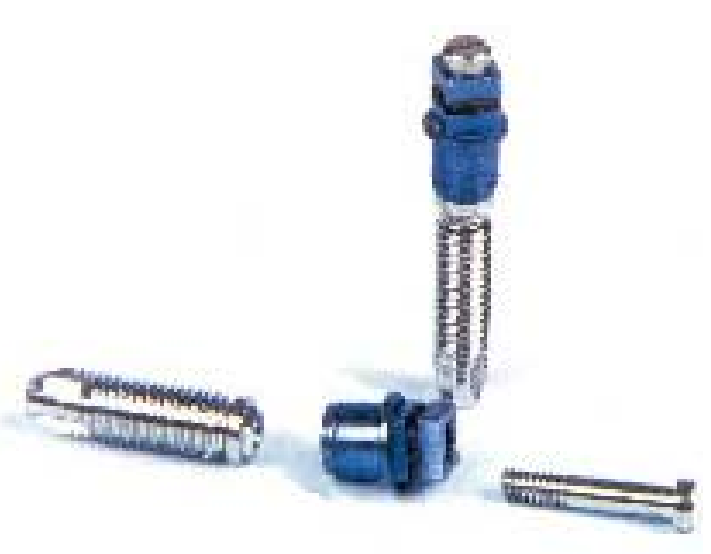

Fig. 5.1 - Implante dental comercial de titânio master screw ${ }^{\circledR}$ (Catálogo - Conexão)

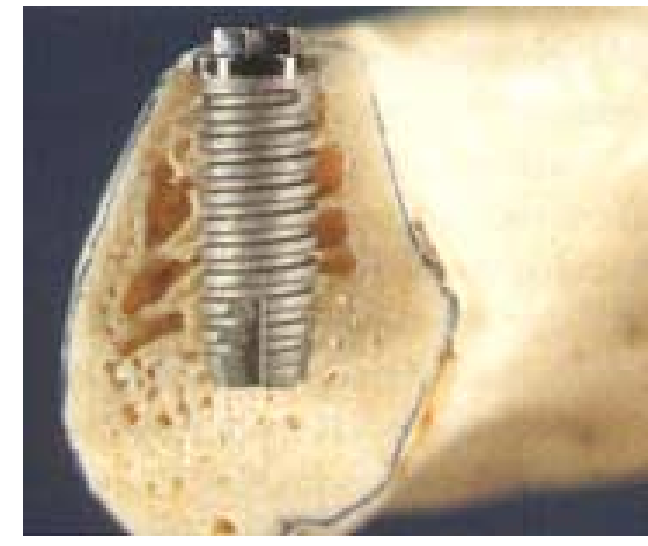

Fig. 5.2 - Corte transversal da mandíbula com um implante de titânio colocado (Catálogo - Biohorizons)
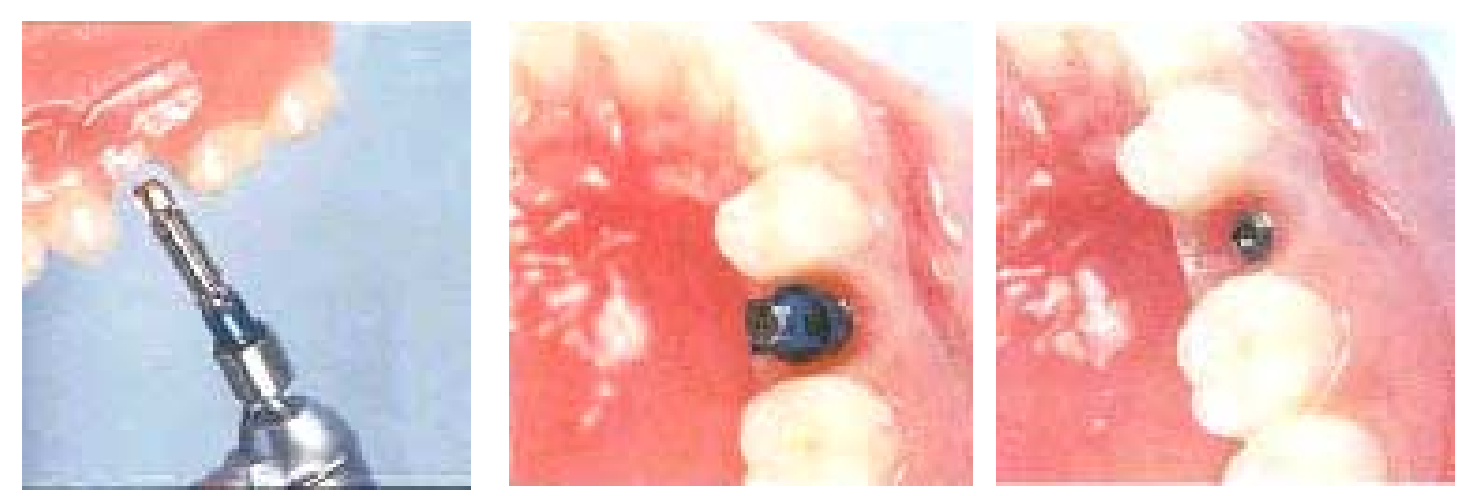

Fig. 5.3 - Exemplo de uso clínico do Implante master screw ${ }^{\circledR}$

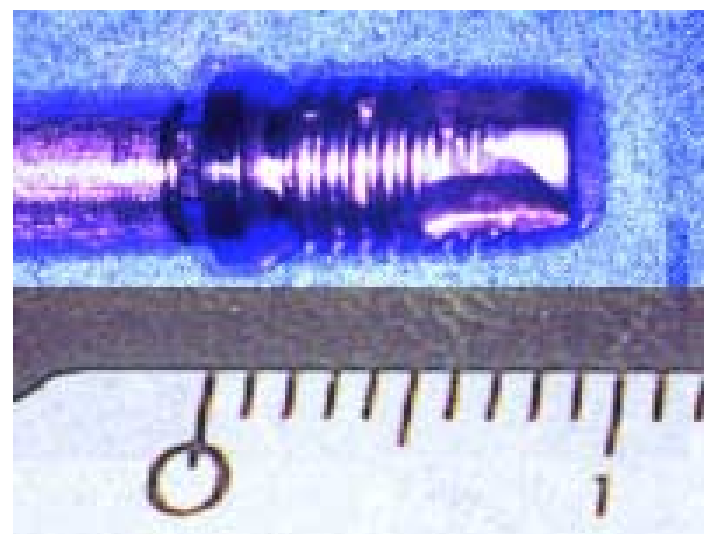

Fig. 5.4 - Vista comparativa do implante de titânio em relação à tíbia do coelho 


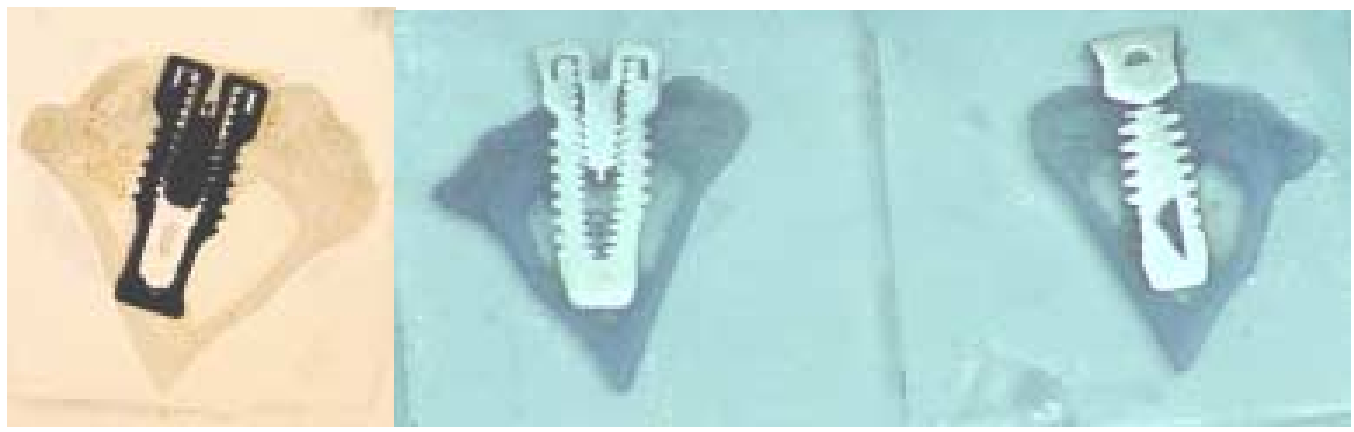

A

B

C

Fig. 5.5 - Corte transversal da tíbia de coelho com um implante de titânio colocado ( $A$ - sem coloração e B,C - com azul de toluídina)

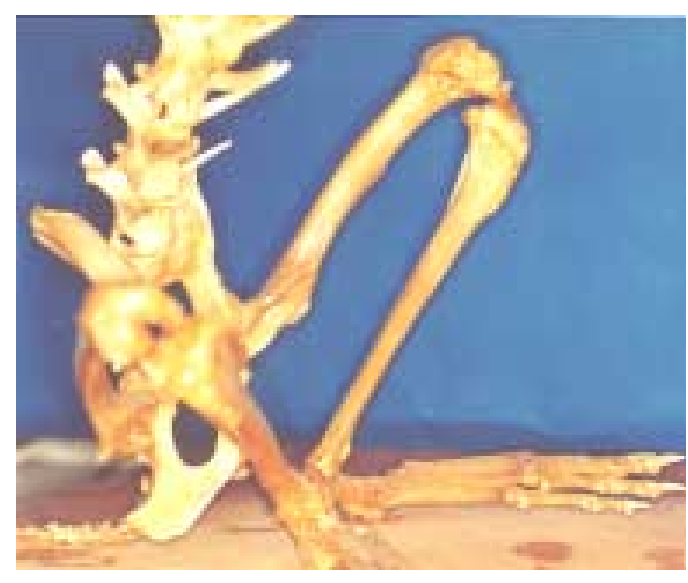

Fig. 5.6 - Vista do fêmur e da tíbia do coelho

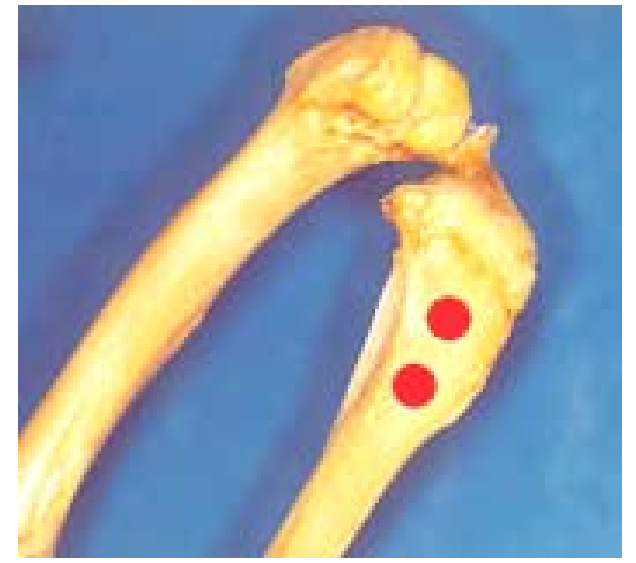

Fig. 5.7 - Vista da face medial da tíbia e do local que recebeu os implantes

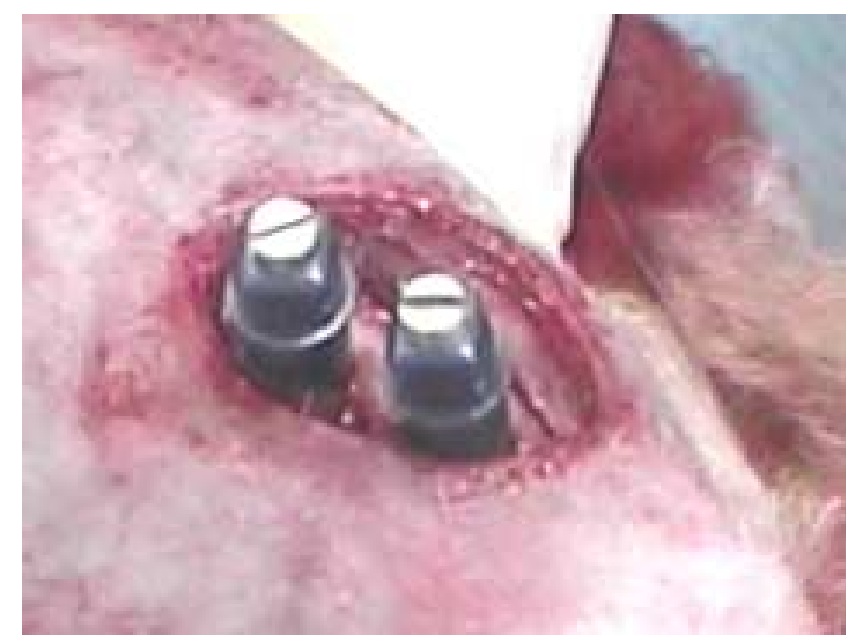

Fig. 5.8 - Distância entre os implantes 


\subsection{Grupos Experimentais}

Foram estabelecidos três grupos experimentais. Nos animais de todos os grupos foram colocados 2 implantes de titânio na tíbia esquerda e direita. Nos grupos 1, 2 e 3 os pares de implantes colocados na tíbia direita foram tratados por ultra-som. Os pares de implantes colocados na tíbia esqueda foram utilizados como controle.

O número de animais em cada grupo experimental, a utilização ou não do tratamento por ultra-som, o tempo do tratamento e a data de sacrifício dos animais são mostrados na tabela 5.1.

Tabela 5.1 - Grupos Experimentais

\begin{tabular}{cccccc}
\hline $\begin{array}{c}\text { Grupo } \\
\text { Experimental }\end{array}$ & $\begin{array}{c}\text { Número de } \\
\text { Animais }\end{array}$ & \multicolumn{2}{c}{$\begin{array}{c}\text { Tratamento por } \\
\text { Ultra-Som } \\
\text { Tíbia E }\end{array}$} & $\begin{array}{c}\text { Tŕbia D } \\
\text { por Ultra-Som } \\
\text { (dias) }\end{array}$ & $\begin{array}{c}\text { Data do } \\
\text { Sacrifício } \\
\text { (dia) }\end{array}$ \\
\hline 1 & 6 & Sim & Não & 21 & \\
2 & 6 & Sim & Não & 35 & $2^{\circ}$ \\
3 & 6 & Sim & Nao & 49 & $56^{\circ}$ \\
\hline
\end{tabular}

A osseointegração nos implantes foi avaliada através de ensaios mecânicos de arrancamento e de torque para retirada dos implantes e análise do tecido osseointegrado por histomorfometria. A tabela $\mathbf{5 . 2}$ mostra o número de implantes utilizados em cada método de avaliação.

\begin{tabular}{|c|c|c|c|c|c|c|}
\hline \multicolumn{7}{|c|}{ Tabela 5.2 - Número de Implantes por Método de Avaliação } \\
\hline \multirow{3}{*}{$\begin{array}{c}\text { Grupo } \\
\text { Experimental }\end{array}$} & \multicolumn{6}{|c|}{ Número de Implantes } \\
\hline & \multicolumn{2}{|c|}{$\begin{array}{l}\text { Ensaio de } \\
\text { Arrancamento } \\
\text { Tratamento por } \\
\text { Ultra-Som }\end{array}$} & \multicolumn{2}{|c|}{$\begin{array}{l}\text { Ensaio de } \\
\text { Torque } \\
\text { Tratamento por } \\
\text { Ultra-Som }\end{array}$} & \multicolumn{2}{|c|}{$\begin{array}{c}\text { Análise } \\
\text { Histomorfométrica } \\
\text { Tratamento por } \\
\text { Ultra-Som }\end{array}$} \\
\hline & Sim & Não & Sim & Não & Sim & Não \\
\hline 1 & 4 & 4 & 4 & 4 & 4 & 4 \\
\hline 2 & 4 & 4 & 4 & 4 & 4 & 4 \\
\hline 3 & 4 & 4 & 4 & 4 & 4 & 4 \\
\hline TOTAL & 12 & 12 & 12 & 12 & 12 & 12 \\
\hline Soma Total & & & 72 & Jlantes & & \\
\hline
\end{tabular}




\subsection{Cirurgia}

As cirurgias foram realizadas sob normas específicas de assepsia, anti-sepsia e técnica adequada para a sua realização. Os animais receberam anestesia geral através da administração de Francotar (Ketamina - 0,25 ml/Kg) e Virbaxyl (Cloridato de Xylazina $0,20 \mathrm{ml} / \mathrm{Kg}$ ), com um jejum de 6 horas antes do procedimento.

Após tricotomia e assepsia do sítio cirúrgico com PVPI (Povidine) foi realizada anestesia local, utilizando-se aproximadamente 0,9 ml de mepivacaína 3\% com Levonordefrina (Mepivacaína ${ }^{\circledR}$ - DFL.) em cada tíbia para facilitar o procedimento devido à vasoconstrição local. No acesso cirúrgico, realizou-se divulsão de tecidos e preparo do leito para receber os implantes, seguindo as normas já conhecidas e de acordo com as determinações da empresa "Conexão Sistemas de Prótese Ltda.". Foram colocados 2 implantes na face medial das tíbias esquerda e direita de cada animal. A distância entre os implantes foi de $5 \mathrm{~mm}$ e à aproximadamente $7 \mathrm{~mm}$ da porção articular proximal das tíbias.

Na figura 5.9 observa-se a seqüência de brocas utilizadas para realizar-se a perfuração óssea e a posterior colocação dos implantes.

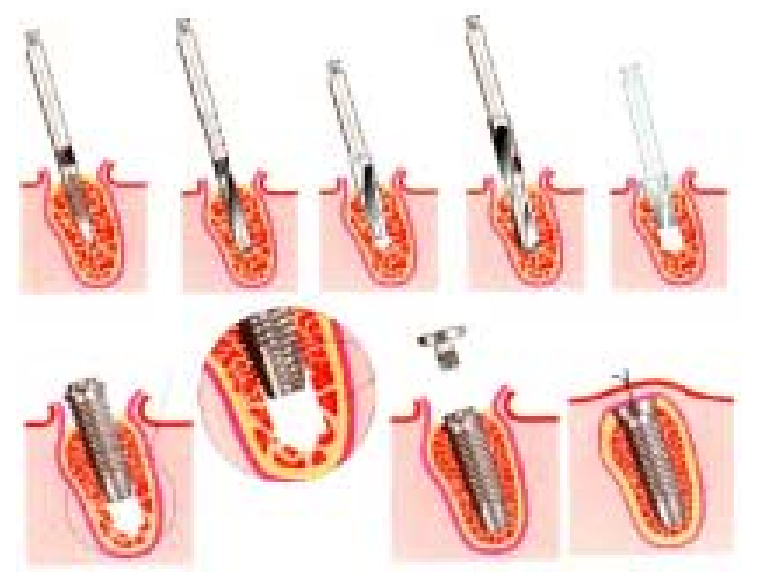


Fig. 5.9 - Seqüência padrão de perfuração óssea na realização de implantes de titânio (Catálogo - Conexão Sistemas de Prótese - Brasil)

A seqüência cirúrgica é mostrada nas figuras 5.10 à 5.24 . Primeiramente é realizada uma perfuração com broca de $1.6 \mathrm{~mm}$ de diâmetro, seguida de perfuração com a broca de $2.0 \mathrm{~mm}$ de diâmetro. Uma broca piloto de 2.0 para $3.0 \mathrm{~mm}$ é passada a seguir. Utiliza-se então a broca de $3.0 \mathrm{~mm}$ e uma broca para fazer um desgaste maior na cortical (counter-sink). Finalmente, se necessário, é feita uma rosca, com um dispositivo próprio do kit de brocas para implantes. A colocação do implante é então realizada de forma tradicional, removendo-se o montador de implantes por último e colocando-se os protetores de rosca (cover-screws) antes de se fazer a sutura final.

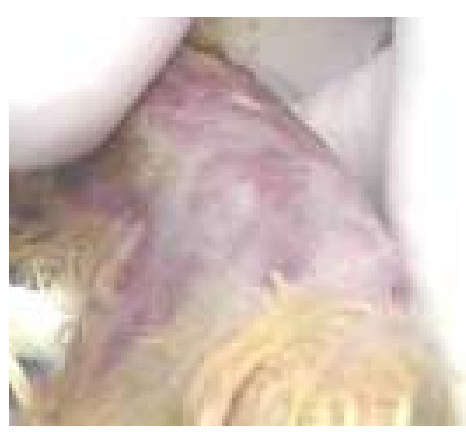

Fig. 5.10 - Área a ser operada na face medial da tíbia do coelho

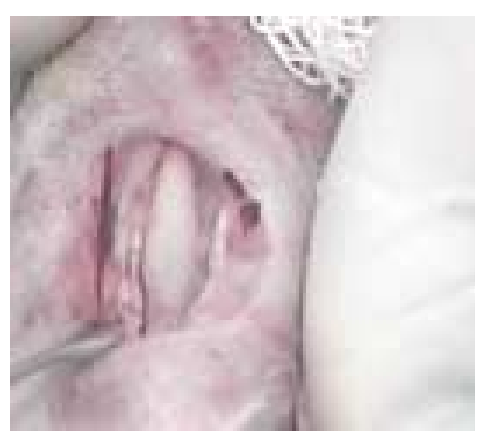

Fig. 5.13 Descolamento do periósteo

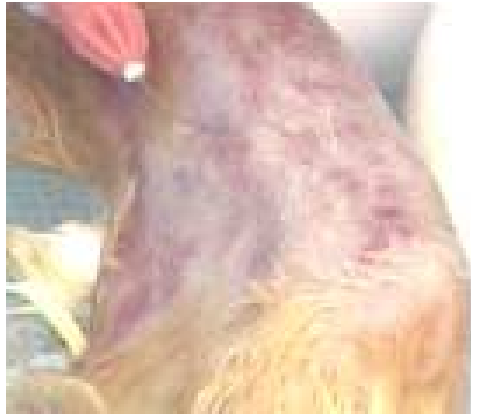

Fig. 5.11 - Anestesia infiltrativa para melhorar a hemostasia intraoperatória

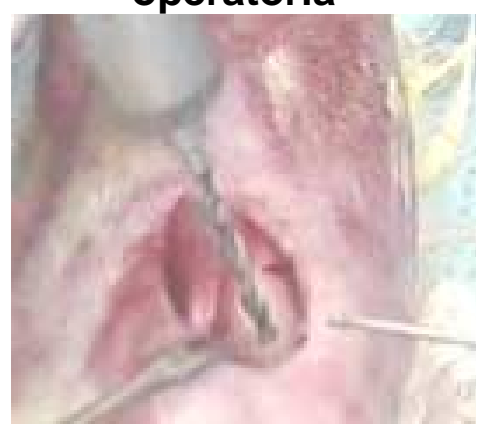

Fig. 5.14 - Perfuração com broca de $1.6 \mathrm{~mm}$ de diâmetro

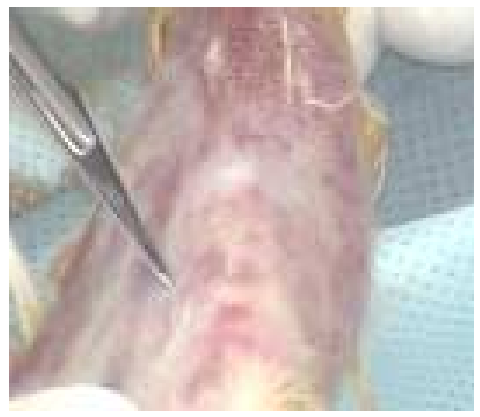

Fig. 5.12 - Incisão feita com lâmina 11, diretamente ao osso

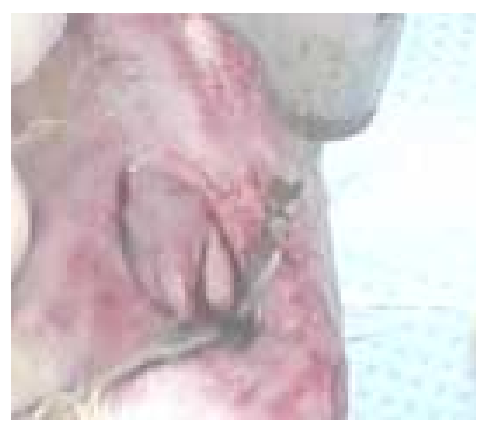

Fig. 5.15 - Perfuração com broca de $2.0 \mathrm{~mm}$ de diâmetro 


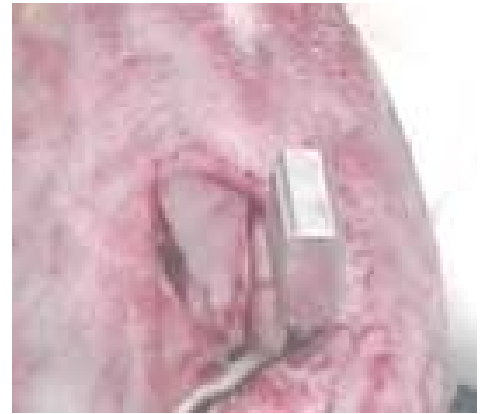

Fig. 5.16 - Colocação de guia para correta distância e paralelismo

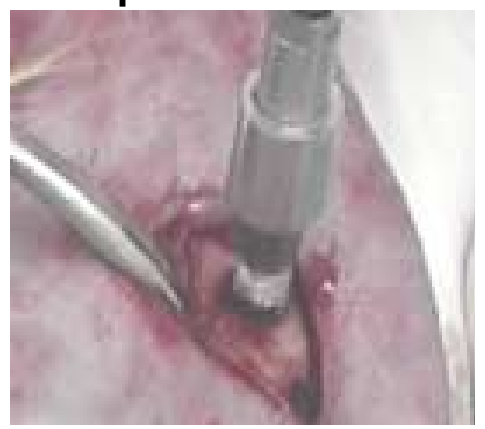

Fig. 5.19 - Implante de 3,75 X 8,5 colocado na face medial da tíbia

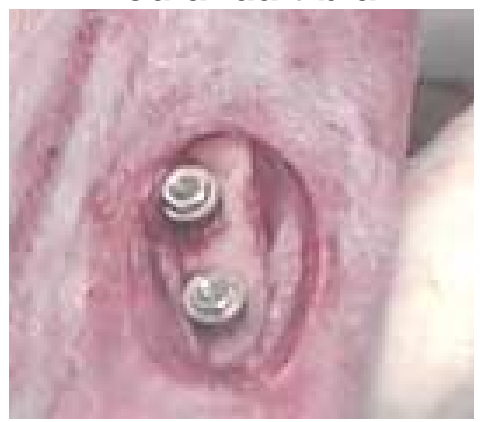

Fig. 5.22 - Implantes sem os montadores

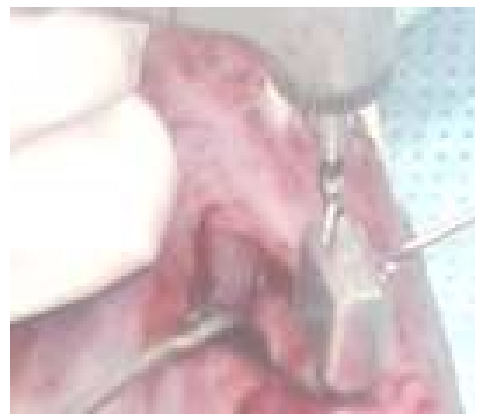

Fig. 5.17 - Perfuração para segundo implante (broca de 1.6 $\mathrm{mm}$ )

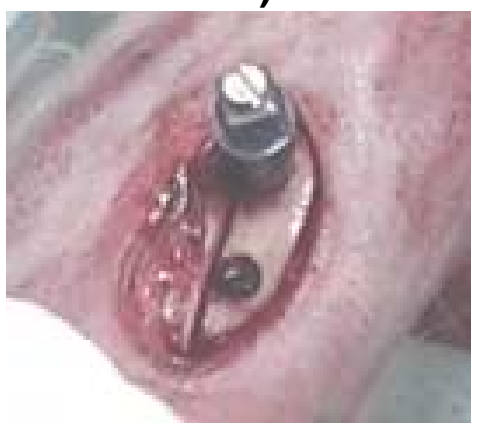

Fig. 5.20 - Implante proximal colocado.

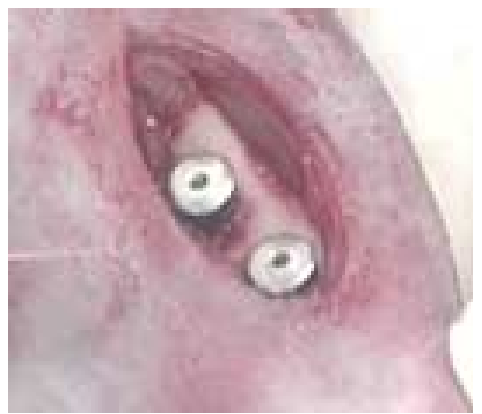

Fig. 5.23 - Implantes com os cover-screws

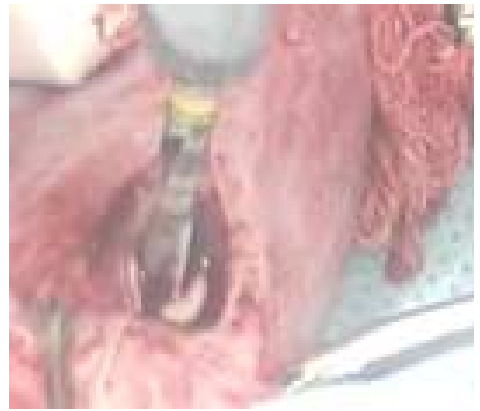

Fig. 5.18 - Perfuração final (broca de 3.0 $\mathrm{mm}$ )

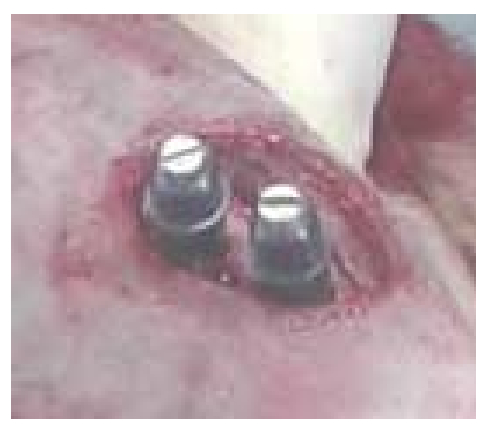

Fig. 5.21 - Implantes colocados, ainda com os montadores

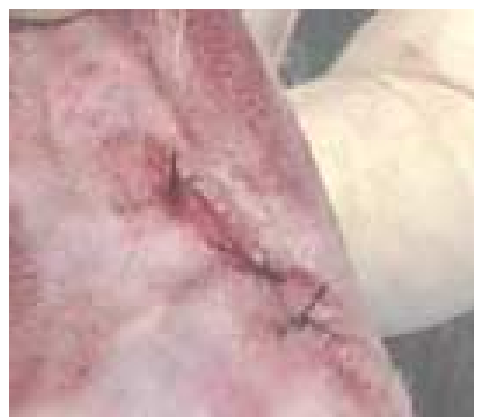

Fig. 5.24 - Sutura da área operada 


\subsection{Exame Radiográfico}

Radiografias para observação dos posicionamento dos implantes formam realizadas após a cirurgia de cada animal. A posição dos implantes na tíbia é vista nas imagem radiográfica mostrada nas figura 5.25

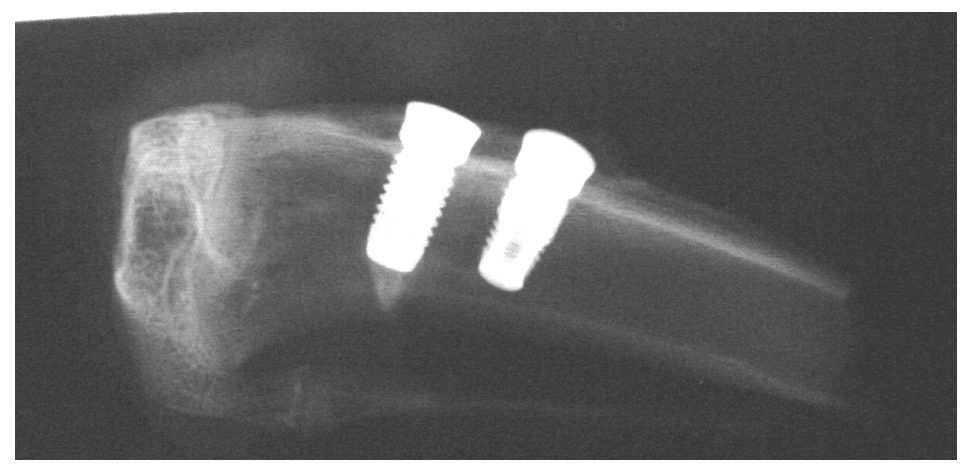

Fig. 5.25 - Radiografia lateral dos implantes de 3,75 X 8,5 mm

\subsection{Tratamento por Ultra-Som}

O ultra-som foi transmitido de medial para lateral em relação à perna, de modo a incidir lateralmente nos implantes. Os implantes nas tíbias do lado esquerdo foram tratados por ultra-som durante 20 minutos por dia durante todo o experimento, de acordo com o período de vida de cada grupo (3, 5 e 7 semanas). Os implantes nas tíbias do lado direito não foram tratados por ultra-som e serviram como controle.

O ultra-som tem as mesmas características dos aparelhos usados clinicamente para o tratamento de fraturas. O transdutor é um disco cerâmico de PZT (Titanato de Zirconato de Chumbo) que emite ondas longitudinais. O sinal elétrico que excita o transdutor tem freqüência de $1,5 \mathrm{MHz}$, largura do pulso de $200 \mu$ s e freqüência de pulso de $1 \mathrm{KHz}$ (figura 5.26). 


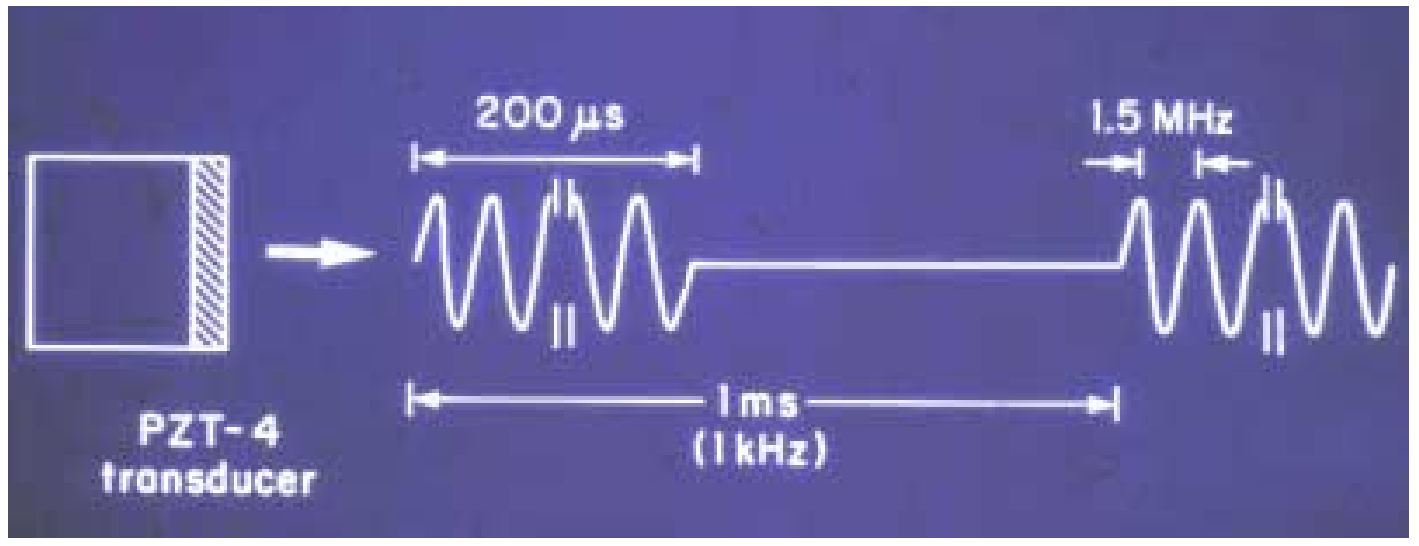

Fig. 5.26 - Sinal elétrico que excita o transdutor ultra-sônico

A intensidade do ultra-som foi medida no laboratório do Grupo de Bioengenharia do Departamento de Engenharia de Materiais, Aeronáutica e Automobilística da EESC-USP utilizando-se uma balança de radiação acústica (modelo UPM DT-1, Ohmics Instruments, EUA). 0 valor médio da intensidade medida ao longo do experimentos foi de $35.01 \pm 2.92 \mathrm{~mW} / \mathrm{cm}^{2}$. Um gel de acoplamento foi utilizado na superfície do transdutor que esteve em contato com a pele do animal previamente tricotomizada. As figuras 5.27 à 5.29 ilustram o método de aplicação do ultra-som nos implantes colocados na tíbia esquerda dos animais.

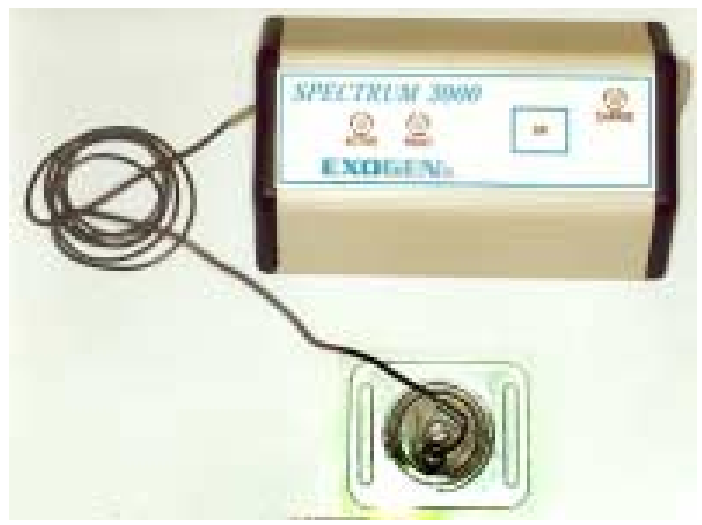

Fig. 5.27 - Aparelho de ultra-som de baixa intensidade

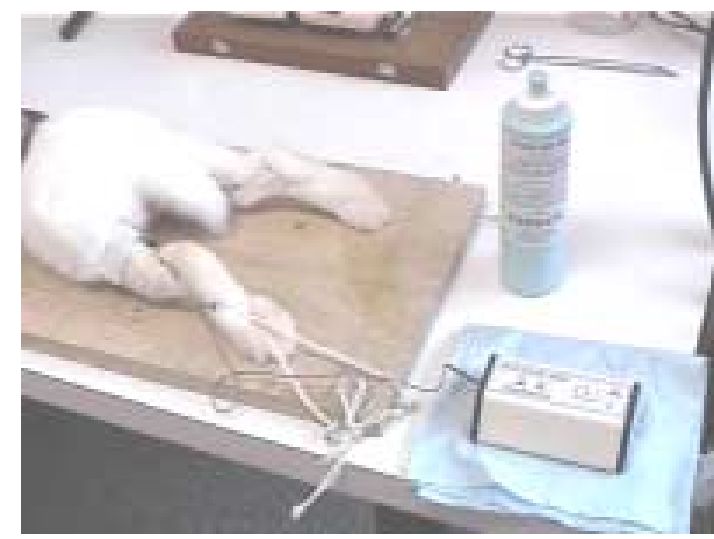

Fig. 5.28- Animal imobilizado com o transdutor colocado na face medial da tíbia esquerda 


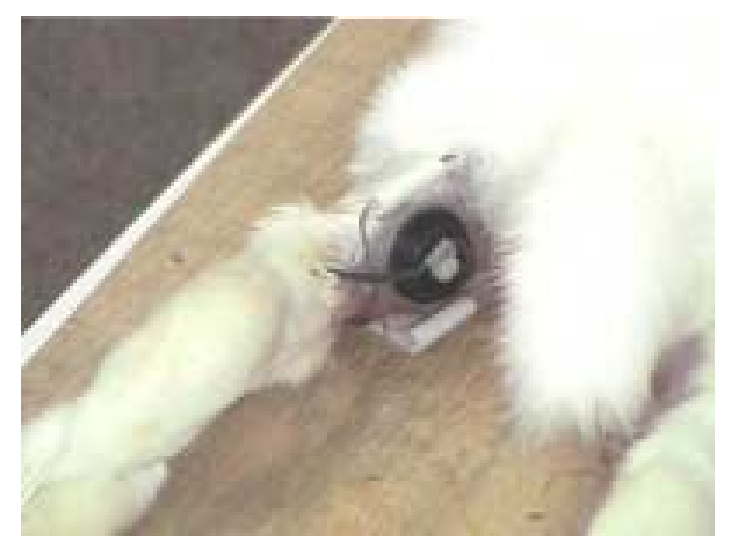

Fig. 5.29 - Aplicação do ultra-som na face medial da tíbia esquerda

\subsection{Análise Histomorfométrica}

Todos os animais cujos implantes foram submetidos a análise histomorfométrica receberam injeções de um marcador ósseo (tetraciclina) para se avaliar o processo metabólico ósseo. 0 marcador foi administrado conforme descrito na Tabela 5.3

\begin{tabular}{cccc}
\hline \multicolumn{4}{c}{ Tabela 5.3 - Administração de tetraciclina } \\
\hline $\begin{array}{c}\text { Grupo } \\
\text { Experimental }\end{array}$ & $\begin{array}{c}\text { Número de } \\
\text { animais }\end{array}$ & $\begin{array}{c}\text { Injeção de } \\
\text { tetraciclina IM (dia) }\end{array}$ & $\begin{array}{c}\text { Sacrifício } \\
\text { (dia) }\end{array}$ \\
\hline 1,2 e 3 & 6 & $1^{\circ}$ e 2 & \\
1,2 e 3 3 & 6 & $15^{\circ}$ e $16^{\circ}$ & $22^{\circ}$ \\
2 e 3 & 4 & $29^{\circ}$ e $30^{\circ}$ & $36^{\circ}$ \\
3 & 2 & $43^{\circ}$ e $44^{\circ}$ & $50^{\circ}$ \\
\hline
\end{tabular}

As tíbias com os implantes foram submetidas a procedimentos para a obtenção das lâminas para análise histomorfométrica, conforme as etapas de 1 à 6 :

Etapa 1: Manutenção em solução de formol a 10\% durante 48 horas.

Etapa 2 - Lavagem em água corrente durante $24 \mathrm{~h}$ e desidratação nas seguintes soluções: 


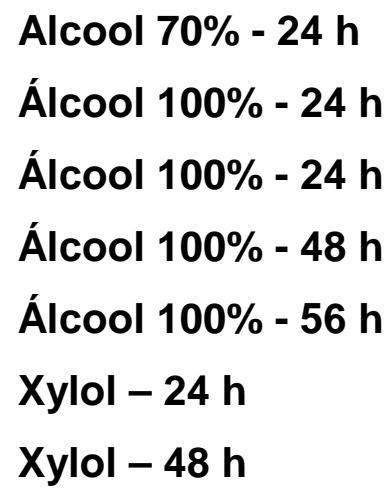

Etapa 3: Inclusão nas seguintes soluções:

Semana 1: Solução de Dibutilftalato (15 ml) + Metilmetacrilato (75 ml) Peróxido de benzoila (1 gr / 100ml) Estufa a $60{ }^{\circ} \mathrm{C}-24 \mathrm{~h}$.

Semana 2: Solução de Dibutilftalato (15 ml) + Metilmetacrilato $(75 \mathrm{ml})$ + Peróxido de benzoila (1 gr / 100ml) Estufa a $60^{\circ} \mathrm{C}-24 \mathrm{~h}$

Semana 3: Solução de Dibutilftalato $(15 \mathrm{ml})+$ Metilmetacrilato $(75 \mathrm{ml})$ + Peróxido de benzoila ( $5 \mathrm{gr} / 100 \mathrm{ml})$ Estufa a $60^{\circ} \mathrm{C}-24 \mathrm{~h}$

A figura 5.30 mostra a tíbia com os implantes incluída em bloco de metilmetacrilato, após a execução das etapas de 1 à 3.
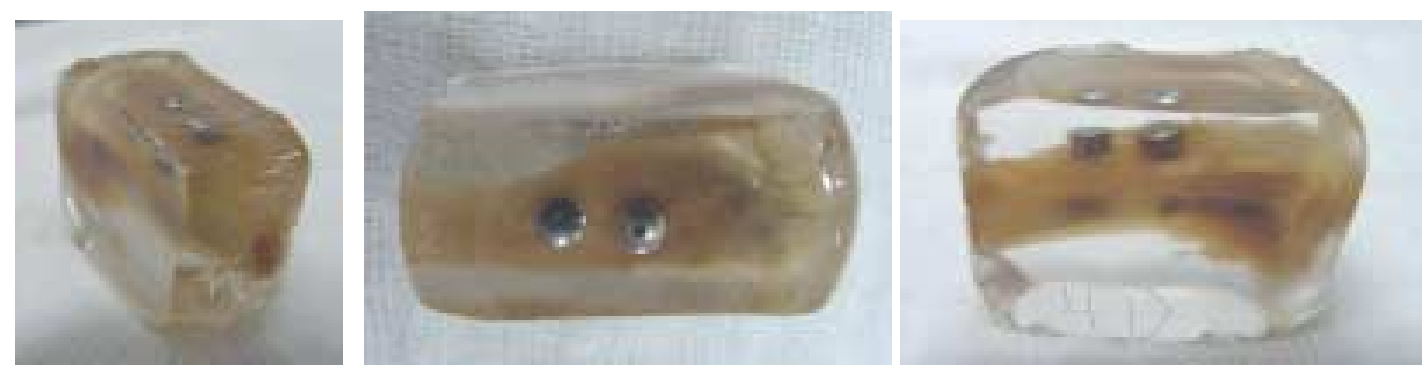

Fig. 5.30-Blocos incluídos em metilmetacrilato com os dois implantes inseridos 
Etapa 4: Cortes transversais dos implantes na máquina EXAKT Alemanha (figuras 5.31 e 5.34). Foram confeccionadas 36 lâminas com implantes, sendo 18 lâminas de material tratado e 18 lâminas de material controle. A lâmina obtida é colocada em uma placa de acrílico e depois submetida a desgastes progressivos para obtenção da lâmina final (figuras 5.33 e 5.33a)
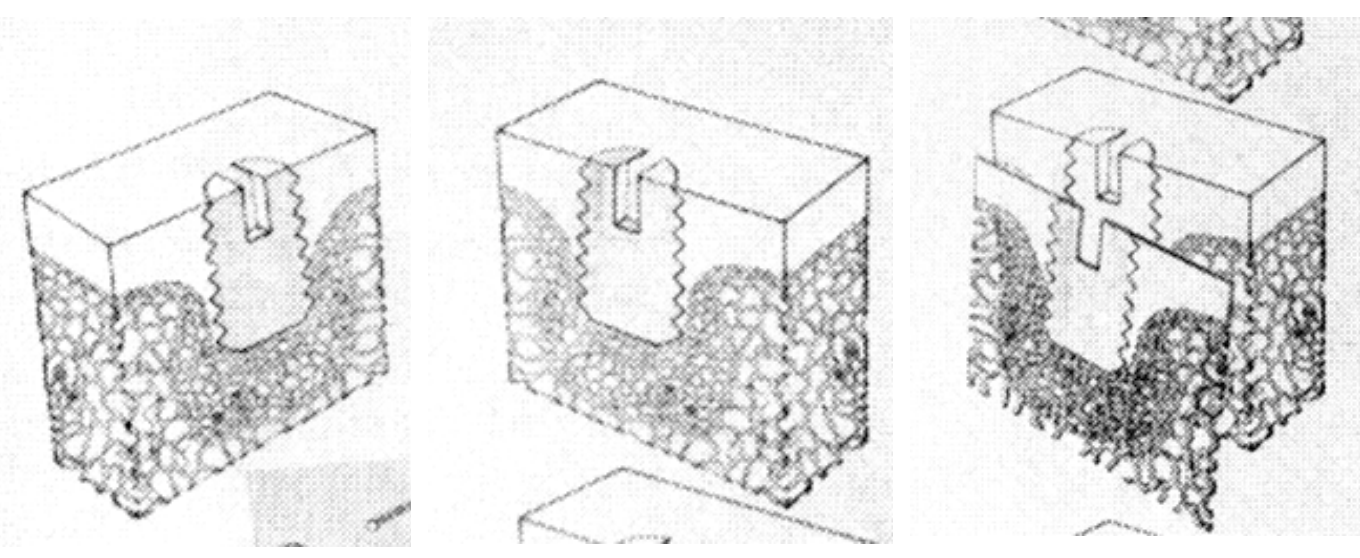

Fig. 5.31 - Desenho do corte do bloco com os implantes colocados.
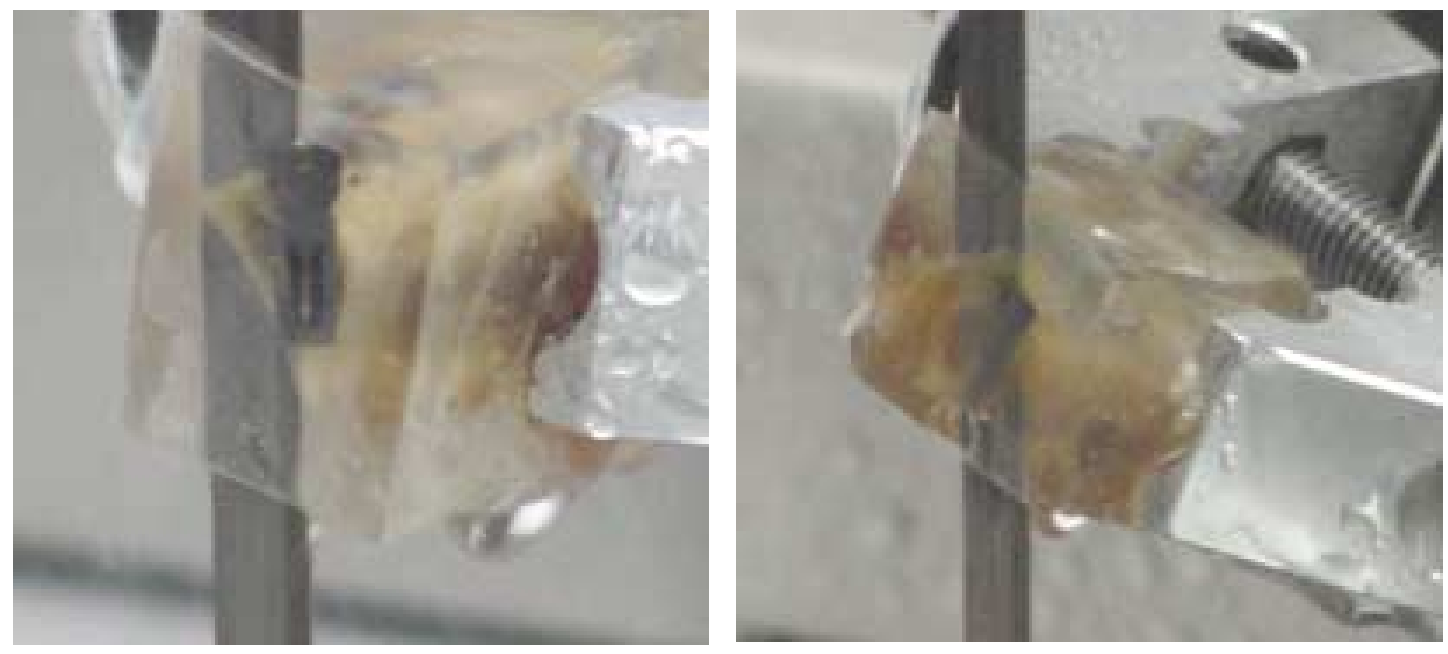

Fig. 5.32 -Blocos incluídos em metilmetacrilato sendo cortados 

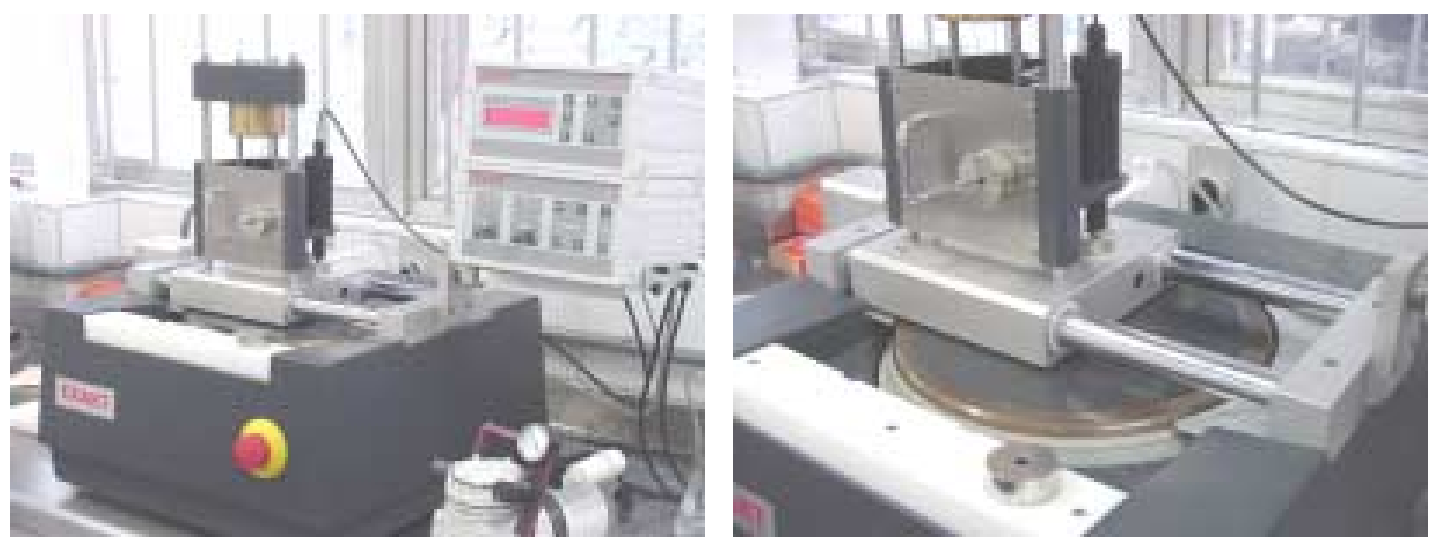

Fig. 5.33 - Máquina para polimento das lâminas

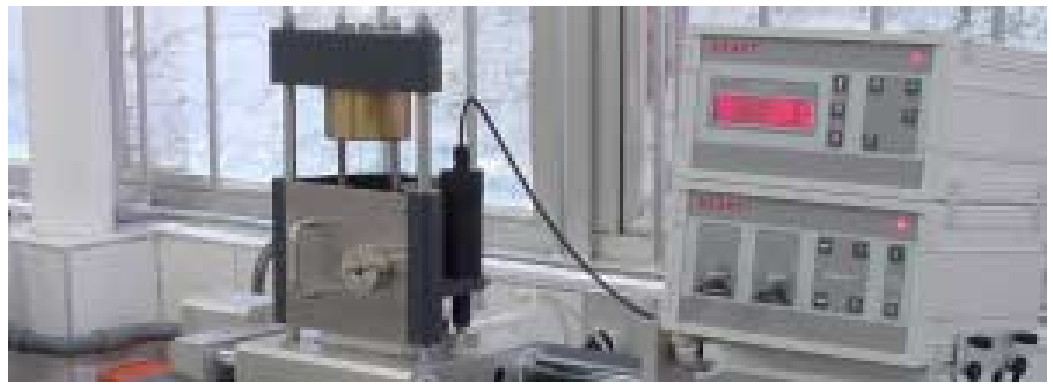

Fig. 5.33a - Display mostrando a quantidade do desgaste que é realizado e quanto ainda falta.

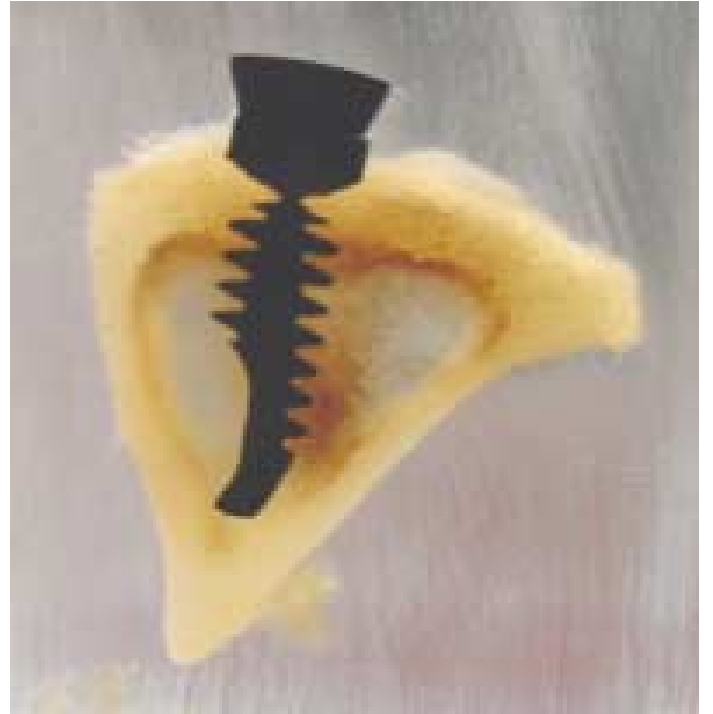

A

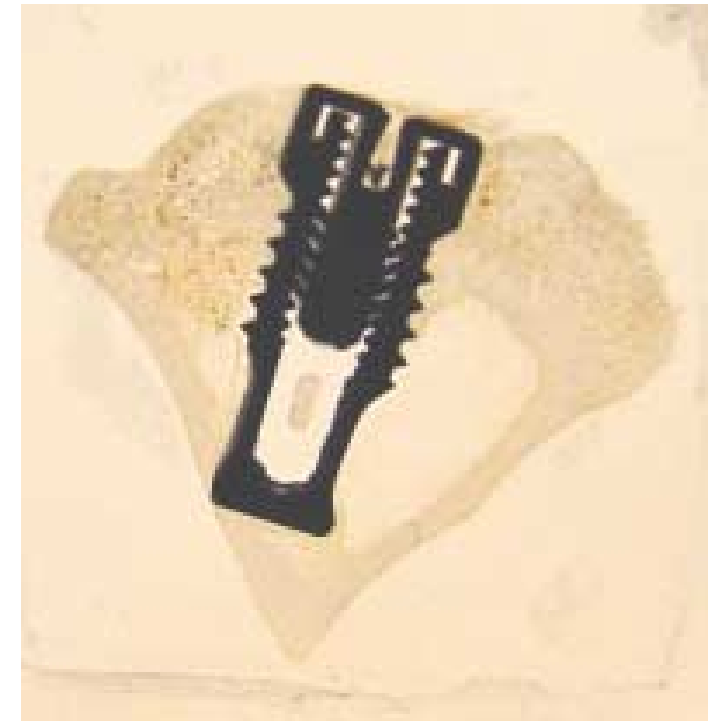

B

Fig. 5.34 - Cortes das tíbias com os implantes A - Corte antes de preparo da lâmina final. B - Corte pronto e polido para estudo de fluorescência 
Etapa 5: Com as lâminas prontas, foi realizado estudo em microscópio óptico de fluorescência, para avaliar a marcação com tetraciclina que aparece em tecido ósseo neoformado. (Figuras 5.35 e 5.36)

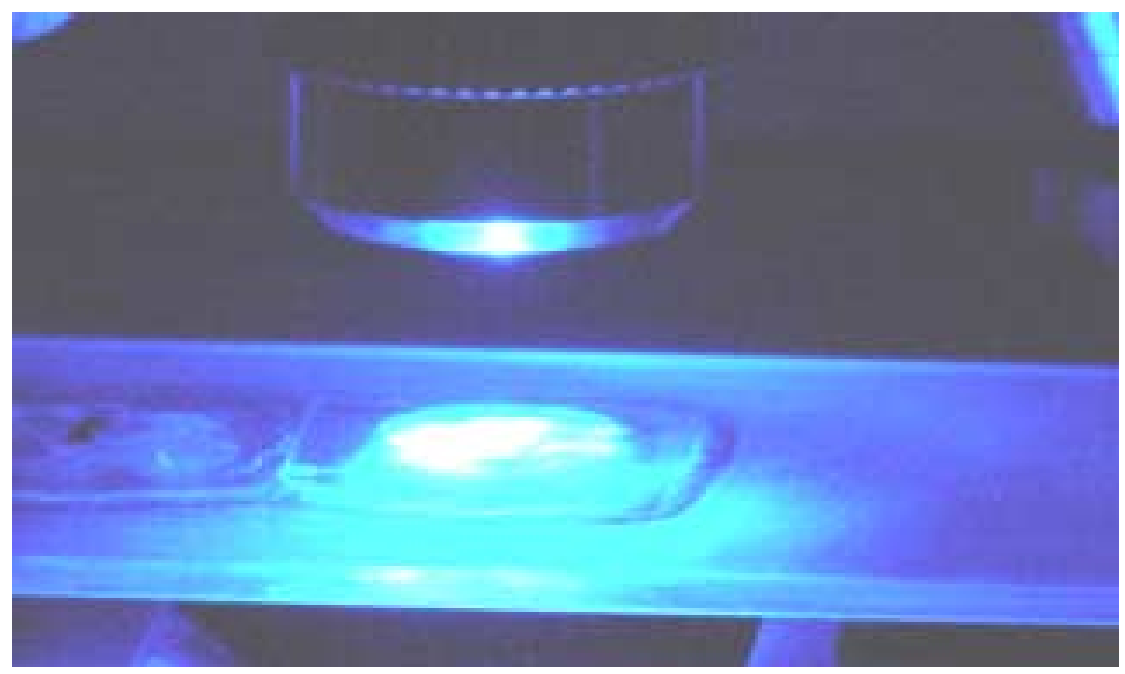

Fig. 5.35 - Vista de uma lâmina sendo estudada sob Fluorescência
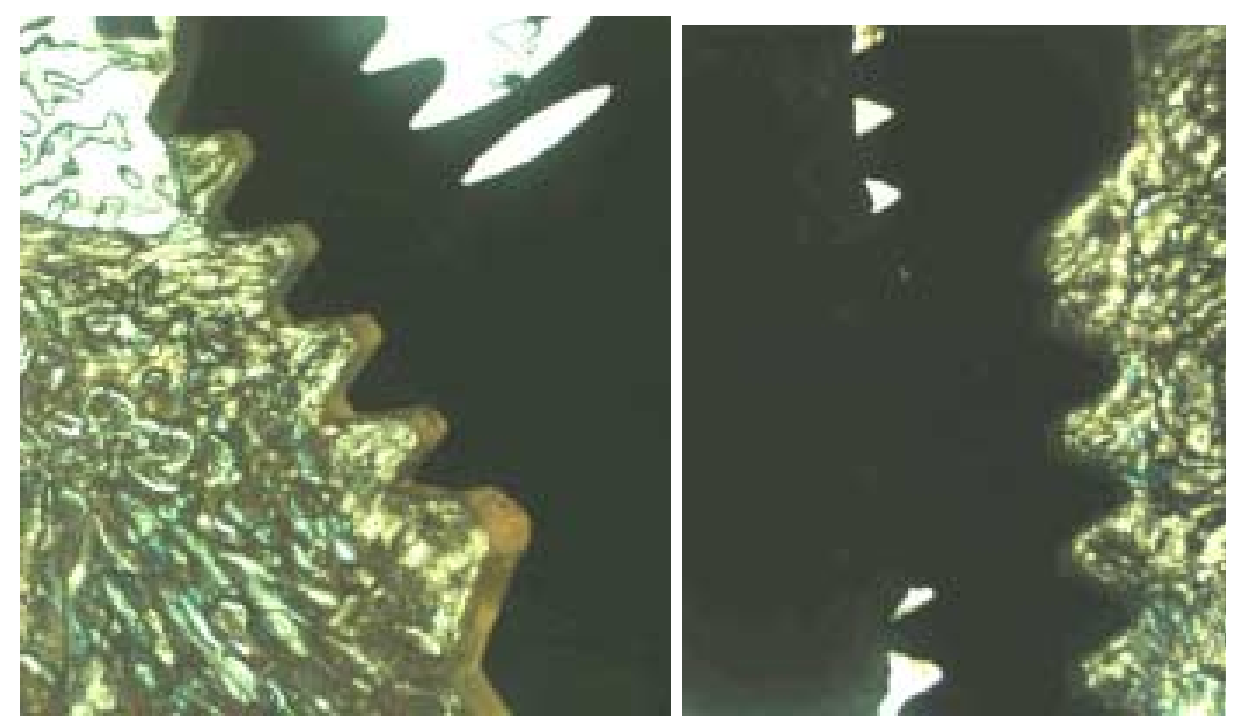

Fig. 5.36 - Vista da histologia através de fluorescência. O tom laranja, presente em pequena quantidade, evidencia o acúmulo de tetraciclina nos tecidos ao redor do implante.

Etapa 6: Avaliação em microscópio óptico de campo claro da fração de área de tecido ósseo não calcificado e de tecido ósseo calcificado presente em duas regiões retangulares junto às espiras do implante, 
utilizando-se um aumento de $4 X$.. Nesta avaliação as lâminas foram coradas com azul de toluidina (Figura 5.38). $O$ tecido não calcificado adquire cor com tons de azul e lilas e o calcificado cor com tons de amarelo. A quantificação (Figuras 5.39 à 5.40 ) foi realizada por um software específico (Image-pro, EUA).

As duas regiões retangulares junto às espiras do implante estão mostradas na fig. 5.37. A lâmina contendo estas duas regiões foi obtida através de um corte coincidente no plano medial e longitudinal do implante. As regiões à esquerda e a direita foram denominadas, respectivamente, de região $S_{E}$ e região $S_{D}$. As regiões foram delimitadas com os seguintes critérios:

- Um dos lados de cada retângulo deveria tangenciar os extremos das espiras da rosca interna do implante (linhas $A B$ e $C D$ ).

- Um dos lados de cada retângulo (linhas EB e DF) deveria tangenciar $\mathrm{O}$ último contato com o osso cortical. $\mathrm{O}$ comprimento das linhas EB e DF é de $2.1 \mathrm{~mm}$. 


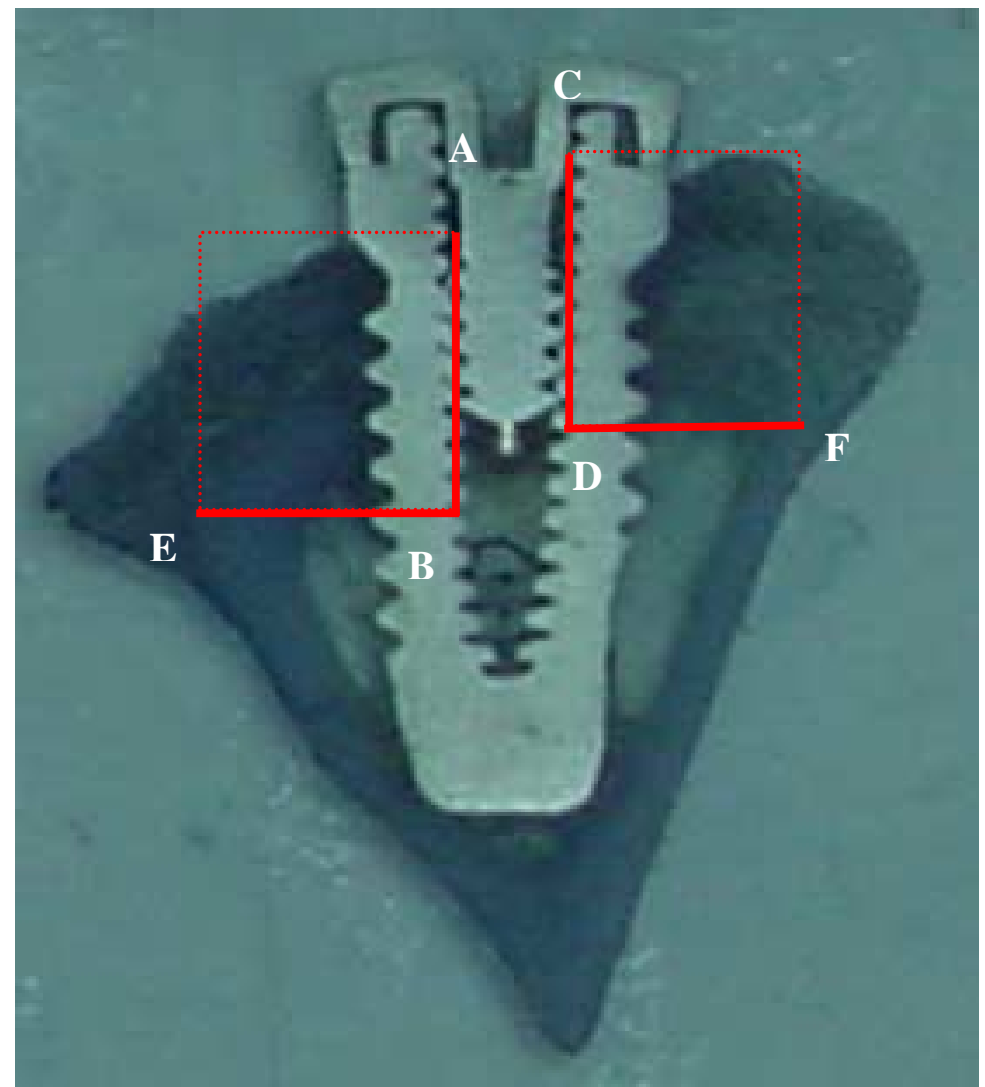

Fig. 5.37 - Regiões escolhidas para a análise histomorfométrica

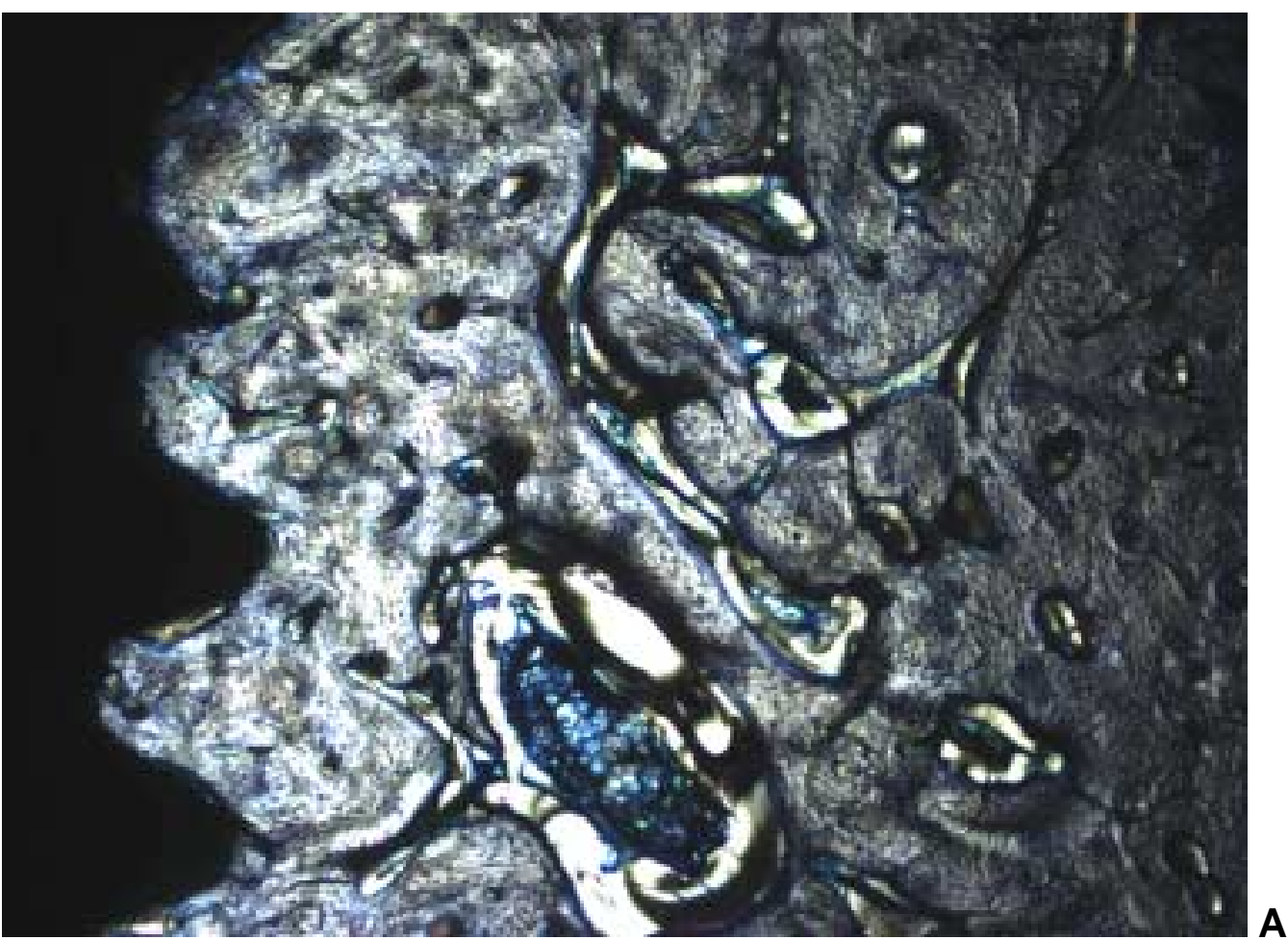




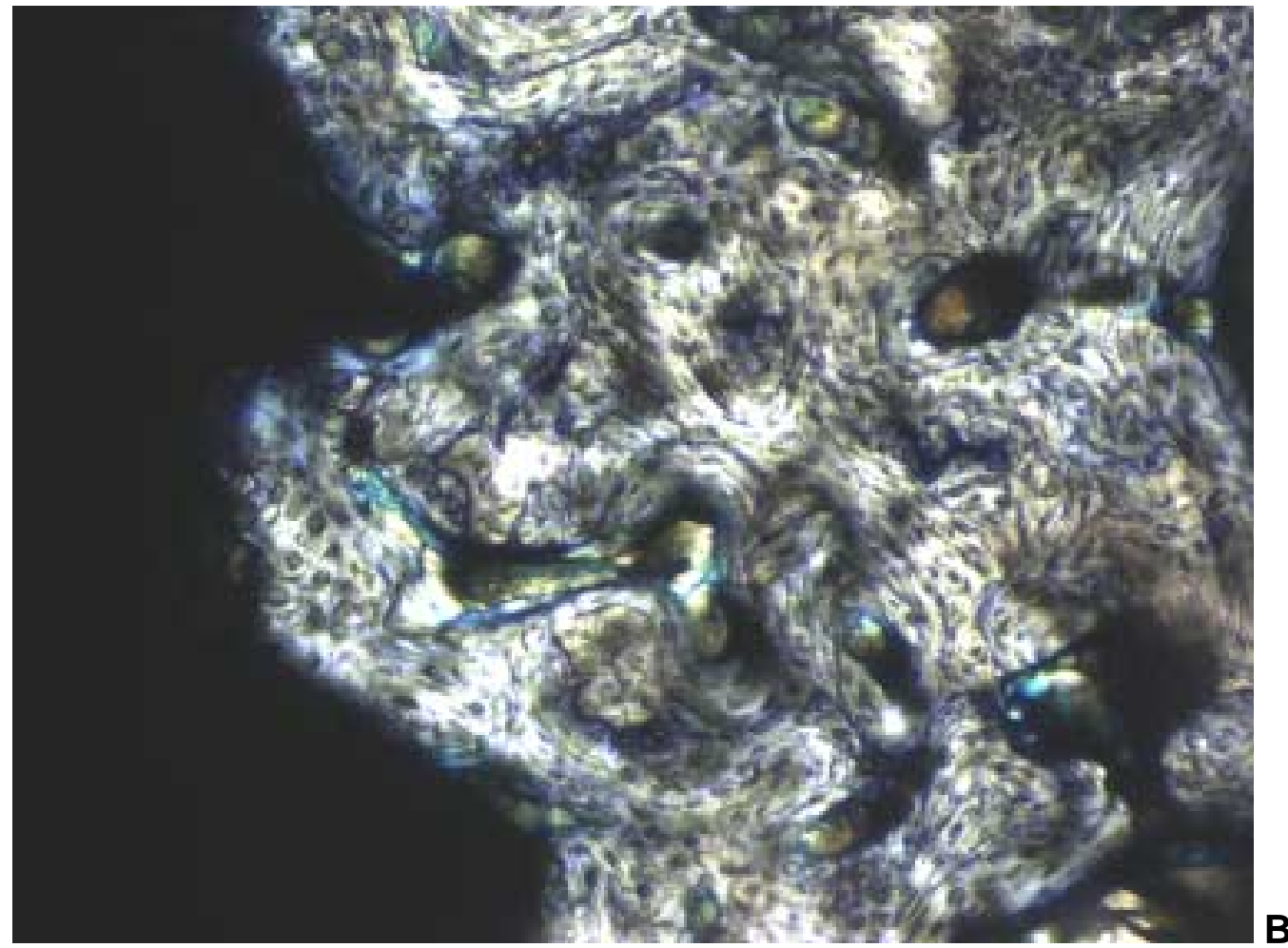

Fig. 5.38 - Histologia através de campo claro, com coloração de azul de toluidina: $(A-4 X)-(B-10 X)$

Os tecidos presentes na lâmina adquirem uma coloração própria após serem corados pelo azul de toluidina. Uma amostra de cada uma destas cores é utilizada pelo software que altera a cor original segundo a escolha do usuário. Na fig. 5.39, por exemplo, a cor original das áreas sem tecido foi alterada para verde. A fig. 5.40 mostra que a cor original do tecido ósseo não calcificado e do tecido calcificado foi alterada para vermelho e amarelo, respectivamente. Após a marcação de cores o software quantifica percentualmente a área corresponde em relação a área total de tecido presente na lâmina. 


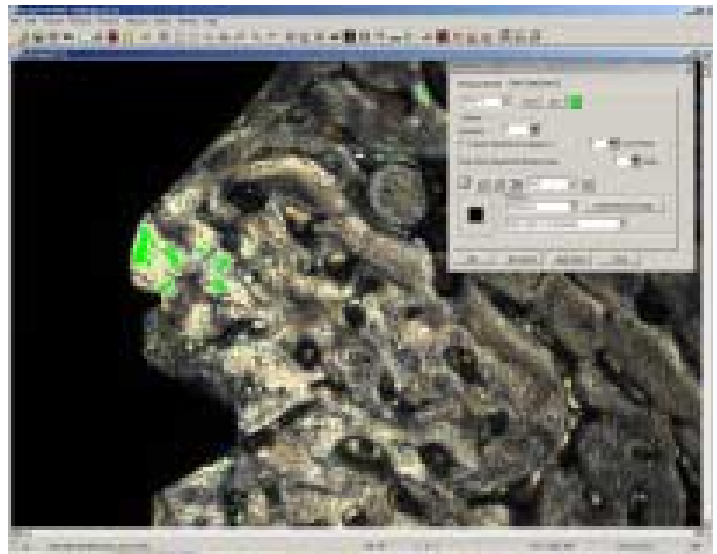

Fig. 5.39 - Imagem adquirida pelo software, sendo submetida a marcação das cores para estudo histomorfométrico.

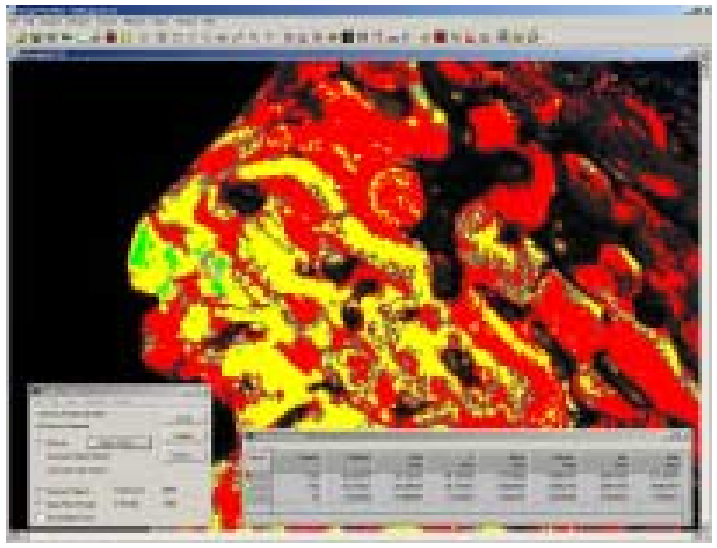

Fig. 5.40 - Imagem com as cores marcadas: vermelho para osso não calcificado, amarelo para osso calcificado e verde para áreas de artefato ou espaços vazios na lâmina.

\subsection{Ensaios Mecânicos}

Ensaios mecânicos de torque e de arrancamento foram utlizados para a avaliação da resistência mecânica da osseointegração dos implantes. Nas tíbias direita e esquerda o implante proximal foi submetido ao ensaio de torque e em seguida o implante distal foi submetido ao ensaio de arrancamento (Figura 5.41). 


\subsubsection{Ensaio de Torque}

Um motor cirúrgico com baixa rotação (modelo BLM 600, V.K. Driller) foi adaptado para realizar a mensuração do torque anti-horário aplicado ao implante até o momento do início de seu movimento (figura 5.42). Através de um acessório desenvolvido para o experimento, 0 implante é conectado a um contra-ângulo (Kavo 120:1) normalmente utilizado em Odontologia para a realização da cirurgia de instalação.

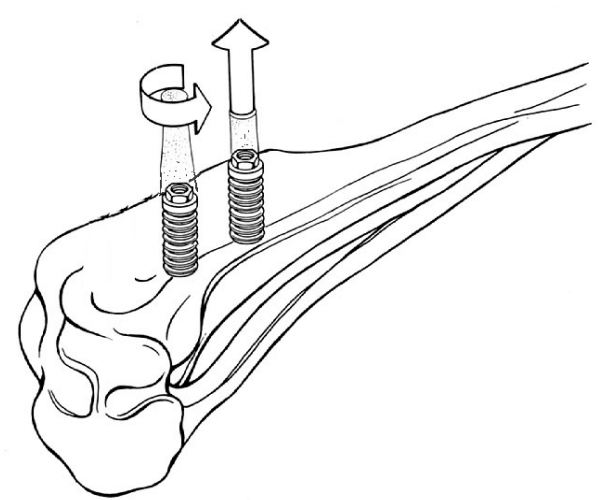

Fig. 5.41 - Testes de torque e arrancamento.

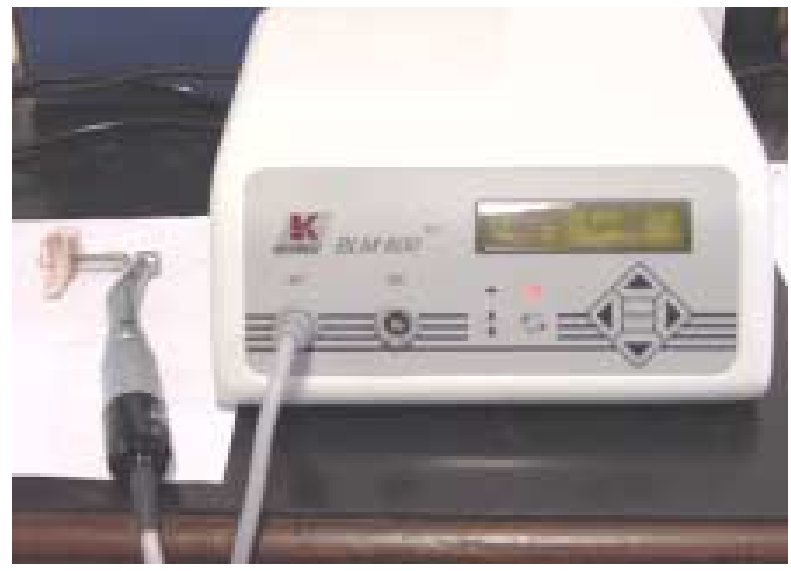

A

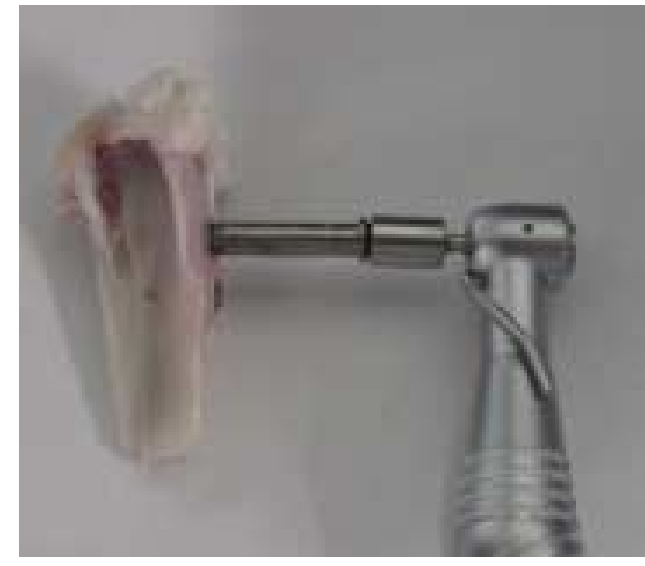

B

Fig. 5.42 - ( A ) - Motor cirúrgico BLM 600 Plus para o teste de torque dos implantes; ( B ) adaptador sobre o implante e o contra-ângulo em utilização (contra-ângulo Kavo 120:1) 
A mensuração do torque de desroqueamento utilizou uma escala de 1 à 256. A correspondência entre esses número e o valor do torque foi determinada através do seguinte procedimento:

- Em uma tábua de madeira foram inseridos implantes com torques medidos pelo motor BLM-600 utilizando a escala de 1 à 256. Os valores medidos para colocação e remoção foram os mesmos.

- $\quad 0$ motor BLM-600 foi acoplado a um torquímetro analógico e os mesmos torques descritos anterioremente foram aplicados. Uma tabela de conversão da escala de 1 à 256 para valores de torque em N/cm pode então ser obtida (tabela 5.4).

\begin{tabular}{|c|c|c|c|c|c|c|c|}
\hline $\begin{array}{l}\text { Dados } \\
\text { do } \\
\text { display }\end{array}$ & $\begin{array}{c}\text { Torque } \\
\mathrm{N} / \mathrm{cm}\end{array}$ & $\begin{array}{l}\text { Dados } \\
\text { do } \\
\text { display }\end{array}$ & $\begin{array}{c}\text { Torque } \\
\mathrm{N} / \mathrm{cm}\end{array}$ & $\begin{array}{l}\text { Dados } \\
\text { do } \\
\text { display }\end{array}$ & $\begin{array}{c}\text { Torque } \\
\mathrm{N} / \mathrm{cm}\end{array}$ & $\begin{array}{l}\text { Dados } \\
\text { do } \\
\text { display }\end{array}$ & $\begin{array}{c}\text { Torque } \\
\mathrm{N} / \mathrm{cm}\end{array}$ \\
\hline 18 & 2 & 58 & 32 & 110 & 62 & 193 & 92 \\
\hline 20 & 5 & 60 & 35 & 114 & 65 & 199 & 95 \\
\hline 22 & 8 & 68 & 38 & 119 & 68 & 206 & 98 \\
\hline 26 & 10 & 70 & 40 & 121 & 70 & 214 & 100 \\
\hline 29 & 12 & 72 & 42 & 128 & 72 & 221 & 102 \\
\hline 35 & 15 & 75 & 45 & 135 & 75 & 233 & 105 \\
\hline 38 & 18 & 78 & 48 & 146 & 78 & 243 & 108 \\
\hline 43 & 20 & 80 & 50 & 153 & 80 & 254 & 110 \\
\hline 45 & 22 & 84 & 52 & 162 & 82 & 255 & 111 \\
\hline 50 & 25 & 92 & 55 & 171 & 85 & 256 & 112 \\
\hline 53 & 28 & 99 & 58 & 179 & 88 & & \\
\hline 55 & 30 & 106 & 60 & 186 & 90 & & \\
\hline
\end{tabular}

5.7.2 Ensaio de Arrancamento

O ensaio foi realizado em uma máquina de teste universal (INSTRON) do Departamento de Engenharia de Materiais, Aeronáutica a e Automobilística da EESC-USP. Através de um acessório especialmente desenvolvido, a tíbia com os implantes foi colocada nas pinças de tração da máquina de ensaio (fig. 5.43 à 5.44). 0 teste de 
arrancamento utilizou uma célula de carga de $500 \mathrm{~N}$, e velocidade de afastamento de $2,0 \mathrm{~mm}$ por minuto.

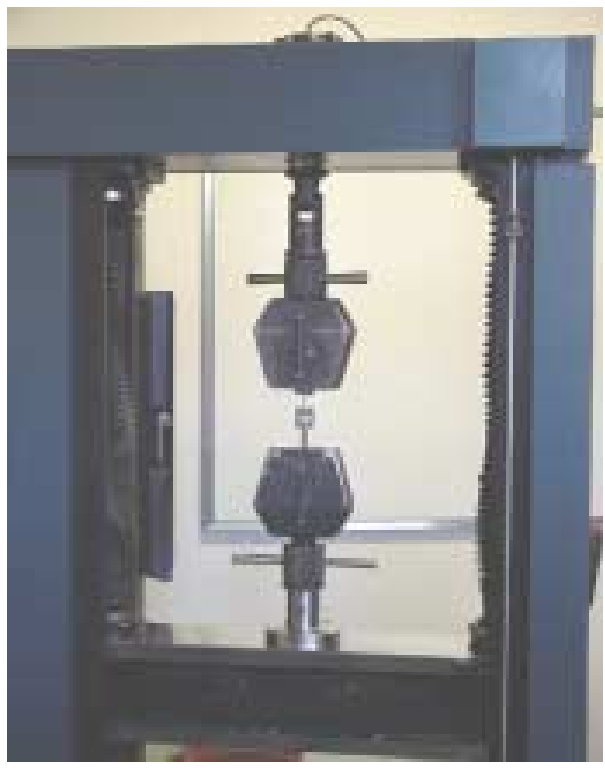

Fig. 5.43- Máquina Instron com o dispositivo desenvolvido para o arrancamento dos implantes
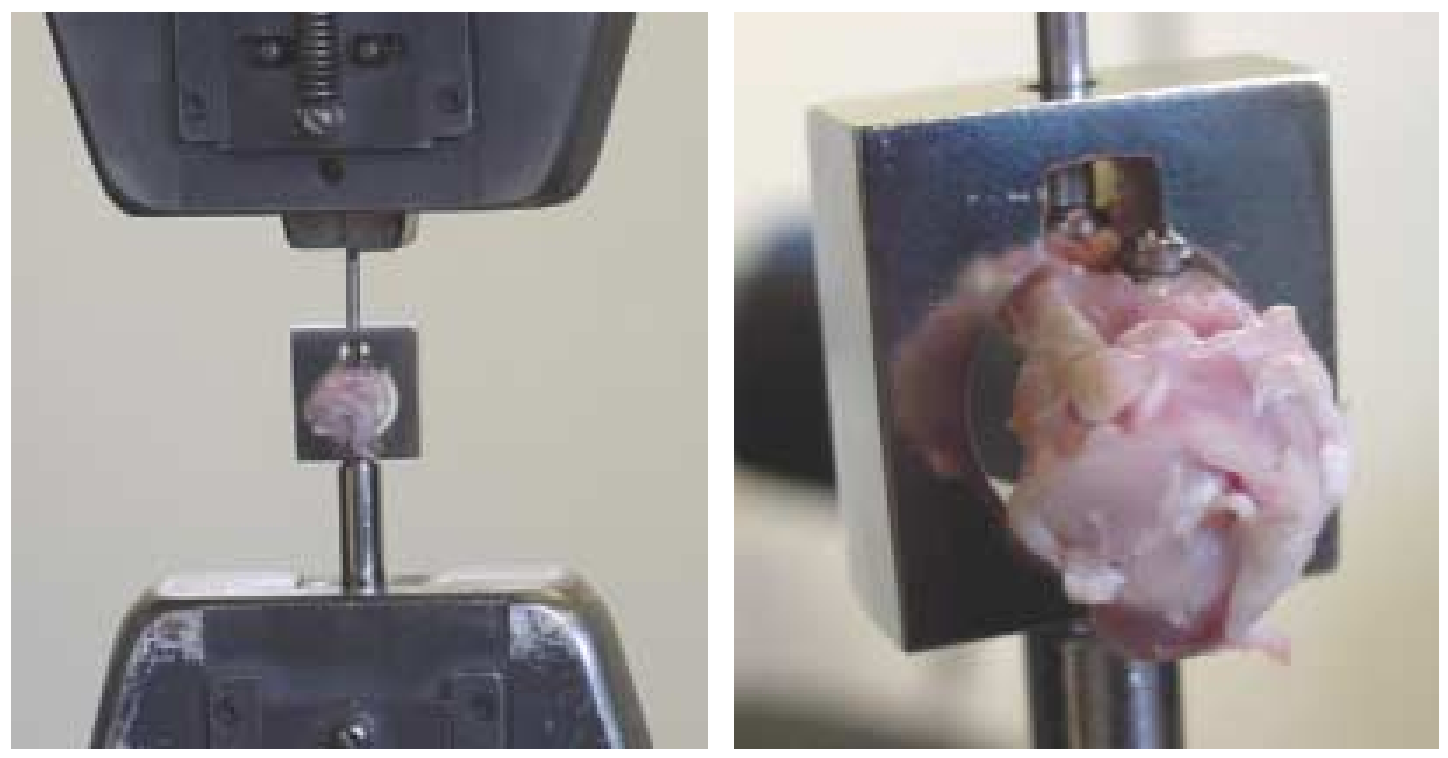

Fig. 5.44- Dispositivo para o arrancamento dos implantes 


\subsection{Análise Estatística}

Os valores do torque de desroqueamento e da força de arrancamento para a retirada dos implantes, e da fração de área de tecido ósseo calcificado e não calcificado ao redor dos implantes, foram análisados estatísticamente para comparação entre os implantes tratados e não tratados pelo ultra-som de baixa intensidade. Foram utilizados um teste paramétrico (teste t pareado de Student) para medidas com pequeno desvio padrão, e um teste não paramétrico (teste pareado de Wilcoxon) para medidas com grande desvio padrão. O nível de significância em ambos os testes foi de $1 \%$. 


\section{Resultados}

\subsection{Ensaios mecânicos}

\subsubsection{Ensaio de Torque}

Na tabela 6.1 estão descritos os valores dos torques para desroqueamento dos implantes. A análise utiliza a média dos valores nos implantes tratados e não tratados por ultra-som, Na tabela 6.2 a análise é intra grupo experimental, e na tabela 6.3 é entre grupos experimentais.

\section{Tabela 6.1 - Torque de Desrosqueamento (N/cm)}

Grupo 1 (3 semanas); Grupo 2 (5 semanas); Grupo 3 (7 semanas)

\begin{tabular}{|c|c|c|c|}
\hline & Animal & (T) Tratado & (T) Controle \\
\hline$\underset{1}{\text { Grupo }}$ & $\begin{array}{l}1 \\
2 \\
3 \\
4\end{array}$ & $\begin{array}{c}19 \\
11,5 \\
10 \\
18,7\end{array}$ & $\begin{array}{l}15,4 \\
20,2 \\
13,5 \\
11,5\end{array}$ \\
\hline \multirow{2}{*}{\multicolumn{2}{|c|}{$\begin{array}{c}\text { Média } \\
\text { Desvio padrão }\end{array}$}} & 14,5 & 15,2 \\
\hline & & 4,7 & 3,7 \\
\hline$\underset{2}{\text { Grupo }}$ & $\begin{array}{l}5 \\
6 \\
7 \\
8\end{array}$ & $\begin{array}{c}93,5 \\
106 \\
25 \\
88\end{array}$ & $\begin{array}{c}24,5 \\
40 \\
86 \\
37,5\end{array}$ \\
\hline \multicolumn{2}{|c|}{ Média } & 78,1 & 47,0 \\
\hline \multicolumn{2}{|c|}{ Desvio padrão } & 36,2 & 26,9 \\
\hline$\underset{3}{\text { Grupo }}$ & $\begin{array}{c}9 \\
10 \\
11 \\
12\end{array}$ & $\begin{array}{c}58 \\
64.5 \\
19,5 \\
81\end{array}$ & $\begin{array}{c}18 \\
12 \\
22,2 \\
19,2\end{array}$ \\
\hline \multicolumn{2}{|c|}{ Média } & $\begin{array}{l}55,8 \\
26,0\end{array}$ & $\begin{array}{c}17,9 \\
4,3\end{array}$ \\
\hline
\end{tabular}


Tabela 6.2 - Análise Estatística / Torque de Desrosqueamento (N/cm) Comparação Intra Grupo Experimental (tratado e controle)

(critério de significância estatistica: $p<0.05$ )

\begin{tabular}{cccc}
\hline Grupo & Teste Estatístico & $p$ & Significância Estatística \\
\hline 1 & t de Student pareado & 0.928 & não \\
2 & Wilcoxon pareado & 0,375 & não \\
3 & Wilcoxon pareado & 0,250 & não \\
\hline
\end{tabular}

Tabela 6.3 - Torque de Desrosqueamento $(\mathrm{N} / \mathrm{cm})$

Comparação Entre Grupos Experimentais

(critério de significância estatistica: $p<0.05$ )

\begin{tabular}{cccc}
\hline \multicolumn{4}{c}{ Controle } \\
\hline Grupo & Teste Estatístico & $\mathrm{p}$ & Significância Estatística \\
\hline 1 e 2 & Wilcoxon pareado & 0,068 & não \\
1 e 3 & t de Student pareado & 0,536 & não \\
2 e 3 & Wilcoxon pareado & 0,068 & não
\end{tabular}

Tratado

\begin{tabular}{cccc}
\hline Grupo & Teste Estatístico & $p$ & Significância Estatística \\
\hline 1 e 2 & Wilcoxon pareado & 0,068 & não \\
1 e 3 & Wilcoxon pareado & 0,068 & não \\
2 e 3 & Wilcoxon pareado & 0,068 & não \\
\hline
\end{tabular}

\subsubsection{Ensaio de Arrancamento}

$\mathrm{Na}$ tabela 6.4 estão descritos os valores da força de arrancamento para retirada dos implantes. A análise utiliza a média dos valores nos implantes tratados e não tratados por ultra-som, Na tabela 6.5 a análise é intra grupo experimental, e na tabela 6.6 é entre grupos experimentais. 
Tabela 6.4 - Ensaio de Força de Arrancamento (Kgf)

Grupo 1 (3 semanas); Grupo 2 (5 semanas); Grupo 3 (7 semanas)

\begin{tabular}{|c|c|c|c|}
\hline \multirow[b]{2}{*}{$\underset{1}{\text { Grupo }}$} & Animal & (T) Tratado & (T) Controle \\
\hline & $\begin{array}{l}1 \\
2 \\
3 \\
4\end{array}$ & $\begin{array}{c}26 \\
30,1 \\
20 \\
23\end{array}$ & $\begin{array}{c}32 \\
25 \\
31 \\
23,5\end{array}$ \\
\hline \multirow{2}{*}{\multicolumn{2}{|c|}{$\begin{array}{c}\text { Média } \\
\text { Desvio padrão }\end{array}$}} & 24,8 & 27,9 \\
\hline & & 4,3 & 4,3 \\
\hline$\underset{2}{\text { Grupo }}$ & $\begin{array}{l}5 \\
6 \\
7 \\
8\end{array}$ & $\begin{array}{c}26 \\
59 \\
37 \\
6\end{array}$ & $\begin{array}{c}30 \\
67 \\
44 \\
7\end{array}$ \\
\hline \multicolumn{2}{|c|}{$\begin{array}{c}\text { Média } \\
\text { Desvio padrão }\end{array}$} & $\begin{array}{c}32 \\
22,1\end{array}$ & $\begin{array}{c}37 \\
25,2\end{array}$ \\
\hline$\underset{3}{\text { Grupo }}$ & $\begin{array}{c}9 \\
10 \\
11 \\
12\end{array}$ & $\begin{array}{c}16 \\
18,5 \\
15 \\
11\end{array}$ & $\begin{array}{c}13 \\
10 \\
11,5 \\
6\end{array}$ \\
\hline & & $\begin{array}{c}15,1 \\
3,1\end{array}$ & $\begin{array}{c}10,1 \\
3,0\end{array}$ \\
\hline
\end{tabular}

Tabela 6.5 - Análise Estatística / Força de Arrancamento (Kgf)

Comparação Intra Grupo Experimental (tratado e controle)

(critério de significância estatistica: $p<0.05$ )

\begin{tabular}{cccc}
\hline Grupo & Teste Estatístico & $p$ & Significância Estatística \\
\hline 1 & t de Student pareado & 0.438 & não \\
2 & Wilcoxon pareado & 0,125 & não \\
3 & t de Student pareado & 0,0275 & sim \\
\hline
\end{tabular}


Tabela 6.6 - Análise Estatística / Força de Arrancamento (Kgf)

Comparação Entre Grupos Experimentais

(critério de significância estatistica: $p<0.05$ )

\begin{tabular}{cccc}
\hline \multicolumn{5}{c}{ Controle } \\
\hline Grupo & Teste Estatístico & $p$ & Significância Estatística \\
\hline 1 e 2 & Wilcoxon pareado & 0,715 & não \\
1 e 3 & t de Student pareado & 0,001 & sim \\
2 e 3 & Wilcoxon pareado & 0,068 & não \\
\hline \multicolumn{5}{c}{ Tratado } \\
\hline Grupo & Teste Estatístico & $p$ & Significância Estatística \\
\hline 1 e 2 & Wilcoxon pareado & 0,414 & não \\
1 e 3 & t de Student pareado & 0,009 & sim \\
2 e 3 & Wilcoxon pareado & 0,144 & não \\
\hline
\end{tabular}

6.1.3 Análise Histomorfométrica

A microscopia óptica sob fluorescência detectou pouca marcação de tetraciclina no tecido ósseo ao redor dos implantes em todos os grupos experimentais. Por esta razão, esta análise não pode ser utilizada para comparação entre implantes tratados e controles.

Na tabela 6.7 estão descritos os valores das frações de área do tecido não calcificado e calcificado presentes nas áreas denominadas de $S_{E}$ e $S_{D}$. As tabelas 6.8, 6.9, 6.10 e 6.11 sumarizam a análise estatística destes valores. Nas tabelas 6.8 e 6.9 a análise é intra grupo experimental. Nas tabelas 6.10 e 6.11 a análise é entre grupos experimentais. 
Tabela 6.7 - Análise histomorfométrica

Grupo 1 (3 semanas); Grupo 2 ( 5 semanas); Grupo 3 (7 semanas)

Tecido 1 - Tecido ósseo não calcificado ; Tecido 2 - Tecido ósseo

calcificado

\begin{tabular}{|c|c|c|c|c|c|}
\hline \multirow[b]{3}{*}{$\underset{1}{\text { Grupo }}$} & \multirow{3}{*}{$\begin{array}{c}\begin{array}{c}\text { Anima } \\
\text { I } \\
\text { (Área) } \\
1-S_{E} \\
1-S_{D} \\
2-S_{E} \\
2-S_{D}\end{array}\end{array}$} & \multicolumn{2}{|c|}{ Tratado (\% da área total) } & \multicolumn{2}{|c|}{$\begin{array}{c}\text { Controle (\% da área } \\
\text { total) }\end{array}$} \\
\hline & & Tecido 1 & Tecido 2 & Tecido 1 & Tecido 2 \\
\hline & & $\begin{array}{l}41,9 \\
34,4 \\
36,7 \\
37,1\end{array}$ & $\begin{array}{l}47,3 \\
50,3 \\
53,3 \\
46,2\end{array}$ & $\begin{array}{l}63,7 \\
72,4 \\
64,3 \\
61,2\end{array}$ & $\begin{array}{l}28,1 \\
17,5 \\
19,4 \\
27,7\end{array}$ \\
\hline \multirow{2}{*}{\multicolumn{2}{|c|}{$\begin{array}{c}\text { Média } \\
\text { Desvio padrão }\end{array}$}} & 37,5 & 49,3 & 65,4 & 23,2 \\
\hline & & 3,2 & 3,2 & 4,9 & 5,5 \\
\hline $\begin{array}{c}\text { Grupo } \\
2\end{array}$ & $\begin{array}{l}3-S_{E} \\
3-S_{D} \\
4-S_{E} \\
4-S_{D}\end{array}$ & $\begin{array}{l}45,8 \\
44,6 \\
42,1 \\
45,3 \\
\end{array}$ & $\begin{array}{l}45,7 \\
49,5 \\
52,9 \\
41,3 \\
\end{array}$ & $\begin{array}{l}50,5 \\
57,1 \\
55,2 \\
58,4 \\
\end{array}$ & $\begin{array}{l}33,7 \\
40,3 \\
44,8 \\
37,4 \\
\end{array}$ \\
\hline & & 44,5 & 47,4 & 55,3 & 39,1 \\
\hline \multicolumn{2}{|c|}{ Desvio padrão } & 1,64 & 4,99 & 3,5 & 4,7 \\
\hline$\underset{3}{\text { Grupo }}$ & $\begin{array}{l}5-S_{E} \\
5-S_{D} \\
6-S_{E} \\
6-S_{D}\end{array}$ & $\begin{array}{l}55,1 \\
12,9 \\
49,3 \\
26,7\end{array}$ & $\begin{array}{l}30,3 \\
84,2 \\
49,5 \\
42,7\end{array}$ & $\begin{array}{l}62,9 \\
57,3 \\
54,3 \\
53,1\end{array}$ & $\begin{array}{l}31,9 \\
40,1 \\
33,2 \\
42,3\end{array}$ \\
\hline \multirow{2}{*}{\multicolumn{2}{|c|}{$\begin{array}{c}\text { Média } \\
\text { Desvio padrão }\end{array}$}} & 36,0 & 51,7 & 56,9 & 36,9 \\
\hline & & 19,7 & 23,1 & 4,4 & 5,1 \\
\hline
\end{tabular}

Tabela 6.8 - Análise Estatística / Histomorfometria (Osso Não Calcificado)

Comparação Intra Grupo Experimental (tratado e controle) (critério de significância estatística: $p<0.05$ )

\begin{tabular}{cccc}
\hline \multicolumn{4}{c}{ Controle } \\
\hline Grupo & Teste Estatístico & $\mathrm{p}$ & Significância Estatística \\
\hline 1 & t de Student Pareado & 0,004 & sim \\
2 & t de Student Pareado & 0,0013 & sim \\
3 & Wilcoxon pareado & 0,068 & não \\
\hline
\end{tabular}


Tabela 6.9 - Análise Estatística / Histomorfometria (Osso Calcificado) Comparação Intra Grupo Experimental (tratado e controle) (critério de significância estatística: $p<0.05$ )

\begin{tabular}{cccc}
\hline \multicolumn{5}{c}{ Controle } \\
\hline Grupo & Teste Estatístico & $p$ & Significância Estatística \\
\hline 1 & t de Student Pareado & 0,008 & sim \\
2 & t de Student Pareado & 0,016 & sim \\
3 & Wilcoxon Pareado & 0,273 & não \\
\hline
\end{tabular}

Tabela 6.10 - Análise Estatística / Histomorfometria (Osso Não Calcificado)

Comparação Entre Grupos Experimentais (critério de significância estatística: $p<0.05$ )

\begin{tabular}{cccc}
\hline \multicolumn{5}{c}{ Controle } \\
\hline Grupo & Teste Estatístico & $p$ & Significância Estatística \\
\hline 1 e 2 & t de Student pareado & 0,035 & sim \\
1 e 3 & t de Student pareado & 0,064 & não \\
2 e 3 & t de Student pareado & 0,703 & não \\
\hline \multicolumn{5}{c}{ Tratado } \\
\hline Grupo & Teste Estatístico & $p$ & Significância Estatística \\
\hline 1 e 2 & t de Student pareado & 0,016 & sim \\
1 e 3 & Wilcoxon pareado & 1.0 & não \\
2 e 3 & Wilcoxon pareado & 0,465 & não \\
\hline
\end{tabular}




\begin{tabular}{cccc} 
Tabela 6.11 - $\begin{array}{c}\text { Análise Estatística / Histomorfometria (Osso Calcificado) } \\
\text { Comparação Entre Grupos Experimentais } \\
\text { (critério de significância estatistica: } p<0.05)\end{array}$ \\
\hline \multicolumn{5}{c}{ Controle } \\
\hline Grupo & Teste Estatístico & $p$ & Significância Estatística \\
\hline 1 e 2 & t de Student pareado & 0,047 & sim \\
1 e 3 & t de Student pareado & 0,038 & sim \\
2 e 3 & t de Student pareado & 0,572 & não \\
\hline \multicolumn{5}{c}{ Tratado } \\
\hline Grupo & Teste Estatístico & $p$ & Significância Estatística \\
\hline 1 e 2 & t de Student pareado & 0,156 & não \\
1 e 3 & Wilcoxon pareado & 0,715 & não \\
2 e 3 & Wilcoxon pareado & 1,0 & não \\
\hline
\end{tabular}

A observação das lâminas utilizadas na análise histomorfométrica mostrou que as espiras dos implantes, tratados ou não tratados por ultra-som, em contato com o osso cortical da tíbia dos animais, foram totalmente preenchidas por tecido ósseo. Esta região de contato foi a região utilizada na determinação da fração em área de tecido calcificado ou não-calcificado, existente junto às espiras dos implantes, conforme mostrado na fig. 5.37. 


\section{Discussão}

O início das investigações sobre os efeitos do ultra-som de baixa intensidade na osseointegração de implantes metálicos é muito recente. As publicações pioneiras são de Tanzer e coloboradores (1996 e 2001) e utilizaram implantes porosos visando aplicações em ortopedia. Em ambos os estudos a fração de área óssea presente no interior dos implantes foi quantificada. Não foi avaliada o estágio de mineralização do osso formado (osso calcificado ou não calcificado) e não foram realizados testes de resistência mecânica nos implantes. Foram estabelecidos grupos experimentais com implantes tratados e não-tratados por ultra-som.

No primeiro estudo, implantes cilindricos porosos e sinterizados de titânio foram colocados bilateralmente no fêmur de cães $(n=12)$. Os grupos experimentais tiveram duração de 2, 3 e 4 semanas. A intensidade do ultra-som foi de $30 \mathrm{~mW} / \mathrm{cm}^{2}$. A fração de área óssea em seções longitudinais nos implantes tratados foi sempre maior $(25,1 \%$, $39,6 \%$ e $44,3 \%$, respectivamente) do que nos implantes não tratados $(20,8,34,1 \%$ e 38,2$)$. As significâncias estatísticas obtidas foram $\mathrm{p}=0.08, \mathrm{p}=0.06$ e $\mathrm{p}=0.3$, respectivamente. A profundidade da penetração óssea foi maior nos implantes tratados $(80 \%, 74 \%$ e $90 \%)$ do que nos não tratados $(65 \%, 68 \%$ e $79 \%)$. A significância estatística obtida foi $p \geq 0.2$. Os autores concluiram que os resultados preliminares sugerem um aumento na ósseointegração através do ultra-som com possíveis aplicações na fixação de implantes com revestimento poroso usados em ortopedia. 
No segundo estudo implantes cilindricos porosos e sinterizados de tântalo foram colocados bilateralmente na ulna de cães $(n=6)$ na região intramedular. A duração do experimento foi de 6 semanas. A intensidade do ultra-som foi de $250 \mathrm{~mW} / \mathrm{cm}^{2}$. A fração de área óssea em seções transversais foi em média $119 \%$ maior $(p<0.001)$ nos implantes tratados. Os autores concluiram que a osseointegração em implantes porosos intramedulares foi substancialmente aumentada pelo ultrasom, devendo-se investigar o seu efeito em próteses para artroplastia implantadas sem o uso de cimento.

Os dois estudos anteriormente citados são as únicas referências sobre os efeitos do ultra-som, com parâmetros elétricos e acústicos similares aos utilizados no tratamento de fraturas, na osseointegração de implantes metálicos. No segundo trabalho de Tanzer et al. (2001), no entanto, a intensidade acústica foi 8,3 maior que a normalmente utilizada. Os resultados foram significativamene melhores do que os do primeiro estudo, sugerindo que a otimização do parâmetro intensidade deve ser investigada.

$\mathrm{Na}$ investigação aqui descrita, foram usados implantes dentais de titânio com rugosidade superficial produzida por ataque químico. Implantes com esta característica são largamente utilizados em odontologia. $O$ estudo é pioneiro por investigar os efeitos ultra-som de baixa intensidade, com parâmetros elétricos e acústicos idênticos aos utilizados no tratamento de fraturas, na osseointegração de implantes para uso em odontologia. Os estudos de Tanzer et al. (1996 e 2001), inspiraram a realização desta investigação. A comparação de resultados, no entanto, é limitada pelo fato dos implantes no estudo aqui descrito não serem porosos.

$\mathrm{Na}$ incerteza sobre o período em que a osseointegração nos 
implantes deveria ser analisada, utilizando como modelo experimental a colocação de implantes dentais em tíbia de coelho, optou-se pelas durações de 3, 5 e 7 semanas, por serem mais tardias que a utilizada no primeiro estudo de Tanzer et al. (1996)

Um estudo avaliou se o ultra-som com os mesmos parâmetros que os do tratamento de fraturas, mas com intensidade três vezes maior, durante $\mathbf{3 0}$ horas, afetaria a composição de placas de fixação ortopédicas de aço inoxidável AISI 316-L em um meio fisiológico (PMA900009, 2000). Após análise metalográfica não foram observadas alterações nas placas estimuladas quando comparadas às não estimuladas. $O$ ultra-som de baixa intensidade, portanto, não prejudica a integridade do material de implantes ortopédicos, mesmo após 30 horas de exposição contínua. Com base neste estudo, admitiu-se nesta investigação que alterações em implantes de titânio seriam tambem inexistentes.

Ao contrário dos estudos de Tanzer et al. (1996 e 2001), nesta investigação foi realizada a análise da resistência mecânica dos implantes tratados ou não tratados por ultra-som. A análise histomorfométrica permitiu avaliar qualitativamente (osso calcificado e não calcificado) e quantitativamente o tecido ósseo formado ao redor dos implantes.

Os resultados histomorfométricos (tabela 6.7) mostram que nos implantes tratados por ultra-som durante 3 e 5 semanas há mais tecido ósseo calcificado formado junto as espiras do que nos implantes não tratados. A análise estatística intra grupos experimentais mostrou que este aumento é estatisticamente significante. A fração média de área deste tecido é tambem maior nos implantes tratados por 7 semanas, mas não há significância estatística. A análise estatística entre grupos experimentais revela que a fração de tecido ósseo calcificado nos 
implantes tratados durante 3,5 e 7 semanas permaneceu constante, pois não foram estatisticamente significantes as diferenças nas frações médias medidas.

Nos implantes não tratados por ultra-som durante $\mathbf{3}$ e $\mathbf{5}$ semanas há mais tecido ósseo não calcificado formado junto as espiras do que nos implantes tratados. A análise estatística intra grupos experimentais mostrou que este aumento é estatisticamente significante. A fração média de área deste tecido é tambem maior nos implantes não tratados durante 7 semanas, mas não há significância estatística. A análise estatística entre grupos experimentais revela que a fração de tecido ósseo não calcificado nos implantes não tratados diminuiu de 3 para 5 semanas $(p=0.035)$, mas manteve-se constante entre 5 e 7 semanas $(p=0.703)$.

Uma maior qualidade de tecido ósseo está associada a uma maior quantidade de tecido ósseo calcificado porque este deve apresentar maior resistência mecânica que o tecido não calcificado.

Os resultados dos ensaios mecânicos não confirmaram esta expectativa. A análise estatística intra grupos experimentais mostrou que não é estatisticamente significante a diferença na resistência mecânica entre implantes tratados e não tratados por ultra-som durante 3, 5 e 7 semanas, quando avaliada por torque de desrosqueamento e força de arrancamento (tração).

Os valores médios do torque de desrosqueamento dos implantes tratados e não tratados após 3 semanas são $14,5 \mathrm{Ncm}$ e $15,2 \mathrm{Ncm}$, respectivamente. Estes valores crescem após 5 semanas, sendo maior nos implantes tratados (78,1 $\mathrm{Ncm}$ e 47,0 Ncm, respectivamente). Após 7 semanas os valores são maiores nos implantes tratados $(55,8 \mathrm{Ncm}$ e $17,9 \mathrm{Ncm}$, respectivamente), mas menores que os obtidos com 5 semanas. 
Os valores médios da força de arrancamento dos implantes tratados e não tratados após 3 semanas são $24,8 \mathrm{Kgf}$ e $27,9 \mathrm{Kg}$, respectivamente. Estes valores crescem após 5 semanas, sendo maior nos implantes não tratados (32,1 Kgf e $37,0 \mathrm{Kgf}$, respectivamente). Após 7 semanas os valores são maiores nos implantes tratados $(15,1$ Kgf e $10,1 \mathrm{Kgf}$, respectivamente), mas menores que os obtidos com 5 semanas.

As espiras dos implantes, tratados ou não tratados por ultrasom, em contato com o osso cortical da tíbia dos animais, foram totalmente preenchidas por tecido ósseo. Esta região de contato foi a utilizada na determinação da fração em área de tecido calcificado ou não-calcificado existente junto às espiras dos implantes.

A análise histomorfométrica demonstrou que houve um aumento do tecido ósseo calcificado junto às espiras superiores dos implantes tratados durante 3, 5 e 7 semanas, mas com significância estatística apenas nos tratados durante 3 e 5 semanas.

Os ensaios mecânicos, por torque de desroqueamento ou força de arrancamento, demonstraram que não há significância estatística intra grupos e entre grupos. Houve significância apenas nos resultados do ensaio de força de arrancamento entre os implantes tratados ou não-tratados com 3 e 7 semanas. Essa significância foi consequência da diminuição do valor médio da força de arrancamento após 7 semanas. A causa desta diminuição é desconhecida.

Os resultados sugerem que a qualidade do tecido ósseo, caracterizada pela maior quantidade de osso calcificado, no modelo 
experimental investigado, é estimulada pelo ultra-som de baixa intensidade. A resistência mecânica dos implantes, no entanto, parece ser mais dependente da quantidade de tecido ósseo presente nas espiras do que da qualidade do mesmo. 


\section{Conclusão}

Implantes comerciais dentais de titânio com superfície tratada por subtração ácida, implantados em tíbia de coelho, quando tratados por ultra-som de baixa intensidade com os mesmos parâmetros utilizados no tratamento de fraturas, apresentaram em regiões que incluem áreas ao redor e dentro das espiras, após 3 e 5 semanas, maior quantidade de osso calcificado que implantes não tratados. Não houve significância estatística na quantidade de osso calcificado, entre implantes tratados e não tratados, após 7 semanas.

As espiras dos implantes tratados e não-tratados, em contato com o osso cortical da tíbia, foram totalmente preenchidas por tecido ósseo após 3, 5 e 7 semanas de colocação dos implantes.

Os ensaios mecânicos de torque por desroqueamento e força de arrancamento não detectaram diferença na resistência mecânica entre implantes tratados e não-tratados por ultra-som após 3, 5 e 7 semanas. A resistência mecânica dos implantes parece ser mais dependente do preenchimento das espiras por tecido ósseo do que da fração óssea de osso calcificado existente nas espiras e nas proximidades das mesmas. 


\section{Proposta de Trabalhos Futuros}

Os estudos de Tanzer e colaboradores (1996 e 2001) na área da ortopedia, que demonstram maior osseointegração de implantes porosos sinterizados de titânio ou tântalo, quando tratados por ultrasom de baixa intensidade, não apresentam similares na área da odontologia.

Atualmente a grande maioria dos implantes comerciais de titânio para uso odontológico apresentam superfície lisa ou com tratamento. No entanto, existe no mercado internacional um implante de titânio que apresenta um corpo sinterizado (Astratech - EUA). Este implante ainda não esta disponível comercialmente no Brasil. Com base nos estudos de Tanzer e nos resultados aqui descritos, sugere-se uma investigação sobre os efeitos do ultra-som de baixa intensidade na osseointegração desses implantes. 
10. Referências Bibliográficas

Abendschein WF; Hyatt GW, (1972) Ultrasonics and physical properties of healing bone. J Trauma 12:4 297-301.

Adell R; Eriksson B; Lekholm U; Bränemark PI; Jemt T, (1990) A longterm follow-up of osseointegrated implants in the treatment of totally edentulous jaws. Int. J. Oral Maxillofac Implants, v. 5, 347-59.

Albrektsson T; Branemark, P-I; Hasson, HA; Lindstrom J, (1981) Osseointegrated titanium implants. requirements for ensuring a Long-lasting, direct Bone-to-implant anchorage in man Acta Orthop Scan v52 155-170

Albrektsson T; Hasson, HA (1986) An Ultrastructural characterization of the interface between bone and sputtered titanium or stainless steel surfaces. Biomaterials, v7, 201-5.

Albrektsson, T; Albrektsson, B, (1987) Osseointegration of bone implants: a review of an alternative mode of fixation. Acta Orthop Scand, v58, 567-77.

Albrektsson, T; Sennerby, L (1990) Direct bone anchorage of implants: clinical and experimental considerations of the concept of osseointegration Int J Prosthodont v3 30-41

Anastácio MADJ, Duarte LR. (2000) Reparação Epitelial em Úlceras Vasculares após Estimulação do Ultra-Som Pulsado de Baixa Intensidade. Dissertação de Mestrado, Interunidades Bioengenharia (EESC/FMRP/IQSC-USP).

Arai T, Ohashi T, Daitoh Y, Incue S. (1993) The effect of ultrasound stimulation on disuse osteoporosis. 13th Annual Meeting of Bioelectrical Repair and Growth Society, Dana Point, CA, USA,.

Arvidson K; Bystedt H; Ericsson I (1990) Histometric and ultrastructural studies of tissues surrounding Astra dental implants in dogs. Int $\mathrm{J}$ Oral Maxillofac Implants 5:2 127-34

Aspray TJ; Francis RM; Thompson A; Quilliam SJ; Rawlings DJ; Tyrer SP (19980 Comparison of ultrasound measurements at the heel between adults with mental retardation and control subjects. Bone 22:6 665-8

Azuma $\mathrm{Y}$, Ito $\mathrm{M}$, Harada $\mathrm{Y}$, Takagi $\mathrm{H}$, Ohta $\mathrm{T}$, Komoriya $\mathrm{K}$, Jingushi S (1999) Accelerating effect of low-intensity pulsed ultrasound on rat femoral fracture healing: relationship between the timing of pulsed ultrasound treatment and the healing accelerating action. 45th Annual Meeting, Orthopaedic Research Society, USA.

Azuma, Y., Ito, M., Harada, Y., Takagi, H., Ohta, T., Komorya, K, and Jingushi, S.: (2001) Low-intensity pulsed umtrasound accelerates rat femoral fracture healing by acting on various cellular reactions involved in fracture repair. J. Bone and Min Res., 16(4):671-680. 
Bachner EJ, Klion M, Caruana SM, Kaufman JJ, Nasser P, Siffert RS, Pilla AA. (1987) Ultrasonic effects on fresh fracture repair - A study in two rabbit models, Transactions of the Seventh Annual Meeting of the Biolectrical Repair and Growth Society, October 11-14, Toronto, Canada, Volume VII, pg. 3.

Bachner EJ, Klion MJ, Nasser P, Siffert RS, Pilla AA. A fracture healing model suitable for torsional mechanical testing. 34th Annual Meeting, Orthopaedic Research Society, February 1-4, Atlanta, Georgia, USA, 1988.

Baggs AC: Portable bone-growth stimulators go domestic in USA The Lancet, 347 (25): 1474, 1996

Basset, CAL Effect of force on skeletal tissues In: Physiological Basis Of Rehabilitation Medicine, NY, Sauders, Cap. 16, 286-316, 1971.

Basset, CAL; Becker, RO Generation of eletric potentials by bone in response to mechanical stress. Science, v137, 1063-4, 1962.

Bränemark PI, Zarb G, Albrektsson T Tissue-integrated Prostheses. Osseointegration in Clinical Dentistry, Chicago. Quintessence Publishing, 1985

Bränemark PI; Hansson, BO; Adell, R; Breine, U; Lindstrom, J; Hallen, O; Ohman, A Osseointegrated dental implants in the treatment of the edentulous jaw. Experience from a 10-year period. Scand $\mathbf{J}$ Plast Reconstr Surg 11: Suppl.16, 1-32, 1977.

Bränemark R, Skalak R, Bränemark PI Osseointegration and rigid fixation. In Yaremchuk MJ, Gruss JS, Manson ON (eds): Rigid Fixation of the craniomaxilofacial skeleton. Stoneham, MA, Butterworth-heinemann Publishing, 163-175, 1992.

Bränemark R; Breine, U; Adell, R Hasson, BO, Lindstrom, J; Ohlsson, A Intra-osseous anchorage of dental prostheses. Scan J Plast Reconstr Surg, v3, 81-100, 1969.

Bränemark R; Ohrnell LO; Skalak R; Carlsson L; Bränemark PI Biomechanical characterization of osseointegration: an experimental in vivo investigation in the beagle dog. J Orthop Res, Jan, 16(:1) 61-9, 1998

Brighton, CT The treatment of non-union with electricity. J Bone Joint Surg v.63A, 847-51, 1981.

Brosh T; Persovski Z; Binderman I Mechanical properties of boneimplant interface: an in vitro comparison of the parameters at placement and at 3 months. Int J Oral Maxillofac Implants 1995 10:6 729-35

Buser D; Nydegger T; Hirt HP; Cochran DL; Nolte LP Removal torque values of titanium implants in the maxilla of miniature pigs. Int $\mathbf{J}$ Oral Maxillofac Implants 1998 13:5 611-9

Cardoso AM; Duarte LR; Ferrario I. Ultrassound effects at the cromossomal level. Thesis, Graduate Bioengeneering Program, University of São Paulo, Brazil, 1994.

Carr AB; Beals DW; Larsen PE Reverse-torque failure of screw-shaped implants in baboons after 6 months of healing. Int $\mathbf{J}$ Oral Maxillofac Implants 1997 Sep, 12:(5) pags. 598-603 
Choffie, M., Duarte, L.R.: Low-intensity ultrasound and effects on ununited fractures. Read at the Orthopaedic Health Conference, University Hospital, University of Sâo Paulö, Brazil, June 15, 1994

Cochran GVB; Pawluk RJ; Basset CAL: Electromechanical characteristics of bone under physiologic moisture conditions. Clin Orthoped, 58: 249-270, 1968

Colella SM, Miller AG, Stang Rg, Stoebe TG, Spenler DM. Fixation of porous titanium implants in cortical bone enhance by electrical stimulation. J Biomat Mater Res, 15:37-46, 1981

Cook SD, Barrack RL, Thomas KA, Haddad RJ. Tissue growth into porous primary and revision femoral stems. $J$ Arthroplasty, 6:S37S46, 1991

Cook SD, Ryaby JP, McCbe J, Frey JJ, Heckman JD, Kristiansen TK Acceleration of tibia and distal radius fracture healing in patients who smoke, Clinical Orthopaedics, 337:198-207, 1997.

Cook SD; Baffes GC; Palafox AJ; Wolfe MW; Burgess A Torsional stability of HA-coated and grit-blasted titanium dental implants. $J$ Oral Implantol 1992 18:4 354-65

Craig JG; Jacobson JA; Moed BR Ultrasound of fracture and bone healing. Radiol Clin North Am 1999 37:4 737-51

Dallant P, Meunier A, Christel P, Guillemin G, Sedel L. Quantitation of bone ingrowth into porous implants submitted to pulsed electromagnetic fields. In: Quantitative Characterization and Performance of Porous Implants for Hard Tissue Applications, pg. 286-298, American Society for Testing and Materials, 1987

Dare A; Hachisu R; Yamaguchi A; Yokose S; Yoshiki S; Okano T Effects of ionizing radiation on proliferation and differentiation of osteoblast-like cells. J Dent Res 1997 76:2 658-64

Davis SC; Ovington LG Electrical stimulation and ultrasound in wound healing. Dermatol Clin 1993 11:4 775-81

Dominici JT; Sammon PJ; Drummond JF; Lifland MI; Geissler R; Okazaki K An evaluation of electrodischarged prototype implants in rabbit tibia: a preliminary study. J Oral Implantol 1994 20:4 299306

Donath K, Breuner G A method for the study of undecalcified bone and teeth with attached soft tissues: The stage-scliff (sawing and griding) technique J Oral Pathol. 198211 318-326

Drummond JF; Dominici JT; Sammon PJ; Okazaki K; Geissler R; Lifland MI; Anderson SA; Renshaw W h A light and scanning electron microscopic evaluation of electro-discharge-compacted porous titanium implants in rabbit tibia. J Oral Implantol 1995 21:4 295-303

Duarte LR Estimulação ultra-sônica do calo-ósseo. São Carlos, 1977, 129p Tese (Livre-Docência) - Escola de Engenharia - Universidade de São Paulo - USP

Duarte LR, Xavier CA, Choffie M Review of non-unions treated by pulsed, low-intensity ultrasound, Final Programme of the 20th World Congress SICOT, August 18-23, Amsterdam, pg. 538, 1996. 
Duarte, L.R., Xavier, C.A., Choffie, M., McCabe, J.M.: Review of nonunions treated by pulsed low-intensity ultrasound. Société Internationale de Chirurgie Orthopedique et de Traumatologie (SICOT), P2.110:PDS80, 1996.

Duarte, LR. The stimulation of bone growth by ultrasound, Archives of Orthopaedic and Traumatic Surgery, 101:153-159, 1983.

Duarte, LR. Ultrasonic simulation on fracture healing. Digest of the 11th International Conference on Medical and Biological Engineering, pg. 248, Ottawa, Canada, 1976.

Dyson $M$. Mechanisms involved in therapeutic ultrasound. Physiotherapy (UK) 73:116-120, 1987.

Dyson M; Suckling J: Stimulation of tissue repair by ultrasound: a survey of the mechanisms involved. Physiotherapy, 64 (4): 105-108, 1978.

Dyson, M; Brookes, M Stimulation of bone repair by ultrasound. Ultrassound Med Biol v.8, 61-6, 1982

Einhorn TA: Current concepts review enhancement of fracture healing. J Bone Joint Surg 77 A (6): 940-956, 1995.

Emami A; Larsson A; Petrén Mallmin M; Larsson $S$ Serum bone markers after intramedullary fixed tibial fractures. Clin Orthop 1999 $368220-9$

Enwemeka CS The effects of therapeutic ultrasound on tendon healing. A biomechanical study Am J Phys Med Rehabil 1989 68:6 283-7

Enwemeka CS; Rodriguez O; Mendosa S The biomechanical effects of low-intensity ultrasound on healing tendons. Ultrasound Med Biol 1990 16:8 801-7

Esposito M; Hirsch JM; Lekholm U; Thomsen P Biological factors contributing to failures of osseointegrated oral implants. (I). Success criteria and epidemiology. Eur J Oral Sci 1998 106:1 527-51

Flynn HG: Generation of transient cavities in liquids by microsecond pulses ultrasound: J Accoustic Soc Am, 72: 1926-32, 1982

Frankel VH, Koval KJ, Kummer FJ. Ultrasound Treatment of Tibial Nonunions, American Academy of Orthopaeidc Surgeons, 66th Annual Meeting, February, Anaheim, CA, 1999.

Frankel VH. Results of prescription use of pulse ultrasound therapy in fracture management, Surgical Technology International VII (Orthopaedic Surgery), pg. 389-393, 1998.

Friedenberg ZB; Brighton CT: Bioeletric potentials in bone. $J$ Bone Joint Surg, 48(5): 915-923, 1966

Friedenberg ZB; Brighton CT: Electrical fracture healing. Ann N Y Acad Sci, 238: 564-573, 1974

Fukada, E; Yasuda, I On the piezoelectric effects on collagen. Jap J Appl Phys v.3, 1964

Fukada, E; Yasuda, I On the piezoelectric of bone. J Phys Soc Jap. V.12, 1158-62, 1957.

Gebauer, D., Mayr, E., Orthner, E., Heppenstall, R.B., Frey, J., McCabe, J., and Ryaby, J.P.: Nonunions treated by pulsed low-intensity 
ultrasound. J. Orthop. Trauma, 14:1454, 2000.

Gersten, J.W.: Effect of metallic objects on temperature rises produced in tissue by ultrasound. Amer. J. Phys. Med., 37:75-82, 1988.

Gill PJ; Kernohan G; Mawhinney IN; Mollan RA; Mcllhagger R Investigation of the mechanical properties of bone using ultrasound. Proc Inst Mech Eng 1989 203:1 61-3

Glazer PA, Heilmann MR, Lotz JC, Bradford DS Use of ultrasound in spinal arthrodesis: a rabbit model, Spine, 23(10): 1142-1148, 1998.

Goodship AE; Kenwright J: The influence of the induced micromovement upon the healing of experimental tibial fractures. $J$ Bone Joint Surg 67 B(4): 650-655, 1985

Gottlander M; Albrektsson T; Carlsson LV A histomorphometric study of unthreaded hydroxyapatite-coated and titanium-coated implants in rabbit bone. Int J Oral Maxillofac Implants 1992 7:4 485-90

Hadjiargyrou M; McLeod K; Ryaby JP; Rubin C Enhancement of fracture healing by low intensity ultrasound. Clin Orthop 1998355 216-29

Hadjiargyrou, M., McLeod, K., Halsy, M., Rubin, C.T.: The temporal expression of osteopontin mRNA in the fracture callus is altered by low-intensity ultrasound. J. Bone and Miner. Res., 12:S-290, 1997.

Hans D; Fuerst T; Uffmann M Bone density and quality measurement using ultrasound. Curr Opin Rheumatol 1996 8:4 370-5

Harvey W, Dyson M. Pond JB, Grahame R. The stimulation of protein synthesis in human fibroblasts by therapeutic ultrasound. Rheumatol Rehab: 14:237-242, 1975

Hausman M. Low-intensity ultrasound and antegrade screw fixation in the treatment of complex scaphoid fractures, 58th Annual Meeting of the American Academy of Orthopaedic Surgeosn, January 22-27, San Franscisco, CA, USA, 1991.

Heckman J D, Ryaby JP, , McCabe J, Frey JJ, Kilcoyne RF. Acceleration of Tibial Fracture Healing by Non-Invasive, LowIntensity Pulsed Ultrasound, Journal of Bone and Joint Surgery, 76A (1): 26-34, 1994.

Heckman JD, Sarasohn-Kahn J The economics of treating tibia fractures, Bulletin Hospital for Joint Diseases, 56(1):63-72, 1997.

Heppenstall RB, Frey JJ, Ryaby JP, McCabe JM. Noninvasive Nonunion Treatment by Pulsed Low-Intensity Ultrasound, American Academy of Orthopaeidc Surgeons, 66th Annual Meeting, February, Anaheim, CA, 1999

Heppenstall, R.B., Frey, J.J., Ryaby, J.P., McCabe, J.M.: Noninvasive nonunion treatment by pulsed low-intensity ultrasound. $21^{\text {st }}$ Triennial World Congress Société Internationale de Chirurgie Orthopédique et de Traumatologie, Sydney, Australia, 1999.

Hilário ML, Ultra-Som de Baixa Intensidade na Reparação Tecidual de Úlceras Tróficas de Perna, Dissertação de Mestrado, Interunidades Bioengenharia (EESC/FMRP/IQSC-USP), 1993.

Hoffmann K; Winkler K; el Gammal S; Altmeyer P A wound healing model with sonographic monitoring. Clin Exp Dermatol 1993 18:3 


\section{7-25}

Holden CM; Bernard GW Ultrastructural in vitro characterization of a porous hydroxyapatite bone cell interface. J Oral Implantol 1990 16:2 86-95

Hollender L; Rockler B Radiographic evaluation of osseointegrated implants of the jaws. Experimental study of hte influence of radiographic techniques on the measurement of the relation between the implant and bone. Dentomaxillofac Radiol 1980 9:2 915

Horiuchi M; Ichikawa T; Kanitani HWigianto $\mathbf{R}$; Kawamoto $\mathbf{N}$; Matsumoto $\mathbf{N}$ Pilot-hole preparation for proper implant positioning and the enhancement of bone formation. $J$ Oral Implantol 1995 21:4 318-24

Hunsuck EE Vascular changes in bone repair. J Oral Surg 1969 27:7 572-4

Inui K, Shimazaki A, Nishimura N, Yamano Y. Effect of non-invasive low-intensity ultrasound on distraction osteogenesis in rabbits. 6th Meeting of the International Society for Fracture Repair.

Ito, M., Azuma, Y., Ohta, T. and Keiji, K.: Effects of ultrasound and 1,25dihydroxyvitamin D3 on growth factor secretion in co-cultures of osteoblasts and endothelial cells. Ultrasound in Med. \& Biol., 26(1) 161-166, 2000.

Jackson BA; Schwane JA; Starcher BC Effect of ultrasound therapy on the repair of Achilles tendon injuries in rats. Med Sci Sports Exerc 1991 23:2 171-6

Jingushi, S., Azuma, Y., Ito, M., Harada, Y., Takagi, H., Ohta, T., and Komoriya, K.: Effects of non-invasive pulsed low-intensity ultrasound on rat femoral fracture. Proceedings of the Third World Congress of Biomechanics, 175b, 1998.

Johansson C, Albrektsson T. Integration of screw implants in the rabbit: A 1 -yr follow-up removal torque of titanium implants Int $\mathrm{J}$ Oral Maxillofac Implants. 19872 69-75

Karabuda C; Sandalli P; Yalcin S; Steflik DE; Parr GR Histologic and histomorphometric comparison of immediately placed hydroxyapatite-coated and titanium plasma-sprayed implants: a pilot study in dogs. Int J Oral Maxillofac Implants 1999 14:4 510-5

Kaufman JJ, Popp H, Chiabrera A, Pilla AA. Effect of ultrasound on the electrical impedance of biological cells, Transactions of the 8th Annual Meeting of the Biolectrical Repair and Growth Society, October 9-12, Washington DC, USA pg. 8, 1988.

Kaufman JJ, Popp H, Chiabrera A, Pilla AA. The effect of ultrasound on the electrical impedance of biological cells. IEEE Engineering in Medicine \& Biology Society, 10th Annual International Conference, 1988.

Kirsh A The two-phase implantation method using IMZ intramobile cylinder implants. J. Oral Implantol. 11:197-210, 1983.

Kitchen S; Partridge C: A review of therapeutic ultrasound. Physiotherapy (UK) 76: 593-600, 1990 
Kokubu T; Matsui N; Fujioka H; Tsunoda M; Mizuno K Low intensity pulsed ultrasound exposure increases prostaglandin E2 production via the induction of cyclooxygenase-2 mRNA in mouse osteoblasts. Biochem Biophys Res Commun 1999 256:2 284-7

Krieg MA; Cornuz J; Jacquet AF; Thiébaud D; Burckhardt P Influence of anthropometric parameters and biochemical markers of bone metabolism on quantitative ultrasound of bone in the institutionalized elderly. Osteoporos Int 1998 8:2 115-20

Kristiansen TK, Ryaby JP, McCabe J, Frey JJ, Roe LR LR Accelerated healing of distal radial fractures with the use of specific, lowintensity ultrasound Journal of Bone and Joint Surgery 79-A (7) 9619731997

Kristiansen TK. The effect of low power specifically programmed ultrasound on the healing time of fresh fractures using a Colle's model, Journal of Orthopaedic Trauma, 4 (2): 227-228, 1990.

Lane, J.M., Peterson, M., Ryaby, J.P., and Testa, F.: Ultrasound treatment in 2126 fractures. J. Orthop. Trauma, 13(4),313, 1999.

Lavine LS Piezoeletric effect in bone. Nature 197: 81, 1967

Lehman, J., et al.: Ultrasonic effects as demonstrated in live pigs with surgical metallic implants. Arch. Phys. Med. And Rehabil., 483-488, 1979.

Lemons J; Natiella J Biomaterials, biocompatibility, and peri-implant considerations. Dent Clin North Am 1986 30:1 3-23

Linder L. Osseointegration of metallic implants. 1. Light microscopy in the rabbit Acta Orthop Scand. 198960 129-134

Linkow LI Evolutionary design trends in the mandibular subperiosteal implant. J. Oral Implantol 11:402-38, 1984.

Lotsova, E.I.: Effect of ultrasound on the strength of metal fixing pins for fractures and joint injuries. Mekh. Kompoz Mat., No. 3:548-549, 1979.

Lucchini JP; Aurelle JL; Therin M; Donath K; Becker W A pilot study comparing screw-shaped implants. Surface analysis and histologic evaluation of bone healing. Clin Oral Implants Res 1996 7:4 397-404

Masaya I, Yoshiaki A, Tomohiro O, Keiji K. Effects of ultrasound on the co-culture of osteoblasts with endothelial cells. 6th Meeting of the International Society for Fracture Repair.

Masuda T; Yliheikkilä PK; Felton DA; Cooper LF Generalizations regarding the process and phenomenon of osseointegration. Part I. In vivo studies. Int J Oral Maxillofac Implants 1998 (Jan, 13:1) pags. 17-29

Mayer E, Laule A, Suger G, Claes L, Rüter A. Regenerate maturation aided by low-intensityultra-sound in callus distraction. 6th Meeting of the International Society for Fracture Repair.

Mayer E, Laule J, Suger G, Chir Klinik ZK. Regenerate maturation aided by low-intensity ultrasound in callus distraction. 44th Annual Meeting, Orthopaedic Research Society, March 16-19, New Orleans, Louisiana, USA, pg, 233, 1998.

Mayr, E., Frankel, V.H., Rüter, A.: Ultrasound - an alternative healing 
method for nonunion. Arch. Orthop. Trauma Surg., 120 (1-2):1-8, 2000.

Mayr, E., Laule, A., Suger, G., Claes, L., Rüter, A.: Regenerate maturation aided by low-intensity ultrasound in callus distraction. SIROT 99, publ. By Fruend Publishing House, Ltd., 257-262, 1999.

Mayr, E., Rüter, A.: Fracture healing and ultrasound - Basics and first experience, in Actualités en Biomatériau, ed. by Mainard, D., Merle, M., Delgoutte, J.P., Louis, J.P., Editions Romillat, (3):355-360, 1998.

Mayr, E., Wagner, S., Ecker, M., Rüter, A.: Ultrasound Therapy for Nonunions (Pseudarthrosis) - 3 Case Reports. Der Unfallchirurg, 102:191-196, 1999.

Mayr, E., Wagner, S., Rüter, A: Treatment of Nonunions by Means of Low-Intensity Ultrasound. Der Unfallchirurg, 268:958-962, 1997.

Mcleod, K.: Fracture healing using low-level ultrasound. Presented at the IEEE International Ultrasonic Workshop, Seattle, 1995.

Meani, E., Romano, C.L.: Low-intensity pulsed ultrasound for the treatment of septic nonunion. Third Congress of the European Federation of National Associations of Orthopaedics and Traumatology, Barcelona 1997.

Michaels GC; Carr AB; Larsen PE Effect of prosthetic superstructure accuracy on the osteointegrated implant bone interface. Oral Surg Oral Med Oral Pathol Oral Radiol Endod 1997 83:2 198-205

Misch CE The implant quality scale: a clinical assessment of the health--disease continuum. Oral Health 88:7 15-20, 23-5; quiz 25-6, 1998

Mont MA, Pilla AA, Tenreiro RA, Kaufman JJ, Sadeh A, CamposMarquetti A, Burstein AH, Siffert RS. The effect of ultrasonic stimulation on fresh fracture repair in rabbits, Proceedings of the 33rd Annual Meeting of the Orthopaedic Research Society, January 19-22, San Francisco, CA, USA, 1987.

Mont MA, Pilla AA, Tenreiro RA, Kaufman JJ, Siffert RS. The effects of ultrasonic stimulation on fresh fracture repair in rabbits, Transactions of the Sixth Annual Meeting of the Biolectrical Repair and Growth Society, Utrech, The Netherlands, 1986.

Morgan MJ; James DF Force and moment distributions among osseointegrated dental implants. J Biomech, 1995 Sep, 28(:9) 11039

Mortimer AJ: Dyson M: The effect of therapeutic ultrasound on calcium uptake in fibroblasts. Ultrasound Med. Biol 14:499-506, 1988

Moyen, B., Mainard, D., Azoulai, J.J., Toullec, E.: An effective therapy for non-union- Low-intensity ultrasound. In Proceedings of the Seventh Meeting of the International Society for Fracture Repair in Hong Kong, J. Orthop. Trauma, in press, 2001.

Nolte, P.A., Klein-Nuland, J., Albers, G.H.R/., Marti, R.K., Semeins, C.M., Goei, S.W., Burger, E.H.: Low-intensity ultrasound stimulates in vitro endochondral ossification. Calcif. Tissue Int., 64(suppl 1):S62, 1999. Nolte, P.A., van der Krans, A., Patka, P., Janssen, I.M.C., Ryaby, J.P., and Albers, G.H.R.: Low-intensity pulsed ultrasound in the 
treatment of nonunions. J. of Trauma, 51(4): 12-26, 2001.

Ochi S; Morris HF; Winkler S The influence of implant type, material, coating, diameter, and length on periotest values at second-stage surgery: DICRG interim report no. 4. Dental Implant Clinical Research Group. Implant Dent 1994 3:3 159-62

Parvizi, J., Parpura, V., Greenleaf, J.F., and Bolander, M. E.: Calcium signaling is required for ultrasound stimulated aggrecan synthesis by rat chondracytes. J. Orthop. Res., in press, 2001.

Parvizi, J., Parpura, V., Kinnick, R., Greenleaf, J.F., and Bolander, M. E.: Low-intensity ultrasound increases intracellular concentration of calcium in chondrocytes. Trans Orth. Res. Soc., 43:465, 1997.

Parvizi, J., Wu, C.C., Lewallen, D.G., Greenleaf, J.F., Bolander, M.:. Lowintensity ultrasound stimulates synthesis of proteoglycans in rat chondrocytes by increasing expression of aggrecan gene. J. of Orthop. Res., 17:448-494, 1999.

Pebé P; Barbot R; Trinidad J; Pesquera A; Lucente J; Nishimura R; Nasr $\mathrm{H}$ Countertorque testing and histomorphometric analysis of various implant surfaces in canines: a pilot study. Implant Dent 1997 6:4 259-65

Petrucelli R, Ryaby J, Drapkin J, McCabe. Fracture Healing in Older versus Younger Population Effect of Low-Intensity Ultrasound, Americam Academy of Orthopaedic Surgeons Annual Meeting, March 15-19, Orlando, FL, 2000

Petrucelli R, Ryaby J, Drapkin J, McCabe. Fracture Healing in Older versus Younger Population Effect of Low-Intensity Ultrasound, SICOT, 1999

Petrucelli, R., Oppenheim, W., and Strauss, E.: Fracture healing with non-invasive pulsed low-intensity ultrasound. J. Orthop. Trauma, 13(4):132-133, 1999.

Piattelli A; Corigliano M; Scarano A Microscopical observations of the osseous responses in early loaded human titanium implants: a report of two cases. Biomaterials, $1996 \mathrm{Jul}$, 17:(13, ) 1333-7

Pilla AA, Figueiredo M, Nasser P, Alves JM, Ryaby JT, Klein M, Kaufman JJ, Siffert RS. Acceleration of bone repair by pulsed sine wave ultrasound: animal, clinical and mechanistic studies. In: BRIGHTON, C.T., POLLACK, S.R. eds. Electromagnetics in Medicine and Biology, San Francisco Press, Inc, San Francisco, p.331-341, 1991

Pilla AA, Kahn S, Nasser P, Kaufman JJ, Siffert RS. Low power ultrasound accelerates fracture healing in the rabbit fibula, Transactions of the Eighth Annual Meeting of the Biolectrical Repair and Growth Society, October 9-12, Washington DC, USA pg. 52, 1988.

Pilla AA, Mont MA, Figueiredo M, Nasser P, Kaufman JJ, Lattuga S. Non-Invasive Low-Intensity Pulsed Ultrasound Accelerates Bone Repair. 57th Annual Meeting of the American Academy of Orthopaedic Surgeosn, February 8-12, New Orleans, LA, USA, 1990.

Pilla AA, Mont MA, Nasser PR, Khan AS, Figueiredo M, Kaufman JJ, 
Siffert RS. Non-Invasive Low-Intensity Pulsed Ultrasound Accelerates Bone Healing in the Rabbit, Journal of Orthopaedic Trauma, 4(3):246-253, 1990.

PMA900009, Supplement 6, Summary of Safety and Effectiveness Data for Exogen $2000 \AA 3000^{\mathrm{TM}}$, and SAFHS ${ }^{\circledR}$ for Non-Union Indication, February, 2000.

Rawool NW, Goldberg BB, Forsberg F, Winder AA, Talish RJ, Hume E. Power doppler assessment of vascular changes during fracture treatment with low-intensity ultrasound. Radiological Society of North America, paper \# 1185, November 30 - December 5, 1997.

Reher P; Doan N; Bradnock B; Meghji S; Harris M Effect of ultrasound on the production of IL-8, basic FGF and VEGF. Cytokine 1999 11:6 416-23

Reuter von U; Strempel F; John F; Knoch HG: Modification of bone fracture healing by US in an animal experiment model. $Z$ exp Chir Transplant künstl Organe 17(5) 290-297, 1984

Ricciardi L; Perissinotto A; Dabalà M External callus development on ultrasound and its mechanical correlation. Ital $\mathbf{J}$ Orthop Traumatol 1992 18:2 223-9

Rivero DP, London GC, Skipor AK, Urban RM, Galante JO. Effect of pulsing electromagnetic fields on bone ingrowth in a porous material. Trans Orthop Res Soc, 11:492, 1986

Romano, C., Messina, J., and Meani, E.: Low-intensity ultrasound for the treatment of infected nonunions. In Guarderni di Infezione Osteoarticolari, pp. 83-93. Edited by Agazzi, M., Bergami, P.L., Cicero, G., Gualdrini, G., Mastorillo, G., Meani, M., Mintina, S., and Soranzo, M.L., Milan, Masson Periodical Division, 1999.

Roos J; Sennerby L; Lekholm U; Jemt T; Gröndahl K; Albrektsson T A qualitative and quantitative method for evaluating implant success: a 5-year retrospective analysis of the BrÁnemark implant. Int J Oral Maxillofac Implants 1997 12:4 504-14

Rubin, C., Bolander, M., Ryaby, J.P., Hadjiargyrou, M.: The use of lowintensity ultrasound to accelerate the healing of fractures. J. Bone and Joint Surg., 83-A:, No.2, 259, 270, February, 2000.

Rubin, C.T., et al.: Regulation of bone formation by applied dynamic loads. J. of Bone and Joint Surg., 66-A, 397-402, 1984.

Ryaby JP, Cook SD, Salkeld SL. Acceleration of Spine Fusion with Sonic Accelerated Fracture Healing System, submetido à publicação, 1999.

Ryaby JT, Alves, PD, Schreiber L, Mattew J, Pilla AA. Modulation of adenylate cyclase in bone cell cultures by pulsed ultraosound and mechanical force, Transactions of the 37th Annual Meeting, Orthopaedic Research Society, Anaheim, CA, USA, March, 1991.

Ryaby JT, Bachner EJ, Bendo JA, Dalton PF, Pilla AA. Effect of ultrasound stimulation on mesenchymal cell micromass cultures: calcium uptake studies, Transactions of the Seventh Annual Meeting of the Biolectrical Repair and Growth Society, October 1114, Toronto, Canada, Volume VII, pg. 89, 1987. 
Ryaby JT, Bachner EJ, Bendo JÁ, Dalton PF, Tannenbaum S, Pilla AA. Low-intensity pulsed ultrasound increases calcium incorporation in both differentiating cartilage and bone cells cultures, Transactions of the 35th Annual Meeting of the Orthopaedic Research Society, February 6-9, Las Vegas, Nevada, USA, Volume 14, pg. 15, 1989.

Ryaby JT, Matthew J, Pilla AA. Low-intensity pulsed ultrasound modulates adenylate cyclase activity and transforming growth factor beta synthesis. In: BRIGHTON, C.T., POLLACK, S.R. eds. Electromagnetics in Medicine and Biology, San Francisco Press, Inc, San Francisco, p.95-100, 1991

Ryaby JT, Matthew, Alves PD. Low-intensity pulsed ultrasound affects adenylate cyclase and TGF-* synthesis in osteoblastic cells, Transactions of the 38th Annual Meeting, Orthopaedic Research Society, Washington DC, USA, February, 1992.

Ryaby, Alves PDA, Pilla AA. Clinically effective ultrasound affects second messenger activity in bone cell cultures, Transactions of the 9th Annual Meeting of the Biolectrical Repair and Growth Society, September 17-20, Cleveland, OH, USA, 1989.

Sahin S; Akagawa Y; Wadamoto M; Sato $Y$ The three-dimensional bone interface of an osseointegrated implant. II: A morphometric evaluation after three months of loading. J Prosthet Dent 1996 76:2 176-80

Shafer DM; Rogerson K; Norton L; Bennett J The effect of electrical perturbation on osseointegration of titanium dental implants: a preliminary study. J Oral Maxillofac Surg 1995 53:9 1063-8

Shimazaki, A., Inui, K., Azuma, Y., Nishimura, N. and Yamano, Y.: Lowintensity pulsed ultrasound accelerates bone maturing in distraction osteogenesis in rabbits. J. Bone \& Joint Surg, J. 82-B, 7:1077-1082, 2000

Shimizu T, Zerwekh JE, Videman T, Holmes RE, Mooney V. The effect of pulsing electromagnetic field on bone ingrowth into porous calcium ceramics. . Trans Orthop Res Soc, 12:234, 1987

Silva O, Duarte LR. A proposed mechanism for ultrasonic bone growth stimulation, Transactions of the 9th Annual Meeting of the Biolectrical Repair and Growth Society, September 17-20, Cleveland, OH, USA, 1989.

Skalak R Osseointegration biomechanics. J Oral Implantol 1986 12(:3) pags. 350-356

Skoubo-Kristensen, E., Sommer, J.: Ultrasound influence on internal fixation with a rigid plate in dogs. Arch. Phys. Med. Rehabil., 63, 371-373, 1982.

Spadaro JA, Albanese SA. Application of low-intensity ultrasound to growing bone in rats. Ultrasound in Medicine and Biology, 24(4):567-573, 1998

Strauss E, McCabe JRN Treatment of Jones fractures of the foot with adjunct use of low-intensity pulsed ultrasound stimulation, 65th Annual Meeting of American Academy of Orthopaedic Surgeons, paper \# 402, March 19-23, New Orleans, USA, 1998. 
Strauss E, Oppenheim W, Petrucelli R Acclerated fracture healing with pulsed, low-intensity ultrasound, Final Programme of the 20th World Congress SICOT, August 18-23, Amsterdam, pg. 538-539, 1996.

Strauss E, Ryaby JP, McCabe J. Treatment of Jone's fractures of the foot with adjunctive use of low-intensity ultrasound stimulation. 6th Meeting of the International Society for Fracture Repair.

Strauss E. Adjunct low-intensity ultrasound in Charcot neuroarthropathy. Clinical Orthopaedics and Related Research, 349: 132-138, 1998.

Sun JS; Tsuang YH; Lin FH; Liu HC; Tsai CZ; Chang WH Bone defect healing enhanced by ultrasound stimulation: an in vitro tissue culture model. J Biomed Mater Res 1999 46:2 253-61

Tanzer M, Harvey E, Kay A, Morton P, Bobyn JD. The effect of noninvasive low intensity ultrasound on bone growth into porous coated implants. Journal of Orthopaedic Research, 14:901-906, 1996

Tanzer M, Harvey E, Kay A, Morton P, Bobyn JD. The effect of noninvasive low intensity ultrasound on bone growth into porous coated implants. 41st Annual Meeting, Orthopaedic Research Society, February 13-16, Orlando, FL, USA, 1995.

Teixeira ER; Sato Y; Akagawa Y; Shindoi N A comparative evaluation of mandibular finite element models with different lengths and elements for implant biomechanics. J Oral Rehabil, 1998 Apr, 25:(4) 299-303

Ter Haar G: Basic physics on therapeutic ultrasound. Physiotherapy 73 (3): 110-113; 1987

Vicente MFR, Alves JM, Gabrielli MAC, Roslindo EB. Efeitos da Estimulação Ultra-Sônica de Baixa Intensidade em Fraturas BucoMaxilo-Faciais - Estudo Experimental em Coelhos. $5^{\circ}$ Congresso Paulista de Cirurgia e Traumatologia Buco-Maxilo-Facial, SantosSP, Outubro, 2000

Vicente MFR, Alves JM, Gabrielli MAC, Roslindo EB. Efeitos da Estimulação Ultra-Sônica de Baixa Intensidade em Osteotomias de Mandibula - Estudo Experimental em Coelhos. Dissertação de Mestrado, Interunidades Bioengenharia (EESC/FMRP/IQSC-USP), 2000.

von Arx T; Hardt N; Wallkamm B The TIME technique: a new method for localized alveolar ridge augmentation prior to placement of dental implants. Int J Oral Maxillofac Implants 1996 11:3 387-94

Wallace AL; Draper ER; Strachan RK; McCarthy ID; Hughes SP The vascular response to fracture micromovement. Clin Orthop; (301):281-90, 1994 Apr.

Wallace, S Beyond Osseointegration; A periodontal perspective. Irvine CA, Interpore International, 1990.

Wang S, Lewallen DG, Bolander ME, Chao EYS, Ilstrup DM, Greeeleaf JF Low-intensity ultrasound treatment increases strength in a rat femoral fracture model Journal of Orthopaedic Research, 1994 12(1) pags. $40--47$ 
Weistein AM, Klawitter JJ, Cleveland TW. Electrical stimulation of bone growth into porous A1203. J Biomed Mat Res, 10:231-247, 1976

Williams KR; Williams AD Impulse response of a dental implant in bone by numerical analysis. Biomaterials 1997 18(10) pags. 715-719

Wiltink-A; Nijweide-PJ; Oosterbaan-WA; Hekkenberg-RT; Helders-PJ: Effect of therapeutic ultrasound on endochondral ossification. Ultrasound-Med-Biol. 21(1): 121-7,1995

Xavier CAM, Duarte LR, Paulin JBP. Treatment of non-unions by ultrasonic stimulation: First Clinical Application, Proceedings of the 54th Annual Meeting of the American Academy of Orthopaedic Surgeons, San Francisco, CA, USA, 1987.

Xavier, CM Duarte, LR. Estimulação ultra-sônica do calo ósseo, Revista Brasileira de Ortopedia, 18:73-80, 1983.

Yang KH; Parvizi J; Wang SJ; Lewallen DG; Kinnick RR; Greenleaf JF; Bolander ME Exposure to low-intensity ultrasound increases aggrecan gene expression in a rat femur fracture model. $J$ Orthop Res 1996 14:5 802-9

Young JW; Kostrubiak IS; Resnik CS; Paley D Sonographic evaluation of bone production at the distraction site in Ilizarov limblengthening procedures. AJR Am J Roentgenol 1990 154:1 125-8

Young SR; Dyson M Effect of therapeutic ultrasound on the healing of full-thickness excised skin lesions. Ultrasonics 1990 28:3 175-80

Young SR; Dyson $M$ The effect of therapeutic ultrasound on angiogenesis. Ultrasound Med Biol 1990 16:3 261-9

Ziskin, M. C.: Report on the Safety of the Therasonics Medical Systems (Exogen. Inc.) SAFHS Unit, Model 2A. PMA P900009, Vol.3,VI.A.,234, 1989.

Zorlu Ü; Tercan M; Özyazgan I; Taskan I; Kardas Y; Balkar F; Öztürk F Comparative study of the effect of ultrasound and electrostimulation on bone healing in rats. Am J Phys Med Rehabil 77 (5):427-432, 1998 